POINTING TO INCLINATIONS:

ALBERTUS MAGNUS' PHYSIOGNOMY AS A

SCIENTIFIC AND THEOLOGICAL NEXUS

\author{
A Dissertation \\ presented to \\ the Faculty of the Graduate School \\ at the University of Missouri-Columbia \\ In Partial Fulfillment \\ of the Requirements for the Degree \\ Doctor of Philosophy \\ by \\ HEATHER THORNTON MCRAE \\ Dr. A. Mark Smith, Dissertation Supervisor \\ May 2018
}


(C) Copyright by Heather Thornton McRae 2018

All Rights Reserved 
The undersigned, appointed by the dean of the Office of Graduate Studies, have examined the thesis entitled

\section{POINTING TO INCLINATIONS: ALBERTUS MAGNUS' \\ PHYSIOGNOMY AS A SCIENTIFIC AND THEOLOGICAL NEXUS}

presented by Heather Thornton McRae

a candidate for the degree of doctor of philosophy

and hereby certify that, in their opinion, it is worthy of acceptance.

\begin{tabular}{c}
\hline Professor A. Mark Smith \\
\hline Professor Lois Huneycutt \\
\hline Professor Russell Zguta \\
\hline Professor Lawrence Okamura \\
\hline Professor Rabia
\end{tabular}




\section{DEDICATION}

This dissertation is dedicated to my husband James and my son Jack. My head may be in the Middle Ages, but my heart is always with them. 


\section{ACKNOWLEDGEMENTS}

This dissertation would not have been possible without the support of my chair,
A. Mark Smith, and my other committee members. The time necessary to read and
discuss my work is in and of itself worthy of praise, but the level encouragement and
constructive criticism I received is above and beyond the expected. I would also like to thank my fellow graduate students, particularly those in medieval history who read my work at various stages in writing groups. 
TABLE OF CONTENTS

ACKNOWLEDGEMENTS.................................................................................

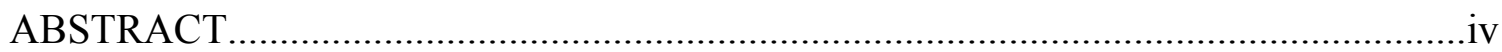

CHAPTER ONE: Introduction...........................................................................

CHAPTER TWO: From Omen to Medicalized Scientia:

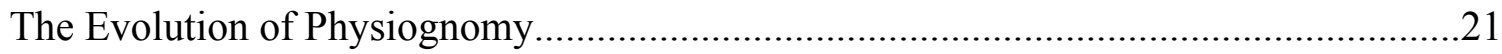

CHAPTER THREE: Medicine and the Medicalization of Physiognomy.......................89

CHAPTER FOUR: Theories of the Soul and Their Roles in Medieval Physiognomy...121

CHAPTER FIVE: Albertus's Physiognomy and Physiognomy

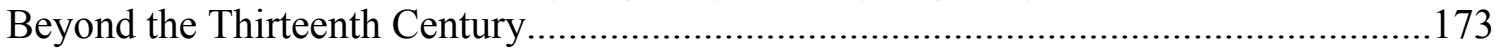

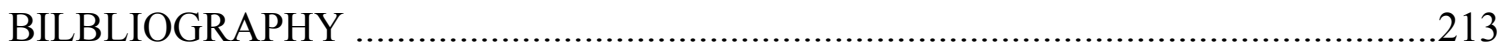

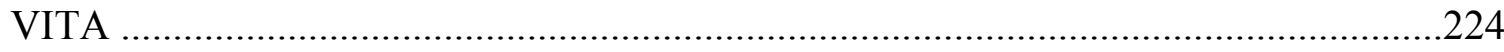




\title{
POINTING TO INCLINATIONS: ALBERTUS MAGNUS' PHYSIOGNOMY AS A SCIENTIFIC AND THEOLOGICAL NEXUS
}

Heather Thornton McRae

Dr. A. Mark Smith, Dissertation Supervisor

\begin{abstract}
This dissertation explores the physiognomy of Albertus Magnus, which is contained within his commentary on De animalibus, the three works on animals by Aristotle. This physiognomy provides an opportunity to demonstrate the medieval intellectual world view that the body and soul were connected, both theologically and medically. Albertus Magnus and his physiognomy also exemplify the reintroduction of physiognomy into Latin Christendom in the twelfth and thirteenth centuries through deep textual connections in physiognomy, medicine, and theories of the soul to the classical Mediterranean through the intermediary of the Islamic world. Physiognomies like that of Albertus Magnus also contribute to ideas of what constitutes a medieval scientia by building upon past scholarship on astrology, hagiography, and other aspects of the premodern world that have largely been rejected until recent decades.
\end{abstract}




\section{CHAPTER ONE: Introduction}

In or near the year 1260 Albertus Magnus (c. 1200-1280) repeated in his writings an anecdote at least fifteen centuries old:

[Aristotle] tells us that a painted, well-executed portrait of Hippocrates was brought by his students to Phylemon, a superior physiognomist.

When he had inspected the picture, comparing member with member, and had noted the force of the indications, he announced that this was a man given to pleasure, a liar, and very fond of intercourse. The students became indignant and upbraided Phylemon because he had proclaimed such things about the best of men. They then brought this judgment back to Hippocrates himself who confessed that Phylemon had judged correctly. But, he said, he had overcome the desires of this heart through love of philosophy and uprightness and had acquired through study what had been denied in his nature. ${ }^{1}$

\footnotetext{
${ }^{1}$ Albertus Magnus. De animalibus. English translation in Albertus Magnus On Animals, Kenneth F. Kitchell Jr and Irven Michael Resnick, eds. (Baltimore: Johns Hopkins Press, 1999), 93. Latin in De animalibus, Hermann Stadler, ed. (Münster: Aschendorfsche Verlagsbuchhandlung, 1916-1920), 46. Quam vere tamen sint inclinationes sic pronosticatae, ostendit Aristoteles, qui narrat, quod a discipulis Ypocratis figura Ypocratis picta et optirne expressa portata fuit Phylemoni excellenti physonomo, quamcum inspexisset et comparasset membrum membro et vim signorum advertisset, pronuntiavit de ipso, quod esset vir luxuriosus et deceptor, amans coitum. Illis autem indignantibus et culpantibus Phylemonem, quod de o'ptimo viro talia pronuntiasset, pertulerunt tandem indicium ad ipsum Ypocratem, et confessus est Phylemonemquidem veruni iudicasse: sed ex amore philosophiae et honestatis dixit se concupiscentias cordis sui vicisse et accepisse per studium quod negatum fuerat naturae.
} 
This story appeared in Albertus's commentary on Aristotle's De animalibus. While Albertus's commentary on Aristotle's combined three works on animals is entirely in keeping with both Albertus's intellectual efforts and the thirteenth-century Latin intellectual activity in general, within Albertus's De animalibus are frequent chapters and asides dedicated to the ancient science of physiognomy, something that at first seems to strike a discordant note within this scholarly milieu of theology and natural philosophy, or science.

Albertus Magnus, or Albert the Great, is often best known today as St. Thomas Aquinas's teacher. However, during his lifetime and until the Counter-Reformation Albertus was by far the better known of the two. Roger Bacon refers to him as the intellectual who had completed and composed philosophy in the Latin tongue and points out that he was an authority during his own lifetime. ${ }^{2}$ This is an honor that, according to Bacon, no man had ever had before. ${ }^{3}$

Despite his eventual fame, Albertus's earliest years, like those of many medieval figures, are quite hazy. Scholars have put forth estimations of his birth year from 1193 to 1207 , but the scholarly consensus is that he was probably born in or near Lauingen (Bavaria) in $1200 .^{4}$ The next glimpse of Albertus tells us that his early education was in

\footnotetext{
${ }^{2}$ Roger Bacon, Opus Tertium, in Opera Quaedam Hactenus Inedita, vol. 1, ed. J.S. Brewer (London: Longman, Green Longman and Roberts, 1859), 30. Bacon does not mention Albertus by name, but the scholarly consensus does not doubt that Bacon is referring to the Dominican scholar. See Resnick's introduction to Albertus Magnus On Animals.

${ }^{3}$ Bacon, Opus Tertium, 30. The Latin reads nunquam homo habuit.

${ }^{4}$ For the debate on the birth date, see Kovach, Francis J. and Robert W. Shahan, eds. Albert the Great: Commemorative Essays, (Norman, Oklahoma: University of Oklahoma
} 
Italy. The only firm date is that he was in Lombardy at Christmas in 1222 because he mentions his presence there during the earthquakes that occurred that year. ${ }^{5}$ While scholars debate where he formally entered the young Dominican order, scholars do agree that it was in Padua during this Italian period that he first met Dominicans, and either joined the order there or upon his arrival in Cologne in 1229 or 1230 after the order sent him there. ${ }^{6}$ By 1233 Albertus was appointed as a lector, and the Dominicans moved him around Germany often, from a priory in Hildesheim to Vriburgo (perhaps Freiburg im Breisgau), Regensburg, and Strasbourg. ${ }^{7}$

Someone in the Dominican order must have seen the potential in Albertus because sometime before 1244 he was sent to Paris to study theology, where he became a Master in Theology in 1245, and taught as a Regent Master until 1248. ${ }^{8}$ Albertus's intellectual career continued in 1248 when he was called to oversee the Dominican studium generale

Press, 1980), viii. Scholars such as Emil Michael and Hieronymus Wilms argue for the 1193 date, while others such as J.A. Endres and P. Mandonnet argue for the 1207 date.

${ }^{5}$ For more on the evidence of his early Italian years, see the introduction to Albertus and Thomas: Selected Writings, trans. ed. and intro. by Simon Tugwell, O.P. and preface Leonard E. Boyle, O.P. (New York: Paulist Press, 1988), 6.

${ }^{6}$ See Albertus and Thomas, 4, 6-7. Padua was also likely the beginnings of his formal university education, but, as Nancy Siraisi and others have pointed out, it was only one of the first stages of his intellectual development, unlike those few who try to pinpoint his scientific foundations to only Italy. See N. G. Siraisi, "The Medical Learning of Albertus," in James A. Weisheipl, ed., Albertus Magnus and the Sciences: Commemorative Essays (Toronto: Pontifical Institute of Medieval Studies, 1980), 388.

${ }^{7}$ See Albertus and Thomas, 7-8.

${ }^{8}$ Again, scholars differ on the exact date of Albertus's arrival in Paris, but the range is from 1240 to 1244, giving Albertus somewhere between four and eight years in Paris. Kitchell and Resnick offer the earlier date of 1240. See Kitchell, 11. It is also worth noting that the title of Master was the highest level at the time. 
in Cologne. However, this intellectual focus did not last, as the Dominicans began giving him more administrative positions all over Germany, using his other skills to help run the order. In 1254 he was elected Prior Provincial of the German Dominicans at Worms, charging him with overseeing 36 priories and a similar number of monasteries of nuns. Part of Albertus's duties as prior included visiting all of the priories on foot, while begging, and without the luxury of a private room. ${ }^{9}$ When he was released from the duties of his provincial office in 1257, it seemed that Albertus would be able to return to his post as lector at Cologne, but on January 5, 1260, Pope Alexander IV (r. 1254-61) appointed him Bishop of Regensburg, and he took possession of his see on Maundy Thursday (March 30) of the same year. ${ }^{10}$ Pope Urban IV (r. 1261-63) allowed Albertus to resign in the spring of 1262 but still required Albertus to serve as a special envoy in Germany, preaching and raising money for crusades. He was finally allowed to retire to Cologne's Holy Cross cloister in 1269 or 70 , where he died on November $15,1280{ }^{11}$

Somehow in the midst of his Dominican duties, between 1250 and 1270 Albertus was able to produce a set of commentaries on the Aristotelian corpus. It was during his years in Paris that Albertus encountered the flood of new translations of Aristotle (384322 BCE) that would define his life's intellectual work. This new corpus added to what he already knew of Aristotle's writings, as is shown in Albertus' first work, De natura boni, which references the Aristotle known in the early Middle Ages and Latin authors

\footnotetext{
${ }^{9}$ See Albertus and Thomas, 12.

${ }^{10}$ See Albertus and Thomas, 15-19.

${ }^{11}$ For more, see Kitchell, 3, 15.
} 
such as Cicero (106-43 BCE), Seneca (4 BCE-65 CE), and Augustine (354-430). ${ }^{12}$ This new Aristotelian material gave Albertus the chance to comment upon virtually the entire surviving Aristotelian corpus. This commentary on scientia naturalis, Albertus writes in his Physica commentary, was at the behest of his Dominican brethren, who had been asking him to write such commentaries many times, for many years. Now, it was his intention to satisfy their demands. ${ }^{13}$

Albertus was particularly suited to undertake such an ambitious project because he was so incredibly widely read, a true polymath of his age. These texts included not just the religious sources expected of a churchman, but a wide array of scientific sources as well. This acquaintance with a daunting number of sources is made clear in his writings. For instance, in discussing optics in De sensu, he cites Alhacen (Hasan Ibn alHaytham, c.965-1040) and al-Kindī (c.803-873). ${ }^{14}$ For a second example, on one page of De caelo et mundo Albertus cites Pythagoras (c. 570-495 BCE), Hermes Trismegistus, Averroes (Ibn Rushd, 1126-1198), and Ptolemy (100-170), including the Almagest specifically. ${ }^{15}$

His set of commentaries includes Aristotle's works on animals, known collectively as De animalibus. The first books of Albertus's De animalibus are dated to

\footnotetext{
${ }^{12}$ For more, see Albertus and Thomas, 8.

${ }^{13}$ Albertus, Physica, Opera omnia, vol. 3, ed. Borgnet (Paris, 1890), 1. Intentio nostra in scientia naturali est satisfacere pro nostra possibilitate fratribus Ordinis nostri, nos rogantibus ex pluribus jam praecendentibus annis.

${ }^{14}$ A Mark Smith, From Sight to Light: The Passage From Ancient To Modern Optics (University of Chicago Press, 2014), 256.

${ }^{15}$ Albertus, De caelo, Opera omnia, vol. 4, ed. Borgnet (Paris, 1890), 12.
} 
1256-1260, the short window between his roles as provincial prior and Bishop of Regensburg. The later parts of the commentary were probably finished sometime after he was released from his bishopric. ${ }^{16}$

Albertus's De animalibus is a lengthy text making up ten books, twenty-seven tracts, and countless chapters. It addresses the content of the three Aristotelian works on animals, namely on the history, the gaits, and the parts of animals. The majority of $D e$ animalibus is unsurprisingly dedicated to animal members (body parts), generation, and behavior. Within the first few books lies a discussion of man's parts, generation, and general physiology, positioned first because of man's preeminence among animals. In the bodies of many of the chapters devoted to the anatomy and physiology of individual body parts or groups of parts, Albertus chose to include physiognomy. This makes De animalibus one of the earliest medieval commentaries on ancient Greek and Arabic physiognomic ideas, though it must be pieced together from multiple chapters on human anatomy and physiology along with a few chapters that include physiognomy in the title.

How, then, did a subject largely unknown in Latin Christendom before the thirteenth century find a place in the work of one of the most important scholastic minds of that same century? Where did it fit into the Middle Ages? In order to truly evaluate how physiognomy found a place and functioned in the thirteenth-century intellectual milieu it is important to jettison our modern scientific paradigm as best we can, a tall order indeed. But in studying the Middle Ages we have made ourselves comfortable as scholars looking at genres of writing such as hagiography and other miracle stories that defy modern credulity. Indeed, physiognomy actually makes more sense than miracles

\footnotetext{
${ }^{16}$ Kitchell agrees with these dates. See On Animals, 35-40.
} 
within the context of the Middle Ages: miracles defy logic by their very existence (think of the free-floating accidents of transubstantiation). In other words, they are miracles because they defy natural explanation. Physiognomy, on the other hand, works with most manifestations of ancient Greek and medieval Islamic science. Instead of dismissing it as “occult," we should endeavor to understand it. After all, if occult is taken to mean not just the literal "covered up" of its Latin root, and instead takes on its modern meaning of something supernatural, mystical, or magical, then physiognomy is demonstrably not occult: it is not beyond nature, but innately of it, not mystical but instead quite explainable. Instead, thinkers of the Middle Ages gave credence to physiognomy, not because it was beyond nature, but because it made sense within the framework of medieval and classical cosmography, theology, and science.

Physiognomy, the belief that an educated practitioner could judge something about the subject's internal, innate character, or soul, based upon physical, outward signs, seems out of place to twenty-first-century minds. Yet, with its medieval manifestation having roots in both medicine and the theological and psychological theories of the soul, physiognomy was very much integrated with the world of thirteenth-century scholasticism and the newly vibrant universities of Europe.

Modern discomfort with "unscientific" sciences is nothing new, as the career of Richard Lemay attests. His Abu Ma'shar and Latin Aristotelianism attempted to remove the stigma from studying the scientia of medieval astrology. ${ }^{17}$ In doing so, Lemay showed just how central the subject was to the development of Western physics or natural

\footnotetext{
${ }^{17}$ Richard Lemay, Abu Ma'shar And Latin Aristotelianism In The Twelfth Century: The Recovery Of Aristotle's Natural Philosophy Through Arabic Astrology, (Beirut: Catholic Press, 1962).
} 
philosophy and the recovery of Aristotle, which form the roots of modern western science. Physiognomy is a similarly "unscientific" science, with many of the same connections and emphases that Lemay demonstrated for astrology. First, physiognomy, like astrology, is from the ancient world, modified in the early Islamic world, and transmitted through the translation movement of Arabic and Greek works into Latin in the twelfth century. Second, the physiognomic texts were, like their astrological counterparts, then read, digested, and commented upon in the new university centers of learning in the thirteenth century before taking on renewed life in original works that eventually entered the vernaculars and less scholarly educated milieus.

Yet, medieval physiognomy remains a problematic, or at least odd, subject of intellectual history, resulting in relatively few books or articles with the science as the main subject. This is, perhaps, for a number of reasons. One is that some of the most important physiognomic texts are Pseudo-Aristotelian, attributed to Aristotle for almost the entirety of the Middle Ages. Yet, this falsely attributed authorship gave physiognomy a great deal of authority and weight. Does not the very fact that intelligent men believed for more than a millennium that physiognomy was a subject worthy of "The Philosopher" say something about both medieval science and physiognomy itself? These are connections and contexts that can and should be explored. How does physiognomy fit in with medieval subjects that modern intellectuals are much more comfortable with?

In terms of medicine, a close examination of ancient and medieval texts available to Albertus reveals just how compatible they were with physiognomy. The humoral complexions described by the Hippocratic corpus, Galen, Constantine the African, and so many other ancient and medieval medical texts lend themselves to the basic premise of a 
deep, inalienable connection between the soul (anima) and the body (corpus). Medicine played a starring role in medieval physiognomy, including the ancient and Islamic roots of the Western medical tradition.

Medicine, however, provides only part of the basis upon which physiognomy was accepted as legitimate within the Latin Christian medieval worldview, showing how complexions and passions can allow the soul to influence the body and body the soul. An examination of the soul, on the other hand, can reveal why physiognomy can be both explained and permissible. Medieval conceptions of the soul have roots similar to those of medieval medicine, with the addition of early Christian tradition. Thirteenth-century medieval theology was in the midst of one of the world's great periods of synthesis, as Europe's best minds struggled to reconcile Christian theology with the newly translated and rediscovered Arabic and Ancient works, which were read, debated, and commented upon. ${ }^{18}$ It was within this context, from these ancient and medieval thinkers that the

${ }^{18}$ The discovered and rediscovered works of Aristotle and Islamic theologians such as Avicenna and Averroes were some of the authors whose texts provided rich food for thought and, at the same time, also offered real dilemmas in the form of some points that were in clear opposition to existing medieval Christian theology. However, the main impetus for the translation movements was not theology, but scientific knowledge, particularly Greek and Hellenistic science such as Ptolemy's Algmagest. For instance, one of the most prolific translators was the Italian Gerard of Cremona, a member of the so-called Toledo school of translators. Edward Grant's A Source Book in Medieval Science, (Cambridge: Harvard Univ. Pr.), 35-8, contains a list of Gerard's translations that shows the breadth of the works that he translated. However, Gerard was also one of the translators for the first translation of the Qu'ran into Latin, under the patronage of Peter the Venerable, Abbot of Cluny. For scholarship on the translations movements of the twelfth century, see the work of Charles Burnett, particularly Arabic Into Latin In The Middle Ages : The Translators And Their Intellectual And Social Context (Farnham, England: Ashgate/Variorum, 2009). One of the early scholars in this subject was MarieThérèse d'Alverny, particularly her La Transmission Des Textes Philosophiques Scientifiques Au Moyen Age, ed. Charles Burnett (Hampshire, England: Aldershot/Variorum, 1994). For the influence on the Iberian translations on Castile, see 
justifications can be found for why physiognomy was considered possible, why it was considered a true science. The addition of Augustinian ideas of the will to Aristotle's exploration of the anima combined in medieval theology to explain physiognomy through discussions of original sin. Humans have the possibility of actualization through contemplation of God and his mercy, but original sin, if not overcome, allows the body to influence the souls adversely, a tendency that could be read by physiognomers on a human subject. It is this physical mark of original sin that medieval thinkers likely read into the famous description of Hippocrates by "Phylemon." Being "given to pleasure, a liar, and very fond of intercourse" would count as indications of sinfulness while "love of philosophy and uprightness and had acquired through study" are all indications of an inclination toward propriety and goodness. This neatly circumscribed place for physiognomy, at the intersection between medicine and theology in medieval thought, defies its classification as an occult science.

Despite the fact that physiognomy, like any subject, is best evaluated from within its proper historical context, the history of science has been reluctant to take on such work until fairly recently. Physiognomy's place in the historiography of science has been largely ignored until the last decade or so because it, admittedly, does not fit most definitions of modern science. It is also the victim of the discipline's preoccupation with the question of what the seventeenth century actually represents: Is it a Scientific Revolution? And if so, what is "radical and pervasive" about it, as David Lindberg has

Robert I. Burns, S.J., ed., Alfonso X the Learned of Castile and His Thirteenth-Century Renaissance (Philadelphia: University of Pennsylvania Press, 1990). 
asked. ${ }^{19}$ In other words, does the seventeenth century signify a significant break with the Middle Ages, or is there more of an argument for continuity? Medieval science has been long caught up in this debate.

Lindberg, himself, is a measured and moderate proponent of the continuity of science from the Middle Ages, through the Renaissance, and into the Modern Era. He lays out the historiography of the question concisely. The argument for a radical break come, unsurprisingly, from the likes of Francis Bacon (1561-1626), who argued that the Middle Ages were "unprosperous" times when both Muslim and Christian authors were more interested in the quantity than the quality of their work. ${ }^{20}$ Voltaire (1694-1778) soon followed with even less evenhanded accusations, calling the Middle Ages a time of "general decay and degeneracy." 21 As Lindberg points out, matters only got worse in the nineteenth century, with Jacob Burckhardt (1818-97) claiming that the Middle Ages "spared themselves the trouble of induction and free inquiry." 22 Andrew Dickson White (1832-1918) only added to this characterization by offering a rather Gibbonesque critique of the history of science in the Middle Ages, blaming all its ills on Christianity, which, he

${ }^{19}$ David C. Lindberg, The Beginnings of Western Science: The European Scientific Tradition in Philosophical, Religious, and Institutional Context, 600 B.C. to A.D. 1450. Chicago: University of Chicago Press, 2007, 361.

${ }^{20}$ Lindberg quotes Francis Bacon's New Organon, 1620, 4:77.

${ }^{21}$ Lindberg quotes Voltaire, Works, trans. T. Smollet and T. Francklin, et. al., 39 vols. (London: J. Newberry, 1761-74), 1:82, 359-60.

${ }^{22}$ Jacob Burckhardt, The Civilization of the Renaissance in Italy, trans. S.G.C. Middlemore, (London: S. Sonnenschein, 1904), 492. However, on the same page Burckhardt is sure to make Italy the exception to the rule, noting that they had knowledge and admiration for the best of the Islamic world, for example, "from the time of the Crusades." 
claimed, made the search for truth unwelcome because of the poisonous intellectual atmosphere the religion created. ${ }^{23}$

However, at the turn of the twentieth century there was a "pro-medieval counterattack. ${ }^{24}$ This is often thought to begin with the work of Pierre Duhem (18611916), who, in his search for the foundations of statics, found the work of fourteenthcentury mathematicians. These Paris and Oxford men, he thought, had prepared the way for modern science. ${ }^{25}$ Despite accusations from his detractors of "Whiggism," or cherrypicking the most modern ideas from the Middle Ages, Duhem prepared the way for the history of medieval science, making it respectable by arguing that the work of Copernicus, Galileo, Kepler, Descartes, and Newton was but a continuation of the science of the Middle Ages. ${ }^{26}$ After World War I, scholars like Charles Homer Haskins (18701937) and Lynn Thorndike (1882-1965) continued work in the same vein in order to show that modern science is in some sense a continuation of medieval science. However, it was the post-World-War-II florescence of scholarship that saw the idea and the debate take fire. For instance, the lectures of Herbert Butterfield (1900-1979) for the History of Science Committee in 1948 argued for the revolutionary quality of the seventeenth century, seeing only the advent of Christianity as its equal in influence. But in the following decades, Lindberg argues, the debate between continuity and revolution

${ }^{23}$ See Lindberg, Beginnings of Western Science, 358.

${ }^{24}$ Lindberg, Beginnings of Western Science, 358.

${ }^{25}$ Lindberg, Beginnings of Western Science, 358.

${ }^{26}$ Edward Grant, The Foundations of Modern Science in the Middle Ages: Their Religious, Institutional, and Intellectual Contexts (Cambridge University Press, 1996), xi-xii. 
lessened in its intensity. No scholar today would dare to put forth the views of a Bacon, Voltaire, or White. But there is still a debate between those, like Lindberg, who believe in a moderate continuity, and those who continue to see the seventeenth century as a firm demarcation between "us" and "them," a view that persists in textbooks and the general public. This is in no small part due to the success of Thomas Kuhn's The Structure of Scientific Revolutions (1962), which spread ideas of the progress of science much further than even he intended. Beginning in the 1970s, the latest identifiable trends dealing with the question of possible continuity are specialization and contextualization. ${ }^{27}$

Alexander Koyré (1892-1964), represents the other side of the issue. Koyré, in his philosophical approach to the history of science, saw in the seventeenth century something transformative. This transformation was exemplified for him by the age's astronomy, what he saw as the "destruction of the cosmos and the geometrization of space," in other words, the world from a "finite, well-ordered whole" to a universe that could be indefinite of infinite, "unified only by the identity of its ultimate.,"28

However, many historians of medieval science, such as Edward Grant, moved at the end of the twentieth century from Koyré's point of view to something a bit closer to Lindberg's. Grant, in his The Foundations of Modern Science in the Middle Ages: Their Religious, Institutional, and Intellectual Contexts (1996), reversed many of the opinions he had earlier put forth in his Physical Science in the Middle Ages (1977). In two decades his "sense of the medieval achievement in science and natural philosophy and ...

${ }^{27}$ Lindberg, David C. and Robert S. Westman, eds. Reappraisals of the Scientific Revolution (Cambridge University Press, 1990), "Introduction," xviii-xix.

${ }^{28}$ Alexandre Koyré, From the Closed World to the Infinite Universe (Baltimore: Johns Hopkins University Press, 1957), viii. 
understanding of the intellectual environment that produced it, as well as ... perception of the relationship between medieval science and the Scientific Revolution, had all been fundamentally transformed." 29

In terms of the continuity debate, physiognomy's place is a bit complicated. On the one hand, it offers a great argument for continuity rather than revolution, with a wealth of early book publishing on the topic in Europe and continued popularity for centuries. The new print culture helped to widely circulate works of physiognomy known in the Middle Ages. Meanwhile, contemporary authors wrote new treatises, like the multi-volume De humana physiognomonia, by Giambattista Della Porta (1535-1615), first published in $1586 .^{30}$ The new and old works of physiognomy in print, therefore, far outnumber the known copies of physiognomy manuscripts in the Middle Ages.

Additionally, these manuscripts were often translated into the vernacular and reprinted over the years, adding to the availability of physiognomic knowledge in Europe. Clearly, then physiognomy became better known rather than forgotten in the seventeenth and following centuries.

On the other hand, to return to the idea of modern definitions of science within the idea of continuity, physiognomy absolutely does not conform to this idea. For instance, if science is recognized not by methodology or epistemology, but by a "particular set of beliefs about nature - more or less the current teachings of physics, chemistry, biology, [and] geology," then physiognomy, like alchemy and astrology is not a modern science. ${ }^{31}$

\footnotetext{
${ }^{29}$ Grant, The Foundations of Modern Science, xi.

${ }^{30}$ More will be said on this in the concluding chapter.

${ }^{31}$ Lindberg, Beginnings of Western Science, 2.
} 
This conclusion supports the idea that there was a scientific revolution at some point, dispensing with belief in what we now call pseudo-sciences. Additionally, physiognomy, which was discussed almost exclusively in the intellectual worlds of the new universities and tangential institutions in the twelfth and thirteenth centuries, changed audiences in a significant way in the seventeenth century. The same printing presses and translations that shared physiognomy with literate Europe and its networks also moved the subject out of the exclusive purview of theologians and scholars. This movement of interest from one audience to another was augmented by the fact that the scholars best known in later ages, such as Albertus's student St. Thomas Aquinas, did not include physiognomy in their works. But perhaps the most important part of this examination of the place of physiognomy is to remind us to, at least in part, judge it from a standpoint of historical empathy, to remember that it comes from a time when things like the soul shaping the body and therefore being able to be read made not just sense, but orderly, natural sense.

To further complicate the question, there is the problematic nature of the dichotomy of continuity/discontinuity within the history of science. Such a binary can lead to conclusions more about teleological minutiae than conclusions that offer meaningful insights into the Middle Ages or our current perception of them.

Where, then, does physiognomy fit into the history of science beyond the continuity question, when it is rarely mentioned in comparison to other subjects? Perhaps the answer is not to focus on modern ideas of science that reject it, or even on the mainstream modern history of science, which was so slow to embrace physiognomy, astrology, alchemy and other pseudo-sciences or occult sciences. After all, the Middle Ages had no concept of a pseudo-science. Instead, let us return to physiognomy in the 
context of the twelfth and thirteenth centuries, specifically to the way that the intellectuals of the Middle Ages thought about science and other subjects.

The division of disciplines in the Middle Ages began as a two-tiered system, forming the trivium (grammar, logic, rhetoric) and then the quadrivium (arithmetic, geometry, music, astronomy). To the modern eye, the obvious science in this plan is astronomy, though the rest of the quadrivium had roots in mathematics as well. Prior to the twelfth century, Latin Christendom did not have much Aristotle, but enough to divide the sciences into theoretical ("knowledge for its own sake") and practical ("knowledge that will serve as a guide to conduct and hence embrace ethics and politics"). ${ }^{32}$ An example of how an intellectual of this era would categorize sciences is found in the Didascalicon, which was written by Hugh of St. Victor (1096-1141), in the 1120s. Using the standard sources of the early Middle Ages, he relied upon the likes of St. Augustine and Boethius (480-524) to create a "classification of the sciences" for his work. In Chapter 10 Hugh devotes the majority of his entry on astronomy to astrology instead:

It is astronomy, then, which treats the law of the stars and the revolution of the heaven, and which investigates the regions, orbits, courses, risings, and settings of stars, and why each bears the name assigned in it; it is astrology, however, which considers the stars in their bearing upon birth, death, and all other events, and is only partly natural, and for the rest, superstitious; natural as it concerns the temper or "complexion" of physical things, like health, illness, storm, calm, productivity, and

\footnotetext{
${ }^{32}$ Edward Grant, ed., A Sourcebook in Medieval Science (Cambridge, MA: Harvard University Press, 1974), 53.
} 
unproductivity, which vary with the mutual alignments of the astral bodies; but superstitious as it concerns chance happenings or things subject to free choice. ${ }^{33}$

Hugh presents astronomy, a long-accepted element of the quadrivium, by dispensing with it in a few straightforward lines to explain its proper subject matter of the stars and heavens and their regions and movements. Astrology, however, needs, and gets, more. Hugh is very careful to lay out the two sides of astrology: the "natural" and the "superstitious." The natural, he argues, includes the temperament and complexion, attributes of physical bodies that "vary" depending on "the astral bodies." In other words, the fact that the astral realm could influence physical bodies on earth was completely natural and acceptable. On the other hand, what was unacceptable was using the stars to predict this future. This aspect of astrology is "superstitious" because predicting the future contradicts the important Augustinian free will. In terms of Christian theology, the future cannot be set, and predicting the future is untenable either because it cannot be done or because it is absolutely wrong to do so.

It is no surprise that physiognomy does not appear in Hugh's classification scheme since the relevant treatises had not been translated into Latin in the 1120s. However, this entry for astronomy and astrology provides some evidence for how the likes of Hugh of St. Victor might have included it. That the soul and body could influence one another would not have been problematic. In terms of physiognomy predicting the future, the anecdote of Polemon and Hippocrates clears it of just such a

\footnotetext{
${ }^{33}$ Hugh of St. Victor, "The Classification of the Sciences," trans. Jerome Taylor, in $A$ Sourcebook in Medieval Science, 56.
} 
charge. Physiognomy does not, after all, tell the practitioner how the subject must be, but instead, the nature of the subject and to what sorts of behavior the man or woman will naturally lean. Just as an astrologer predicting the future without any uncertainty is "superstitious," so would a physiognomer be who did not allow for his subject to have the possibility of overcoming those natural tendencies through will.

A mere thirty years after Hugh of St. Victor offered his classification of science, Domenicus Gundissalinus (1115-1190) offered his own in De divisione philosophiae (c.1150). Working in Iberia, Domenicus had access to and translated a number of Arabic texts, making his classification representative of the newly emerging ideas of science from Aristotle and Arabic thinkers. Domenicus is thus representative of the new era in his sources, such as al-Fārābi (872-950)'s De scientiis, allowing him to be more elaborate and "mature" in his classification. ${ }^{34}$

In his discussion of astrology, Domenicus draws heavily from al-Fārābi. He writes, "Astrology is the science of mobile magnitude which seeks out with searching reason the courses of the stars, their figures, and the relations (habitudines) of the stars, both with respect to themselves and to the Earth." 35 In other words, astrology deals with the interaction of the world that is "visible and incorruptible" with the corruptible world of men. ${ }^{36}$ This inclusion of al-Fārābi's ideas demonstrates that the influx of treatises from the Islamic world only reinforced the idea that astrology was indeed a science.

\footnotetext{
${ }^{34}$ Grant, A Sourcebook in Medieval Science, 53.

${ }^{35}$ Domenicus Gundissalinus, "The Classification of the Sciences," trans. Marshall Clagett and Edward Grant, in A Sourcebook in Medieval Science, 74.

${ }^{36}$ Gundissalinus, 74.
} 
Again, physiognomy is not mentioned, even though physiognomy was well known in the Islamic world by 1150 . However, again, given the readiness with which Domenicus and al-Fārābi accept astrology's contention that the stars affect those on earth, certainly it would have made sense to classify physiognomy as a science because it emphasizes how the soul influences the body and vice versa, although in this case both are corruptible. ${ }^{37}$

The physiognomy texts would soon be translated and make their way to the university center of Paris and beyond, becoming absorbed in the elite intellectual fabric of western Christendom over the same thirteenth century that saw the synthesis of old and newly translated texts covering every imaginable ancient subject and many new ones.

Hence, physiognomy fits in quite well with medieval classifications of science as long as it does not step into the dangerous ground of fortune telling, an important distinction that holds true as physiognomy texts reached and then circulated in Latin Christendom in the twelfth and thirteenth centuries. But what allowed medieval minds to accept belief in this sort of science? I argue that acceptance of physiognomy represents a partial result of a sort of cognitive dissonance. Theologians such as Albertus contemplated the disquieting knowledge that man is innately sinful while also holding the reassuring certainty that man's purpose is to contemplate God, in part from observing the natural world, the second sacred book written by God. The satisfyingly explanatory power of Aristotle's corpus for that natural world "written" by God, its determining of causes, and its orderly classification were a lovely tool for Albertus and his intellectual colleagues, as they voraciously consumed and engaged with Greek and Arabic texts.

\footnotetext{
${ }^{37}$ The human soul is immortal but not incorruptible. See chapter four of this work for an examination of the link between original sin and a corruptible soul in Christianity.
} 
In order to familiarize the reader with the tenets of physiognomy, Chapter 2 examines and traces the physiognomy texts of the classical and Islamic world, the traces of physiognomy in the early Middle Ages, and the initial reception of physiognomy in the twelfth and thirteenth centuries. In doing so, I lay out the most enduring and influential physiognomy texts and their most important features, both the enduring and less enduring ones, in order to better understand Albertus's role and contributions. Chapter 3 surveys the medical tradition of the classical, Islamic, and Christian worlds as it relates to physiognomy, most significantly, humoral theory and its related ideas, such as the climes. These medical ideas are of special importance because they connect the acknowledged medical science roots with the "occult" or "pseudo-science" of physiognomy. Chapter 4 then examines the most important relevant theories of the soul from the classical through the medieval world in order to better understand the theological foundations upon which medieval physiognomy rested. Chapter 5 encompasses Albertus's own physiognomy within De animalibus, exploring its contributions to medieval science, physiognomy specifically, and briefly outlining the connection between the intellectual milieu of thirteenth-century physiognomy and the widespread popularity of physiognomy in early print culture. 


\section{CHAPTER 2:}

\section{From Omen to Medicalized Scientia: The Evolution of Physiognomy}

\section{Ancient Origins and Greek Physiognomy}

The central tenets of physiognomy are traceable at least as far into history as ancient Mesopotamia. It is possible that physiognomy's roots go as far back as the Akkadian (c. 2350-2170 BCE) and Ur III (2112-2004 BCE) periods, and almost certainly to the Old Babylonian period (c. 1945-1595 BCE), when there was a demonstrable tradition of omen physiognomy, a kind of physiognomy predicated upon the premise that the signs read are from the gods. ${ }^{38}$ A series of 27 tablets known as the Šumma Alamdimm $\hat{u}$ is the best remaining early example of this tradition, containing more than 200 omens. ${ }^{39}$ The tablets themselves are from a later period, perhaps from Ninevah or one of its contemporary scribal centers, but the text on the tablets contains orthographic traces that date it to at least the Old Babylonian period. ${ }^{40}$

Alamdimmî is translated as physiognomic omens, but the origin of the word is "form" or "figure."41 Like most of the later classical and medieval physiognomy traditions, Mesopotamian physiognomic omens were determined by examining a body part. The omens themselves are given as conditional

\footnotetext{
${ }^{38}$ Francesca Rochberg, The Heavenly Writing: Divination, Horoscopy, and Astronomy in Mesopotamian Culture (Cambridge: Cambridge University Press, 2004), 66.

${ }^{39}$ Mladen Popović, "Physiognomic Knowledge in Qumran and Babylonia: Form, Interdisciplinarity, and Secrecy,” Dead Sea Discoveries, 13, no. 2 (2006): 151.

${ }^{40}$ Rochberg, Heavenly Writing, 65. "Old Babylonian-style uncontracted writings and vestiges of the Old Babylonian way of writing certain syllables seen in later omen texts are generally regarded as orthographic indicators of an Old Babylonian origin."

${ }^{41}$ Rochberg, Heavenly Writing, 87.
} 
statements, using if/then. For example, there are a great number of omens based upon the locations of moles. In general, moles, just as other signs in the Alamdimmû, are read negatively when on the right and positively on the left. For instance, "If there is a mole below his right eye: his sons will not have good luck," but "if there is a mole below his left eye: his sons will have good luck and []."42 The Šumma Alamdimmû also includes the signs of behaviors and speech. For example, "If his eyebrow waggles: he will be happy," "If his hands shake: he was given bewitched food to eat," "If he talks to himself: he will acquire barley," and "If his is a grumbler: he will come to ruin.."43

However, what remains to us of the Mesopotamian tradition of physiognomy, while systematic in its lists, reveals a divinatory art, and therefore it is not a discipline or science in the philosophical, theoretical, or medical sense that we see in later centuries. The Mesopotamians attributed the physiognomic (and many other) omens to the authorship of the god Ea. ${ }^{44}$ It would fall to later periods to fully elucidate the methods, theories, and explanations of how physiognomy worked.

The science of physiognomy gained its first full articulations in the classical Greek period and Hellenistic Mediterranean. Two of the earliest works were falsely attributed to Aristotle: a Physiognomy and the Secretum Secretorum, the latter of which alleges to be knowledge passed from Aristotle to his pupil, Alexander the Great (356-323 $\mathrm{BCE})$.

\footnotetext{
${ }^{42}$ Rochberg, Heavenly Writing, 88.

${ }^{43}$ Rochberg, Heavenly Writing, 88.

${ }^{44}$ Rochberg, Heavenly Writing, 87.
} 
The pseudo-Aristotelian Physiognomy, from around 300 BCE, like many of the pre-modern physiognomy texts, has been accessible to modern medievalists since Richard Foerster's Latin edition published in 1893 provided easy access to the text. ${ }^{45}$ This Physiognomy begins with an explanation of and justification for the practice: Again, among things that come about by nature one might especially see the body and soul are connate with each other to the extent that in the case of most affections they are causally active on each other. No animal has ever been born that has the appearance of one animal but the mind of another, but the soul and body are always of the same animal—so that, necessarily, such-and-such a mind follow such and such a body.

Moreover, experts on the animals are always able to judge of character by bodily form: it is thus that a horseman chooses his horse or a huntsman his hounds. If these things are true, and these things are always true, there can be physiognomy. ${ }^{46}$

The author further notes that physiognomy has in the past included three methods: judging a man by the animal he most resembles, drawing parallels between the physiology of races and their "differences and character," and facial expressions or

${ }^{45}$ Richard Foerster, ed., Scriptores physiognomonici; graeci et latini, 2 vols. (Leipzig: B. G. Teubner, 1893). T. Loveday and E.S. Foerster produced a translation that is also a part of the Complete Works of Aristotle edited by Jonathan Barnes. However, Foerester and his contemporaries tended to add corrections that some modern scholars feel to be overstepping. Simon Swain has produced an amended version of their translation in Seeing the Face with ameliorating these corrections in mind.

${ }^{46}$ Pseudo-Aristotle, Physiognomy, translation in Simon Swain and G.R. Boys-Stones, eds. Seeing the Face, Seeing the Soul: Polemon's Physiognomy From Classical Antiquity to Medieval Islam (Oxford University Press, 2007), 639. 
"different conditions of the mind." 47 The last category, that of facial expressions, is described as the least reliable because the fleeting passions of ire, fear, and erotic desire are quickly changeable, and therefore the fewest number of judgments can be made from them. This does not mean that the method is useless because, for example, a facial expression denoting "irascibility and morose sulkiness" could be used to diagnose "an envious disposition." 48

According to the anonymous Pseudo-Aristotle, the animal method is also not without problems. These problems stem from that fact that no man resembles an animal in its entirety. Thus a physiognomic reading based upon this method must include more than one corresponding animal. This method therefore requires the physiognomer to look for braveness, for instance, by examining all brave animals and finding which physical characteristics they share. These are then the characteristics that should be looked for and evaluated in men in order to discover brave ones. ${ }^{49}$

However, even though the anonymous author does not list it as a separate method, the examination of a subject for each possible source of physiognomic signs, e.g. going member by member, Pseudo-Aristotle does list the possible sources for a physiognomer. They are movements and gestures of the body, color, characteristic facial expression, growth of hair, smoothness of the skin, voice, condition of the flesh, parts of the body, and build of the body as a whole. ${ }^{50}$

\footnotetext{
${ }^{47}$ Pseudo-Aristotle, Physiognomy, 639.

${ }^{48}$ Pseudo-Aristotle, Physiognomy, 643.

${ }^{49}$ Pseudo-Aristotle, Physiognomy, 640.

${ }^{50}$ Pseudo-Aristotle, Physiognomy, 641.
} 
The last method that this Pseudo-Aristotle discusses from his original introductory list of three is the differences in character. The third chapter is organized by these character types. In order, they are those who are courageous, cowardly, talented, insensible, shameless, orderly, cheerful, sad, deviant, bitter, fierce-tempered, mild, dissemblers, petty-minded, fond of gambling, fond of abuse, merciful, hearty eaters, lascivious, somnolent, loquacious, and owners of a good memory. ${ }^{51}$

However, a fourth important, but unnumbered, method of physiognomy follows the three listed methods from the introduction. This anonymous author does not officially name it, but he nevertheless addresses the importance of different readings based upon masculine and feminine characteristics. In general, he writes in the second chapter, "males are bigger and stronger than females of the same kind, and their extremities are stronger and sleeker and firmer and capable of more perfect performance of all functions." 52 Furthermore, the fifth chapter contains a great deal of information on masculine and feminine characteristics mixed with material on animal characteristics. The female is more mischievous and reckless. Physically she has a smaller head, narrower face, thinner neck, weaker chest, smaller flanks, "less stout" hips, and more delicate feet. The anonymous author sums up the female physical traits, saying, "In short, the build of her body is more pleasing to the eye and softer rather than imposing, and she is in comparison feeble and tender, and of moister tissue. The male is the opposite of all this: his is the braver, more upright nature, whilst the female is more timid and less

\footnotetext{
${ }^{51}$ Pseudo-Aristotle, Physiognomy, 645-47.

${ }^{52}$ Pseudo-Aristotle, Physiognomy, 643.
} 
upright." ${ }^{53}$ The perfect examples of the masculine and feminine in animal form are, for the author, the lion and the leopard. The lion is the perfect form of a male while "of all the animals accounted to be brave, the leopard approximates more closely to feminine type, save in its legs."

The sixth chapter deals with general signs. Arranged in what would become the most common physiognomic order, it starts with the head, with emphasis on the eyes, and moves to the feet. However, it first begins with male and female signs before starting on the members of the body. It also contains some differences based on races, specifically naming "Egyptians and Ethiopians," who are given as examples for his statement that "too black a hue marks the coward.",55

Overall, then, this classical Greek physiognomy text attempts to provide a practical list of physiognomic signs. This, as we have seen from the much older Mesopotamian omen tradition, is not new. However, the anonymous author also provides an explanation for how physiognomy works and an analysis of the discipline's different methods and their levels of utility. In many ways, then, the Greek addition to physiognomy was to remove it from its previous direct connection to religiously-based divination and to add a theoretical discussion to the practical lists that could be referenced by a practicing physiognomer.

\footnotetext{
${ }^{53}$ Pseudo-Aristotle, Physiognomy, 651.

${ }^{54}$ Pseudo-Aristotle, Physiognomy, 651.

${ }^{55}$ Pseudo-Aristotle, Physiognomy, 657.
} 
The second source of physiognomy falsely attributed to Aristotle is the Secretum Secretorum, or the Kitāb Sirr al-asrār in Arabic. Physiognomy is only one of the subjects of this text, but it became an important source in both the Islamic and Christian worlds, with more than 500 manuscripts from the twelfth century on. ${ }^{56}$ In part this is due to its longer sections of advice for princes, including the proper behavior of kings, how to maintain health, the seasons and the best actions to take in each, natural heat, the qualities of meats, and justice. These contents explain its alternative title, the Book of the science of government: on the good ordering of statecraft. In this sense, princes could use the chapter on physiognomy as a tool for evaluating their courtiers and advisors.

The physiognomy section begins with a brief outline of the perfect companion for kings:

The best proportioned construction is of him who possesses medium stature, black hair and eyes — the latter somewhat deep set—round face, white mixed with red or moderately brown colour, with perfect form and well-proportioned body, head neither too large nor too small. Who speaks little except on necessary occasions, a voice neither too loud nor too low, inclining towards thinness but not too thin. And whose temperament inclines towards spleen and bile. Such a man is of a perfect formation. Choose him for thy company. ${ }^{57}$

\footnotetext{
${ }^{56}$ M.A. Manzalaoui, ed., Secretum Secretorum: Nine English Versions, vol I. (Early English Text Society/Oxford University Press, 1977), ix. There are, however, no surviving Greek versions of the text.

${ }^{57}$ Robert Steele, ed., Secretum Secretorum cum glossis et notulis (London: Oxford University Press, 1920), 220.
} 
In this, the Secretum Secretorum is an early example of one of the guiding rules of most physiognomy from the Greeks on: that while few signs correspond to "good" readings, those that do are generally ones of moderation.

The rest of the physiognomy section consists of the expected lists of physiognomic readings arranged in the familiar order of the body parts from head to toe. For instance, the first few signs have examples, such as "The man whose eyes are large and protruding is envious, shameless, and lazy, and is unworthy of being trusted, especially if his eyes are blue" and "A wide forehead without any wrinkles in it, indicates quarrelsomeness, mischievousness, carelessness, and vaingloriousness." ${ }^{, 58}$ The final characteristics include that "broad and fleshy feet indicate ignorance and love of oppression, and small and soft feet indicate wickedness." ${ }^{, 59}$ Also included are a few signs for things like gait and voice, such as "He whose steps are short and quick is hasty in his actions, ill-natured, unmethodical in his affairs, and of evil design.",60

The entire physiognomy section occupies only five or so pages in most modern editions but still ends with an admonition not to rely upon any single sign: "But you must not, O Alexander, form your judgment of a man's character by one sign only, but judge them on the whole. And when you find contrary signs lean towards those that are stronger

\footnotetext{
${ }^{58}$ Pseudo-Aristotle, Secretum Secretorum, 220-221.

${ }^{59}$ Pseudo-Aristotle, Secretum Secretorum, 223.

${ }^{60}$ Pseudo-Aristotle, Secretum Secretorum, 223.
} 
and more conclusive so that you may be rightly guided and achieve your objects." ${ }^{61}$ This admonition is both practical and theoretical. Such an admonition would allow for a more accurate practice of the discipline, yet, at the same time, it also mirrors some of the theory introduced by the pseudo-Aristotelian Physiognomy.

Despite the power of the texts falsely attributed to Aristotle, it was Polemon of Laodicea (88-144 CE) who was arguably the most influential of the Greek physiognomers. Polemon's work contains a trio of the most important ways of interpreting and grouping physiognomic signs: whether signs are masculine or feminine, which animal(s) the subject best resembles, and an analysis made body part by body part, with the eyes trumping all other signs. Also in Polemon is an additional common thread in physiognomy, associating a physiognomic reading based upon the geographic origin of the subject. However, it is the first three that he emphasizes in his main arguments for and descriptions of the science. For Polemon, in order to get the best physiognomic reading, these three considerations are not evaluated individually, but together. He writes,

So when you look at a man, compare him and think about him: do you see that he is masculine or feminine? In addition to that, a similarity to which animal do you see dominant in him? Combine these signs with the signs of the eye and then judge according to what you see of this ... Furthermore, if I mention to you the similarity in man to animals, then what do you know of that from elsewhere and what is in the nature of each animal with a

${ }^{61}$ Pseudo-Aristotle, Secretum Secretorum, 224. The translation has been slightly modernized. 
similarity to man dominant in it will help you along ... For you will not find anyone who does not have a similarity to an animal, and a nature like its nature. ${ }^{62}$

Polemon's Physiognomy is divided into seventy chapters. The first thirty are organized by body part, with most chapters offering animal counterparts to various types of features. There are also four chapters, 49-52, devoted to signs that are not descriptive of single body members, such as the gait and voice of a person. The third group of chapters, 53-68 and 70, are organized around kinds of men based upon their natural characters, in a similar fashion to that of the pseudo-Aristotelian Physiognomia. Polemon's categories include those men who are bold and strong, cowardly, love knowledge and philosophy, have little modesty, love decoration and affectation, are intelligent and shrewd, are very sad and depressed, are effeminate and womanly, are humble, mock people, love to amass money, are stupid, have hypocritical souls, "whom evil and trouble [approach] without [their] knowledge," and "who [think] about great trials before any of them happen." The majority of these chapters are quite short. An extreme example of this brevity is the text of the entirety of Chapter 63: "The sign of the man who mocks is that he is found with sharp sight and a muffled voice, thin around the edges of his eyes, and when he walks all his limbs move." ${ }^{\prime 64}$

Chapter 69 is related to this third group of types of men, but is the only one at least titularly dedicated to a type of woman: "the sign of the woman's passion for

\footnotetext{
${ }^{62}$ Polemon, Physiognomy, in Seeing the Face, 381.

${ }^{63}$ Polemon, Physiognomy, 339-40.

${ }^{64}$ Polemon, Physiognomy, 453.
} 
unknown men." ${ }^{, 65}$ This chapter is not brief in comparison to the others in this group. Instead, it is a somewhat lengthy story of a bride who conspired to marry someone other than her official intended. Polemon relates that "I looked at the bride, and she laughed without laughter, the action of a sad person, who feigns joy but is not joyful. ... [Men] overpowered the bride and made off with her. Afterwards I heard the people saying that it had been with her approval. ${ }^{, 66}$ However, most of the chapter is actually about the signs Polemon read in one of the groom's companions, specifically the one who ultimately stole the bride.

One last important trend to note in some of the later chapters on types of men is that Polemon is in some ways presenting case studies. These are based upon his travels and include descriptions of the men that he "read" and then proof of how the readings were successful. It is in a place he calls "Calydna" that Polemon found his example of a man who dwells on future troubles before they arrive. ${ }^{67}$ The bride's story takes place in "Dmsws." ${ }^{68}$ Other travel includes "the land of Pamphylia, in a city called Perge." case studies and travel stories are worth noting because most later works of physiognomy and many manuscripts of Polemon's work leave them out. This is likely because they

${ }^{65}$ Polemon, Physiognomy, 457.

${ }^{66}$ Polemon, Physiognomy, 458-459.

${ }^{67}$ Polemon, Physiognomy, 461.

${ }^{68}$ Polemon, Physiognomy, 457. Some scholars have argued for Samos as the proper reading.

${ }^{69}$ Polemon, Physiognomy, 457. 
verge on predicting the future, for example that Polemon claimed he knew the woman's wedding would not go as planned because of his physiognomic readings.

Because these places are mentioned as backdrops for Polemon's experiences, they are not part of a physiognomic category or reading per se. However, there are a number of mentions of racial characteristics, in the sense of those physical characteristics and the related traits being associated with those from a certain geographical region. For instance, in a chapter on the signs of the hair, Polemon mentions, "As for red hair that turns towards whiteness, you find this among Slavs and Turks. It indicates lack of understanding and knowledge and an evil way of life, so be very sure about this." ${ }^{, 70}$ In a chapter on the color of the body, he says, "The colour black is an indication of cowardice, long-lasting ambition, and dejection. Such are the people of the south, the Ethiopians and the Zanj, the people of Egypt, and what is near them."71 Those from South Asia get a more positive reading. Polemon writes, "The people of the land of India are not very different from the people of the south because of their closeness to the sea and because of the similarity of the produce of their land to that of the people of the north. For this reason their bodies and faces are beautiful, and their figure is evenly proportioned." ${ }^{, 2}$ On the other hand, the ideal is the "pure Greek" from a place like "Argos" or “Corinth.” Polemon describes this ideal in detail:

The pure Greek is of medium stature, between tall and short, broad and weak. He is of erect posture, beautiful in face and appearance, white in

\footnotetext{
${ }^{70}$ Polemon, Physiognomy, 431, 433.

${ }^{71}$ Polemon, Physiognomy, 427.

72 Polemon, Physiognomy, 425.
} 
colour, mixed with red, medium in flesh, with medium palms and elbows, alert, quick to learn, neither small nor large of head, in his neck thickness and strength. His hair is soft and red, with some curliness and some waviness on account of its lankness. In his face there is squareness, in his lip slimness, and his nose is pointed and evenly proportioned. His eyes are moist, bluish-black, very mobile, and very luminous. This is the description of the pure Greek.

This example is in the minority of positive readings. However, among positive physiognomic readings there follow two major trends: describing the author's own people as the best and describing the best as denoted by moderation. Notice, for instance, the number of times that Polemon describes the Greek ideal as "medium" or having aspects "between" two extremes in the above passage.

Polemon and the works attributed to Aristotle quickly became the authorities on physiognomy in Greek. This does not, however, mean that work on or interest in physiognomy in Greek ended with Polemon. One influential example is Adamantius (fl. third century CE), who was a physician in Alexandria. ${ }^{73}$ Adamanitius's physiognomic work is primarily a summary of the previous Greek works. It contains an abridgement of Polemon, though it begins by citing Aristotle and others as sources. It is also an early instance of an author omitting many of Polemon's examples and stories at the end of his work, and, in addition, it abbreviates many of the more theoretical sections such as why the eyes are most important and theories on animal signs and the importance of masculine

\footnotetext{
${ }^{73}$ Ian Repath argues for the likelihood of this being the same Adamantius who wrote $O n$ winds. See page 487.
} 
and feminine signs. Though Adamantius himself claims that his work is a paraphrase to which he has added his own thoughts, scholars have noted that what is there is not much if any original thought and that he follows the order of Polemon's work extremely closely. ${ }^{74}$ Nevertheless, Adamantius was often added to the list of important physiognomic authors by later generations because of his epitome.

\section{Islamic Physiognomy}

Pre-Islamic Arabia had its own history of divination. A twentieth-century scholar saw the Islamic world as the blind inheritor of Mesopotamian civilization, including its traditions of divination. ${ }^{75}$ While these were certainly present, there were also Persian influences, including greater emphasis on astrology. ${ }^{76}$ The Persians listed physiognomy as a type of interpretation of omens or divination based on reading signs. The latter was known as firāsa, the word later often used in Arabic for physiognomy. Along with the signs of human and animal body members (firāsa), are signs of the veins, shoulder blades, dice, footprints, rhapsodomancy (divination based upon lines of poetry), and the drawing of lots. ${ }^{77}$ However, what makes divination specifically "Semitic," according to early scholars, is not its physiognomy or firāsa, but its blending of Mesopotamian omens with Persian astrology and an emphasis on oneiromancy (the interpretation of dreams to

\footnotetext{
${ }^{74}$ Repath, 488.

${ }^{75}$ Toufic Fahd, La Divination Arabe: Études Religieuses, Sociologiques et Folkloriques sur le Milieu Natif de L'Islam (Leiden: Brill, 1966), 1-2.

${ }^{76}$ Fahd, La Divination Arabe, 25-31.

${ }^{77}$ Fahd, La Divination Arabe, 31-32.
} 
foretell the future), including ornithomancy (divination from the actions of birds), and cleromancy (casting lots or shooting arrows through texts or poems). ${ }^{78}$

A comprehensive Muslim source on divination in pre-Islamic Arabia and its evolution in the early years of Islam comes from the seventeenth-century Ottoman historian Mustafa bin Abdullah (1609-1657), known by the pen name Kâtip Çelebi (Gentleman Scribe) or Haji Khalifa. His Kashf al-zunūn 'an asāmī al-kutub wa-al-funūn, (The Removal of Doubt from the Names of Books and the Arts), an alphabetical Arabic bibliographical encyclopedia, divides divination into three main categories. These are physiognomy/firāsa, magic, and astrology. ${ }^{79}$ In his list of subjects covered under physiognomy or firāsa, Haji Khalifa lists birthmarks and moles, chiromancy (palm reading), omoplatoscopy (shoulder blade readings), footprint readings, divination from morphoscopic traits, detection of sources or minerals, knowledge from signs of rainfall, knowledge of the future from past events, and palomancy (divination through involuntary bodily movements). Roughly half of these would fit under the umbrella of the Greek idea of proper physiognomic signs: moles, palms, shoulder blades, and genetic and morphoscopic traits are all from body parts in some way while footprints and palomancy are compatible with physiognomic ideas of reading gaits and body movements as signs. In general the divinatory arts listed under magic and astrology do not match Greek ideas of physiognomy, although under magic we do find the art of recognizing frauds, a subject that seems to correspond with the mirror for princes style of the Pseudo-Aristotelian Secretum secretorum.

\footnotetext{
${ }^{78}$ Fahd, La Divination Arabe, 23.

${ }^{79}$ Fahd, La Divination Arabe, 39-41.
} 
These divinatory arts seem at first glance to be at odds with Islam. Nevertheless, those forms that are more similar to physiognomy persisted into the seventh century and far beyond. In terms of the early years of Islam, one of the most important forms of divination's direct relationship to physiognomy was the practice of readings based upon genealogical factors (qiyāfa). This practice involved examining moles, body parts, etc. and was apparently used by the Quraysh tribe, the prophet Muhammad's tribe that controlled Mecca, to examine their newborn boys. While the story may be apocryphal, the Prophet himself was said to have been examined as a baby, with the examiner exclaiming, "Woe to you! Bring back to me the child I have just seen! By God, he will have an important role to play!" 80 If qiyāfa could be understood as a method used to read Muhammad's destiny, it is quite easy to see how the later introduction of Greek physiognomy could quickly find favor, although it could be equally problematic because of its predictive rather than tendency-revealing nature.

Despite the long Middle Eastern tradition of divination, the theoretical and systematic organization of Islamic physiognomy did not truly begin until the translation movement from Greek, Syriac, and other languages into Arabic began under the Umayyad Caliphate. Nevertheless, prior to the translation movement the Qur'ān, hadith, and other Islamic texts built upon the previous divination-based physiognomy.

The clearest example is found in the eschatological verse that says of the end of the world that "On that day when faces will be white or black" (3:106) we will know the

\footnotetext{
${ }^{80}$ Fahd, 371. Fahd's French translation of the Arabic is "Malheur a vous! Faites revenir a moi cet enfant que je viens de voir! par Dieu, il aura un rôle important a jouer!"
} 
virtuous by their white faces and the sinners by their black faces. ${ }^{81}$ Christian Lange has pointed out that the word face is mentioned 72 times in the Qur'ān, including eleven times to refer to the face of God. ${ }^{82}$ In both the references to God and to men, the Qur'ān uses the face as a synecdoche. This makes what happens to the faces of sinners at the end of times a demonstration of their characters. The Qur'ān tells us that the "guardians of Hell" will "beat the sinner's faces," cut off their ears, gouge out their eyes, trample their tongues, and smite them in the face with prayer rugs. A sinner's upper lip will be "rolled up until it reaches the middle of his head, and his lower lip hangs down until it beats upon his navel." 83

In interpreting these verses, there was a consensus among Sunni Muslim religious scholars that at the apocalypse sinners' faces would be literally black. ${ }^{84}$ Their sins were thought to include unbelief, apostasy, innovation, "people of sectarian or heretical inclinations ( $a h l a l-a h w \bar{a}$ ')," hypocrisy, Shi'ite or other sectarian belief, tyrannical rule, and making public grave sins (al-mu'linūna bi-l-kabā'ir). ${ }^{, 85}$ While some argued for a more metaphorical reading of face color in life, many of the most influential scholars applied the literal interpretation to the living as well. Al-Ghazālī (d. 505/1111) tells a

\footnotetext{
${ }^{81}$ Christian Lange, “'On That Day When Faces Will Be White or Black' (Q3:106): Towards a Semiology of the Face in the Arabo-Islamic Tradition, "Journal of the American Oriental Society, vol. 127, no 4 (Oct/Dec, 2007): 429. The Arabic reads yawma tabyaddu wujūhun wa-taswaddu wu jūhun.

${ }^{82}$ Lange, “On That Day When Faces Will Be White or Black,"431.

${ }^{83}$ Qur'ān verses, 8:50, 47:27, and 17:97 pointed out by Lange, "On That Day When Faces Will Be White or Black," 432.

${ }^{84}$ Lange, "On That Day When Faces Will Be White or Black," 429.

${ }^{85}$ Arabic from Lange, “On That Day When Faces Will Be White or Black,” 430.
} 
story of a pilgrim in his Ihyā' 'ulūm al-din: "When I set out for Mecca for the first time in the company of my father, I went to sleep at a way-station. While I was asleep someone called to me and said, 'Arise, for God has caused your father to die and has blackened his face.' Terrified, I arose, and removed the garment from his face, and behold, he was indeed dead, and his face had turned black." ${ }^{86}$ Blackness of the face, then, was a visual indicator of $\sin$.

This belief in the literal connection between the state of the soul and the color of a man's face provided a distinctly Islamic avenue for not just allowing physiognomy, but encouraging it. Hanbalī jurist Ibn Qudāma (d. 620/1223) wrote that "in it [the face] are wrinkles, lines, hairs, intrusions, and protrusions." ${ }^{87}$ Lange points out that the Arabic words for these facial features have alternate meanings: wrinkles (ghudūn) can mean hardships, facial lines (as $\bar{a} s \bar{\imath} r$ ) can mean expressions, hairs (shu' $\bar{u} r$ ) can mean feelings, intrusions (dawākhila) can be used for inner thoughts, and protrusions (khawārija) can mean outer expressions. ${ }^{88}$ This resulting native tradition of physiognomic divination is key to understanding how the Greek scientia quickly found a receptive foundation in the Islamic world.

The translation movement from Greek into Arabic began soon after the military expansion of the Islamic Caliphate under the four rashidun (rightly guided Caliphs). The

\footnotetext{
${ }^{86}$ From Lange, "On That Day When Faces Will Be White or Black," 430. Lange points out that the man's face is later returned to white by a miracle from the Prophet. His interpretation is that the story illustrates the anxiety over whether belief ( $\bar{\imath} m \bar{a} n)$ will provide salvation and the possible punishment for sins.

${ }^{87}$ Lange, "On That Day When Faces Will Be White or Black,"434.

${ }^{88}$ Lange, "On That Day When Faces Will Be White or Black,"434.
} 
conquest of what had been Roman Palestine and Syria provided access to Greek texts. However, it was under the Umayyad dynasty (661-750), which ruled from Damascus, that the translation of Greek texts into Arabic began in earnest. This translation movement continued under the Abbasids (750-1258) in their newly constructed capital, Baghdad.

The earliest translations were largely the work of Syriac-speaking Nestorian Christians who spoke both Greek and Arabic. In Baghdad, the movement continued among translators who often received generous patronage from the Caliph himself or his highest viziers. ${ }^{89}$ This resulted in a spate of translations that was dominated by Greek science but also included many works of philosophy and other disciplines.

After the translation provided access to the Greek tradition of physiognomy, one of the earliest influential Islamic thinkers to take advantage of these new translations was Abū Bakr Muhammad ibn Zakarīyā' al-Rāzī (d. 925). Known to European as Rhazes, he was a Persian polymath, but best known as a physician. ${ }^{90}$ His short but influential medical textbook, the Liber ad Almansorem (Bookfor Al-Mansur), integrated

\footnotetext{
${ }^{89}$ For a thorough discussion of the Greek to Arabic translation movement, see Dimitri Gutas, Greek thought, Arabic culture: the Graeco-Arabic translation movement in Baghdad and early 'Abbasid society ( $8^{\text {th }}-10^{\text {th }}$ centuries) (London: Routledge, 1998).

${ }^{90}$ In order to distinguish Abū Bakr Muhammad ibn Zakarīyā' al-Rāzī (d. 925) from the later Fakhr al-Din al-Razi (d. 1209), the former will be referred to hereafter as Rhazes and the latter as al-Razi. Also note that al-Razi is sometimes transliterated in other sources as ar-Razi because it is pronounced that way in spoken Arabic although the letter itself is roughly equivalent of the English L.
} 
physiognomy into Galenic medicine, which was another fruit of the Syrian and Baghdadi translation movement. ${ }^{91}$

The Liber ad Almansorem is divided into ten tracts that cover subjects such as the anatomy of the bodily members, medicines, sanitation, movement, surgery, wounds, and curing poisons. However, the second tract, which is largely dedicated to Galenic ideas of the complexion of the body and humors, also includes physiognomy. After a section on the humoral signs of the organs, such as the heart, lungs, and testicles, Rhazes turns to physiognomy.

There is no beginning theoretical discussion of physiognomy or argument for its utility. Instead, the discussions of humoral signs abruptly segue into physiognomic signs, with chapters 26 and 28 through 46, roughly the middle third of the tract, organized into lists of the familiar groupings by body part. In an approach divergent from the Greek tradition, instead of starting with the eyes, Rhazes starts his signs with those of the hair. Straight hair is a sign of timidity, curly hair one of bravery, lots of belly hair one of a love of luxury, and so on. ${ }^{92}$ Chapter 27 is also on signs, but instead of physiognomic signs of color, Rhazes discusses color as a sign of humoral complexion. Only then does the Liber ad Almansorem move onto the queen of all physiognomic body parts that is in most other works addressed first: the eyes. Here the signs largely match the Greek tradition with a long chapter devoted to signs such as large eyes, which are signs of a reluctant person. However, Rhazes cannot refrain from mixing some humoral information directly into his

\footnotetext{
${ }^{91}$ In Arabic the title is Kitāb al-Manșūrī fĩ al-țibb, or in English, The Book on Medicine for Mansur.

${ }^{92}$ Rhazes, Liber ad Almansorem (1496), 8.
} 
physiognomic signs. For instance, he tells us that "those whose eyes protrude are revealed to be hot and deceivers." ${ }^{93}$ After the eyes, Rhazes continues in the common physiognomic practice of ordering his signs roughly from head to toe, with laughter and movement signs sandwiched between muscles and the neck.

The penultimate set of chapters, $47-55$, is devoted to physiognomic signs of different personality tendencies and different kinds of men. The personality tendencies include bravery, timidity, intelligence, and good nature. The kinds of men discussed include the philosophical man, the man without shame, the man of evil habits, and the man given to luxury. Of these, the philosophical man is most interesting because his is the only positive portrait of the group. A philosopher can be recognized because he stands erect, has moderate amounts of flesh and muscle, has a complexion that is a mixture of red and white, and hair "between much and little." ${ }^{94}$ In short, he is a picture of moderation.

The final three chapters are devoted to the subjects that do not fit neatly anywhere else. Chapter 56 covers the feminine signs and is followed by chapter 57 , which covers the signs of a eunuch. Chapter 58 includes the only guide to the practice of physiognomy in the Liber ad Almansorem. Here, Rhazes warns his readers that it is necessary that if you want to judge, you pay attention to [your] purpose. Although these [physiognomic] signs point to contraries, they are full of virtue and testimony. And so pay attention to the stronger ones,

${ }^{93}$ Rhazes, Liber ad Almansorem (1496), 8.

${ }^{94}$ Rhazes, Liber ad Almansorem (1496), 8v. Note: the 1496 edition's pages are marked with only an Arabic numeral and only on the recto side. I am adding the verso designation to differentiate it from the other side. 
and judge their testimony, which is often similar. Moreover, skill

necessitates restraint: as long as the sign is from the eyes, assess all the

other signs as less strong and firm. ${ }^{95}$

These admonitions closely follow those of Polemon and his contemporaries, testifying to Rhazes's familiarity with the Greek works of physiognomy.

While largely devoid of theory, Rhazes's Liber ad Almansorem sets the tone for Islamic physiognomy. In terms of sources, it is largely dependent upon the works of Greek physiognomy in general and Polemon specifically. Rhazes's work, however is more dependent upon Galen than it is Polemon, a characteristic seen in the way that his physiognomy abuts his discussion of the humors with no real preface or introduction to differentiate physiognomy from medicine. The Greeks had largely removed the religious aspects from physiognomic divination, applying logic to the practice in such a way that it became a Greek science. However, Rhazes and other early Arabic authors medicalized it. By tying it so firmly to Galen and the best of classical medicine, these thinkers allowed physiognomy to endure in the Islamic world and in much of Christendom for the next millennium. ${ }^{96}$

${ }^{95}$ Rhazes, Liber ad Almansorem (1496), 9. Oportet ut cum iudicare volueris: non unam tam attendas intentionerum. Etsi quae significationum acciderit contrarietas: ipsarum virtutes et testimonia mettaris. Deinde ad fortiores ipsarum declina: et earum iudica testumonio: et similiter que plures sunt. Preterea scire debes: quam factet significatio et percipue oculorum: omnibus aliis significationibus in fortitudine et firmitudine preiudicat.

${ }^{96}$ While the medicalization of physiognomy in the Islamic world is the most accepted scholarly viewpoint, Joseph Ziegler has argued that it was only truly medicalized by Christian Europeans with the aid of Scholasticism in the thirteenth and fourteenth centuries. Joseph Ziegler, "Philosophy and Physicians on the Scientific Validity of Latin Physiognomy, 1200-1500," Early Science and Medicine 12 (2007): 285-312, especially 291. 
Perhaps the best example of the endurance of medicalized physiognomy is the work of Fakhr al-Dīn al-Rāzī (d. 1209), three centuries after Rhazes. In al-Razi’s work the medicalized physiognomy of Rhazes blends together with the physiognomic mentions and classifications of other physicians, such as Avicenna (or Ibn Sīnā, c. 980-1037). AlRazi mixes together this Islamic form of physiognomy with Polemon, the Sirr al-asrār, which takes shape in the Kitāb al-firāsa (Book of Physiognomy), which, as the title implies, is a work entirely devoted to physiognomy. It is worth examining because alRazi was no mere epitomizer, nor solely a synthesizer, but instead enriched the medicalized physiognomic tradition and physiognomy in general by making additions and providing commentary. ${ }^{97}$

His Kitāb al-firāsa is divided into three discourses. In the first chapter of the first discourse al-Razi lays out his definition and explanation of physiognomy:

Physiognomy consists of judging internal character from the exterior appearance. In order to explain this definition, we will say that the temperament is either the soul or the instrument of the soul in the performance of its acts; in each of these two cases, the exterior appearance and the internal character must necessarily depend on temperament. If this is proven, it follows that to infer the internal character from the exterior appearance is the same as inferring the existence of one of the two facts

${ }^{97}$ Hoyland, "Islamic Background," 262. 
concurrent to the existence of the other; and there is no doubt that a parallel consideration is true..$^{98}$

Al-Razi also later adds an endorsement for the usefulness of the practice, noting that "if this art can let us know the character of people, the good as well as the bad, the advantage you get will be enormous." ${ }^{99}$ The second chapter adds a defense for physiognomy against naysayers, noting that "the principles of this science rely on natural science, and its developments are based on experience. It is on the same footing as medicine, from which it follows that all criticism directed against physiognomy is thereby, against medicine." ${ }^{100}$ Together these passages in al-Razi's theoretical discourse on physiognomy offer strong evidence for two of the themes other than medicalization that had developed in Islamic physiognomy by this time: a justification based upon the connection between soul and body and the usefulness of the practice. Together these placed physiognomy firmly in the realm of science.

${ }^{98}$ Translated from the French edition: Youssef Mourad, La Physiognomie Arabe et le Kitāb al-Firāsa de Fakhr al-Dīn al-Rāzi (Paris: Librarie Orientaliste Paul Geuthner, 1939), 77. La Physiognomy consiste à juger du caractère interne d'après l'aspect extérieur. Pour expliquer cette définition, nous dirons que le tempérament est ou bien l'âme ou bien l'instument de l'âme dans l'accomplissement de ses actes; dans chacun de ces deux cas, l'aspect extérieur et le caractère interne doivent dépendre nécessairement du tempérament. Si cela est prouvé, il s'ensuit qu'inférer le caractère interne de l'aspect extérieur est du même ordre que d'inférer l'existence d'un des deux faits concomitants de l'existence de l'autre; et il ne fait aucun doute qu'une pareille considération est vraie.

${ }^{99}$ Mourad, La Physiognomie Arabe, 78. Si cet art peut nous faire connaître le caractère des gens, en bien comme en mal, l'avantage qu'on en retirera sera énorme.

${ }^{100}$ Mourad, La Physiognomie Arabe, 78. Les principes de cette science s'appuient sur la science naturelle et ses développements sont basés sur l'expérience. Elle est sur le même pied que la médecine, d'où il s'ensuit que toute critique dirigée contre la physiognomonie l'est par le fait même contre la médecine. 
The thoroughness of the medicalization of Islamic physiognomy is further attested to by the second discourse, which focuses on, and is divided by, the temperaments. AlRazi begins with hot, and then proceeds to cold, humid, dry, hot/dry, and hot/humid. For each temperament, he links activities (i.e. level of movement and thinking/intelligence), explores the qualities of the subject's faculties (procreative, growth, nutritive, expulsive), and enumerates the reactions (i.e. temperature of skin, reactions to medicine). ${ }^{101}$ The cold/dry and cold/humid temperaments are simply given as the opposite of hot/humid and hot/dry respectively. There are also chapters on the temperaments of the mental faculties and the complexions of the brain, eyes, language, voice, and heart. Of these, the eyes and voice are the most universally acknowledged as physiognomic signs.

In addition, there are sections in the second discourse divided by age (adolescence, youth, maturity, and old age), with each stage given a general character portrait. For instance, adolescents have extremely changeable and unstable humors and their "concupiscible appetites are limited to the needs of the natural body," with needs such as love, table, and ornament predominant. ${ }^{102}$ They are also said to be full of pity and "modesty, for they have not yet committed any indecent act." ${ }^{\prime 103}$ Next, there are sections divided by the station of birth (nobles and the rich) and geography (hot and cold environments).

However, it is in the third and final discourse that al-Razi moves into the expected and typical listing of physiognomic readings by body part, or member. Al-Razi, like so

\footnotetext{
${ }^{101}$ Mourad, La Physiognomie Arabe , 95-99.

${ }^{102}$ Mourad, La Physiognomie Arabe, 107.

${ }^{103}$ Mourad, La Physiognomie Arabe, 108.
} 
many of his fellow physiognomers, first advises the reader in a brief preface that the signs of the face are more important than those of any other members. Yet, he also includes a brief discussion of the face's connection with the mental faculties, noting that "what makes mankind human is understanding, reason, reminiscence and memory. All these activities have for a seat the brain, because the head is the sanctuary of thought." ${ }^{104} \mathrm{He}$ then continues on to make the connection between these faculties and physiognomy. "That," he says, "is why the head is the part of the body in which the psychic influences are expressed with the most perfection. Thus, it is the head with its various aspects that possesses the most significant significance with regard to the manifestations of the soul."105 Thus, he provides a type of justification by means of proximity for giving the most weight to the signs of the face and head.

Al-Razi then returns to the more expected listing of signs divided by body part in the following order: forehead, eyebrows, the eye, the nose, the mouth/lips/tongue, the face as a whole, the laugh, the ears, the neck, the voice/respiration/speech, the flesh, the thorax, the belly, the back, the arms/hands, and finally the size of the hip/leg/foot. AlRazi utilized this clearly established head-to-toe approach, with the common mixes of visual and auditory signs, while matching Rhazes's decision to begin with the top of the head/hair instead of the eyes.

${ }^{104}$ Mourad, La Physiognomie Arabe, 115. Ce qui fait l'humanité de homme c'est la compréhension, la raison, la réminiscence et la mémoire. Toutes ces activités ont pour siège le cerveau, car la tête est le sanctuaire et de la pensée.

${ }^{105}$ Mourad, La Physiognomie Arabe, 115. C'est pourquoi la tête est la partie du corps où les influences psychiques s'expriment avec le plus de perfection. Ainsi, c'est la tête avec ses divers aspects qui possède la plus grande portée significative en ce qui concerne les manifestations d l'âme. 
Rhazes and al-Razi together demonstrate the most important trends of Islamic physiognomy: its medicalization as it was synthesized and joined to Greek medical theory. Almost without doubt, this medicalization allowed physiognomy to be even more strictly defined as a science in the medieval Islamic world than even the Greeks had done in theirs. In part this leaning may explain the loss of some of Polemon's stories. The Islamic world showed itself to be quite comfortable absorbing Greek science early in the translation movement, and while the divinatory and religious aspects of its own tradition made medicalized physiognomy understandable, they had no place in a Greek science, or more specifically a natural science.

Avicenna's classification of physiognomy as a science likely had a great deal to do with its acceptance in both the Islamic and later medieval Christian worlds. Both his Kitāb al-najāt (The Salvation) and his Kitāb al-shifā' (The Cure) contain sections on Aristotle's Prior Analytics where he includes analysis of the use of physiognomic syllogism to compare the resemblances of men. ${ }^{106}$ This is based upon Aristotle's note in Prior Analytics (70b) that "physical marks" allow assessment of the psyche or character. ${ }^{107}$ Yet Islamic thinkers did contemplate the relationship between natural science and religion in physiongomy, exploring the connections between the two. These

\footnotetext{
${ }^{106}$ Anna Askoy, "Arabic Physiognomy as a Link Between Astrology and Medicine," In Astro-medicine: astrology and medicine, East and West, Anna Askoy, Charles Burnett and Ronit Yoeli-Tlalim eds. Micrologus' Library, 25 (Florence: Sismel-Edizioni del Galluzzo, 2008), 127. Also, Thomann, "Avicenna über die physiognomische Methode," in Rüdiger Campe and Manfred Schneider eds., Geschichten der Physiognomik: Text, Bild (Freiburg: Rombach Verlag, 1996), 47-63, 52.

107 Askoy, “Arabic Physiognomy as a Link,” 120.
} 
connections lay in the idea that both physiognomy and divination involve using the zâhir ("visible exterior") to say something about bātin ("hidden reality"). ${ }^{108}$

Sometimes referred to as Sufi, Andalucian mystic Ibn 'Arabī (1165-1240)

embodies this embracing of the connections between the physiognomy of natural science and religion. He also bucks the trend of finding physiognomy attached to medical works or in medicalized stand-alone volumes. Instead, in chapter 148 of his Futūbāt (Book of Meccan Revelations) Ibn 'Arabī addresses physiognomy from within a religious work. ${ }^{109}$ Perhaps because of this placement, the chapter begins with an unusually long Islamic theoretical discussion of physiognomy that takes up the majority of the text and leaves only a handful of pages devoted to the typical lists of physical signs and their interpretations.

Physiognomic insight, Ibn 'Arabī tells us, has a divine compulsive quality. It also inspires fear because of "a natural fear of the soul departing the body." this fear, physiognomy is "a science that only occurs in the margins." "111 He also divides physiognomic insight into two kinds:

Some of these signs are natural, physical, and then it is the rational inclination of this physiognomic science, and others are spiritual, of the soul, which come from

\footnotetext{
${ }^{108}$ Askoy, "Arabic Physiognomy as a Link," 120.

${ }^{109}$ María Jesús Viguera Molíns, Dos cartillas de Fisiognómica (Madrid: Editoria Nacional, 1977), 17.

${ }^{110} \mathrm{Ibn}$ 'Arabī, Futūbāt, in Viguera Molíns, 31. All Ibn 'Arabī quotes translated from Viguera Molíns's Spanish translation.

${ }^{111}$ Ibn 'Arabī Futūbāt, 31. No ocurre esta ciencia sino entre marginados.
} 
faith, or the divine inclination. This is the light of God in the perceiving eye of the believer. $^{112}$

He continues by saying that he will address both sides for the reader.

Ibn 'Arabī goes into a great deal of detail on how the natural science part of physiognomic insight works:

Natural physiognomic insight allows one to know the man who does or says, acts or rests, [is] straight or deviant, then distinguish, after looking at the physiognomy or the organic constitution of anyone, if he is stupid, wise, clever, foolish, simple, licentious or otherwise, irascible or patient, vicious or not, impostor, wicked, honest, believer, impetuous or timid, etc., etc. ${ }^{113}$

This description matches Greek and other Islamic ideas about physiognomy fairly clearly, even if it devotes more lines to these ideas. However, in one sense he goes a bit further in linking humoral theory to physiognomy. He notes that some people have "defective processes [that] are radical in their temperamental and constitutional essence." $" 114$ These can be read in the body by noting

the prominence of the eyes, excessive sagging, having a very sharp or too thick nose, excessive pore dilatation or exaggerated whiteness or blackness, the very pronounced curl of the hair, its past smoothness, the strong concentration of the

\footnotetext{
${ }^{112} \mathrm{Ibn}$ 'Arabī, Futūbāt, 32. Unas de estas señales son naturales, físicas, y entonces es la vertiente sapiencial de esta ciencia fisiognómica, y otras son espirituales, anímicas, que son la Fe vienen, siendo entonces la vertiente divina, luz de Dios en el ojo de la Percepción del creyente.

${ }^{113}$ Ibn 'Arabī, Futūbāt, 33.

${ }^{114}$ Ibn 'Arabī, Futūbāt, 37. Algunos de estos procesos defectuosos son radicales en la escencia tempermental y constitucional.
} 
blue in the iris of the eye, its intense blackness or reverberation, and being able to continue by observing the imbalances in all the other organs, noting whether [the temperament] is a deviation towards one of its two extremes. ${ }^{115}$

In this way, instead of the physiognomic signs being read to reveal the humoral balance of the subject, most signs are themselves caused by the most serious humoral imbalances.

Nevertheless, it is the inclusion of the divinatory aspects of physiognomy that make Ibn 'Arabī’s physiognomy a bit more unusual than other Islamic examples. In this case, the spiritual insight comes from divine light that allows the person to perceive what the eyes cannot. ${ }^{116}$ The Andalucian even gives his reader a relatively thorough explanation of how this spiritual physiognomic insight works:

It can be someone who, just by seeing anyone's foot[print] on the ground, that is, a trace of him, without that person being present, is able to know if that footprint is that of a Blessed or a Damned, just as it occurs to the scout, [the] tracker, is able to deduce if a trace belongs to a white, one-eyed man, for example, describing his figure as if he saw it, also perceiving all those accidental things that have occurred in his composition, without seeing him directly; he may also rule

${ }^{115}$ Ibn 'Arabī, Futūbāt, 37. La prominencia de los ojos, o su hundimiento excesivo, o el hecho de tener una nariz muy afilada or demasiado gruesa, o la excesiva dilatacion de los poros o al revés, o la blancura o negritud exageradas, o la muy marcada rizosidad del pelo, o su lisura pasada, o la fuerte concentración del azul en el iris del ojo, o su intensa negrura o reverberación, pudiéndose seguir con otros desequilibrios en todo los demas organos, tomados como desviacion hacia alguno de sus dos extremos, segun adelantamos.

${ }^{116}$ Ibn 'Arabī, Futūbāt, 33. 
on family relations, and attribute a child to his father, should there be any disagreement, for lack of obvious resemblance, [it is] normal in such cases. ${ }^{117}$

In some ways this explanation is not unfamiliar because of the way that it reflects the preIslamic Arabian ideas of divination. The use of metaphor, using the examination of footprints by a tracker, to explain it recalls a common divinatory art. This is compounded by the inclusion of the fact that the spiritual practitioner can determine the parentage of a child, seemingly identical to the qiyāfa that allowed Muhammad's destiny to be read as an infant.

The theoretical portion of Ibn 'Arabī's chapter is followed by the expected list of signs and their meanings, but with the prefacing comment that physiognomy is "the patrimony of the initiates" but that he will do his best to list what physiognomers stipulate, test, and refer to. ${ }^{118}$ This note is followed first by a list of the physical traits of the body of the person who is the "harmonic ideal":

[The] harmonic structure [is] not excessive nor limited and restrained in flesh, neither fat nor thin in consistency. [It is] white with the sufficient diffusion of red and yellow, excellent hair, neither limp nor curly, and

\footnotetext{
${ }^{117}$ Ibn 'Arabī, Futūbāt, 34. Puede haber quien, con solo ver la pisada de cualquiera en el suelo, es decir, un rastro suyo, sin que tal persona esté presente, sea capaz de saber si esa huella es la de un Bendito o la de un Condenado, igual que le ocurre al ojeador, seguidor de pistas, capaz de deducir si una huella pertenence a un hombre blanco, y tuerto, por ejemplo, describiendo su figura como si la viera, percibiendo tambien todas aquellas cosas accidentales que en su contitucion se han producido, sin verle a él directamente; puede dictaminar asimismo sobre las relaciones familiares, y atribuir un hijo a su padre, caso de producirse en ello desacuerdo, por falta del parecido evidente, normal en esos casos.

${ }^{118}$ Ibn 'Arabī, Futūbāt, 41. Es patrimonio de iniciados.
} 
brown colored, without particular blackness, moderate in face, eyes of regular depth and darkness, considerable head, loosely hanging shoulders, symmetrical with the neck, perfect in the trunk, without fleshiness on the sides or in the thorax, clear voice, without hoarseness or elevations, allowing one to estimate its thickness in harmony; friendly, generous; without much wordiness, but neither [much] silence, using words when necessary; tending to the biliary and melancholic; eyes denoting happiness and contentment, normal hunger for riches, without pretending to judge or impose himself on anyone; neither hurried nor slow, fulfilling what wise men say when they express: "the most just and prudent, of the vicars of God, that is how our prophet Mohammad was created, God bless and save him, in order to contrast formal perfection, the same as in him, confirmed the perfection of hierarchy, being the best human being in all aspects, outside and in."119

For a science that tends heavily towards negative signs, it is notable to see this detailed and lengthy a portrait of moderation and balance. However, the fact that the ideal and good readings are based on moderation is something that continues the basic ideas of Greek physiognomy and thought in general. While it does not correspond to a people, as Polemon's ideal Greek description does, Ibn 'Arabī does tie this set of characteristics to Muhammad, the ideal Muslim.

The lists themselves cover less than four full pages, a fraction of the rest of the chapter. However, there is little here that is unusual other than its relative brevity. Ibn

${ }^{119}$ Ibn 'Arabī, Futūbāt, 41. 
'Arabī's list begins with the top of the body and then moves downward: hair, then forehead, eyes, nose, mouth, lips, teeth, face, temple, skin color, voice, movement, neck, belly, shoulders, back, shoulders again, arms, palms, fleshiness, foot, heel, legs, and then finally gait. The signs and readings are also fairly usual. For instance, moderately curly hair means bravery and mental health while smooth hair means cowardice, mental frailty, and poor acuity. ${ }^{120}$ One exception to this lack of notability is that Ibn 'Arabī tells us that the worst color of blue eyes are turquoise ones. ${ }^{121}$ Another is that he offers a set of signs and a reading for teeth: if the teeth are moderately smooth, with regular separations, the man is confident, loyal, and thoughtful. ${ }^{122}$

Ibn 'Arabī's work, then, is a bit unusual when compared to other Arabic works of physiognomy in terms of the larger type of work that it appears in. However, overall it represents the larger trends of medicalization and categorizing physiognomy as a science. He also lived in Al-'Andalus, or medieval Islamic Spain, which was the location of so many of the translations that were made from Arabic into Latin and vernaculars in the twelfth and early thirteenth centuries, a time period that roughly matches his lifespan. In that sense, he gives us a glimpse into the Islamic views on physiognomy as understood by the culture from which so many of the translations came to the universities of thirteenthcentury Europe, an area of the world that had largely forgotten Greek physiognomy by 1200.

${ }^{120} \mathrm{Ibn}$ 'Arabī, Futūbāt, 43.

${ }^{121}$ Ibn 'Arabī, Futūbāt, 43.

${ }^{122}$ Ibn 'Arabī, Futūbāt, 44. 


\section{Latin Rome and Physiognomic Consciousness}

The educated Latin Roman world was without doubt cognizant of the Greek body of theoretical and practical physiognomy works. After all, a well-educated Roman male was expected to read Greek. However, the Romans did not add much directly to this corpus, creating no known original works that can be definitely called physiognomy and only one epitomizing work in Latin. Instead, the classical Latin authors acquired and displayed what Elizabeth Evans called a physiognomic consciousness, a display of both general theories and individual descriptions that show a cultural familiarity with physiognomy. ${ }^{123}$

The epitome, the Physiognomy by Anonymus Latinus, is dated broadly to 250-400 CE. ${ }^{124}$ It is incomplete in its extant version, with 133 chapters remaining in the most complete manuscripts. The first chapter cites three Greek authors as the sources, stating, "I had at hand the books of three authors who have written on physiognomy, Loxus the physician, Aristotle the philosopher, and Polemon the orator, and I have chosen those parts which pertain to the main principles of the subject and which can be understood fairly easily." ${ }^{125}$ While the anonymous author offers little original contribution, the work is important because it offers some idea of the physiognomy of Loxus, a Greek physician

${ }^{123}$ Elizabeth C. Evans, "Physiognomics in the Roman Empire," The Classical Journal 45 , no. 6 (1950): 277-282.

${ }^{124}$ Ian Repath, Seeing the Face, 549.

${ }^{125}$ Anonymous Latinus, Physiognomy, in Seeing the Face, 557. Latin, 556. Ex tribus auctoribus quorum libros prae manu habui, Loxi medici, Aristotelis philosophi, Palemonis declamatoris, qui de scripserunt, ea elegi quae ad primam institutionem huius rei pertinent et quae facilius intelliguntur. 
and physiognomer, whose work is otherwise lost. ${ }^{126}$ The most important difference between Loxus and the other physiognomers, at least that which is understandable from the Anonymus Latinus, is that he thought the blood to be the seat of the soul. This assertion is stated most succinctly by the anonymous author in chapter two. ${ }^{127}$ The second chapter of the Anonymus Latinus also offers an explanation for how physiognomy works and what it offers, an explanation that synthesizes some of the Greek views: And so at first it needs to be established what physiognomy promises: it promises that it examines and perceives the quality of the mind from the quality of the body. Loxus, for example, established that the blood is the dwelling-place of the soul, and moreover that the whole body and the parts of it which give signs give different signs according to the liveliness or inertia of the blood and whether it is thinner or thicker or according to when it has free and direct or crooked and narrow channels. But others think that just as the soul is the shaper of the body, so the soul derives its appearance from the quality of the body, just like liquid in a small vessel which derives its appearance from the vessel and just like air breathed into a pipe, aulos, or trumpet: for although the breath is uniform, a trumpet, pipe, and aulos make different sounds. ${ }^{128}$

\footnotetext{
${ }^{126}$ Scholars have used the Anonymus Latinus's Physiognomy to glean what information they can about Loxus since at least the work of Foerster. See Geneva Misener, "Loxus, Physician and Physiognomist," Classical Philology, vol. 18, no. 1 (Jan., 1923): 1-22.

${ }^{127}$ Anonymous Latinus, Physiognomy, 557. Latin, 556. Et Loxus quidem sanguinem animae habitaculum esse constituit.

${ }^{128}$ Anonymous Latinus, Physiognomy, 557.
} 
The second view, that the soul is shaper of the body, is certainly much better accepted than the blood being the seat of the soul. However, the importance of finely distilled blood forming the pneuma in medical and psychological works may at least be related.

The anonymous author also holds that there are three types of physiognomy. The first is physiognomy based on the "established the characters of peoples and provinces and compared individuals with regard to their similarity to them."129 The second is physiognomy based upon body posture and facial expressions. ${ }^{130}$ The third is the bynow-familiar comparison to animals.

Nevertheless, the author is careful to explain that the most important aspect of physiognomy is not one of these three kinds of physiognomy, but instead is based upon the masculine and feminine. He states, "The primary division and distinction in this type of observation is the existence of a masculine type on the one hand and a feminine type on the other."131 Yet, he makes the point that masculine traits do not mean a male subject and feminine ones do not equal a female one. Instead there can be feminine signs found in male bodies and vice versa. Related to this is the association in Anonymus Latinus of the left side of the body with the feminine (if the members are larger on that side) and the right side of the body with the masculine. ${ }^{132}$ This intersection of masculine and feminine

${ }^{129}$ Anonymous Latinus, Physiognomy, 561. Latin, 560. nam primo gentium vel provinciarum propositis moribus ad similitudinem singulos quosque homines referebant.

${ }^{130}$ Anonymous Latinus, Physiognomy, 561. Latin, 560. Quo quis esset vultu vel in quo corporis statu per singulos animi sui motus.

131 Anonymous Latinus, Physiognomy, 557. Latin, 556. Prima igitur divisio observationis huius atque discretio ea est, ut alterum masculinum genus sit, alterum femininum.

${ }^{132}$ Anonymous Latinus, Physiognomy, 561. 
with physiognomy is joined by the use of animals in the eighth chapter. There the author divides a small list of exemplar animals into masculine and feminine. Masculine animals are the lion, wild boar, eagle, and hawk. The feminine examples are the leopard, deer, hare, peacock, partridge, and magpie. ${ }^{133}$

The actual chapters on animals are not included until the last dozen or so chapters. These include chapters on the horse, ass, ox, dog, ape, goose, wolf, tortoise, snake, owl, and cock. They also include three of the animals explicitly stated to correspond with masculine or feminine traits: the deer, lion, and peacock. All of the animal chapters have three parts: a description of the animal, a list of the identifying physical features in the human subject which correspond to the animal, and a list of the character attributes of the human subject who has these shared physical traits.

The transition between the first and second parts of these chapters uses the formulaic ad huius animalis speciem homines qui referuntur, or "men who correspond to this type of animal." This is true of even the chapters on the feminine deer and peacock. For instance, in the case of the deer, "Men who are referred to this type of animal will be long, with narrower limbs, large cheeks, and will walk quickly: they are also easily provoked to anger, have a small mind, are fickle, impetuous, and excessively keen and ineffectual."

The only exceptions to this are the tortoise and owl chapters. In this case it is a woman who is given as the referent. For instance, in the tortoise chapter: "Any woman who is referred to this type of animal is as follows: she has a short neck, a broad back,

${ }^{133}$ Anonymous Latinus, Physiognomy, 561.

${ }^{134}$ Anonymous Latinus, Physiognomy, 631. 
broad feet, a wrinkly face and very wrinkly cheeks. A woman of this sort is useless, ineffectual, and unpleasing.",135

The chapters on the bodily members are fairly standard and based largely upon Polemon. Also, despite the insistence that it is one kind of the three types of physiognomy, there is almost no elaboration on geographical physiognomy. The last two chapters, 132 and 133, are worth briefly discussing. Chapter 132 is a short explanation of how a practitioner should perform physiognomy using the provided signs. It contains the usual admonition that many men will have the characteristics of more than one animal and offers this example of how to handle such a situation: "For if it happens that the signs of the horse and the ape coincide, you will not hesitate to assign to the same man both the insolence of the horse and the malice of the ape."136 The author also advises the physiognomer to be aware that all men will do what they can to prevent their fault from being exposed, noting that "both culture and society obscure human characters.",137

The final extant chapter begins to address the predictive possibilities of physiognomy, specifically through some of the examples cited by Polemon from his travels to Samos. However, because it is incomplete, we do not know what the anonymous author had to say about this possibility, nor what Loxus might have said about it.

Today there are fifteen surviving manuscripts of the Anonymus Latinus, dating from the twelfth through fifteenth centuries. Of these, only seven are considered good

${ }^{135}$ Anonymous Latinus, Physiognomy, 633.

${ }^{136}$ Anonymous Latinus, Physiognomy, 635.

${ }^{137}$ Anonymous Latinus, Physiognomy, 635. 
enough to consult, with the others suffering from "being partially epitomized, corrupt, lacunose, or badly copied." ${ }^{\prime 38}$ There is also a now-lost manuscript that was the source of Du Moulin's editio princeps in $1549 .{ }^{139}$ There is no real evidence for the Anonymus Latinus being used prior to the twelfth century, making its history prior to 1100 as murky as its beginnings.

Instead, what we know of physiognomy in the Latin Roman world comes largely from the research begun by Elizabeth Evans. Her work found various examples of physiognomy or physiognomic consciousness in the works of classical Latin authors. For instance, in Cicero's ars rhetorica she noted that he emphasizes actio and pronuntiatio as much as the words chosen, because "the countenance" was "the image of the mind." This idea was one that Evans argued for as an example of Roman physiognomic consciousness because of its direct link between mind and face. Then, in Seneca's De Ira, she pointed to his description of the angry man:

But you have only to behold the aspect of those possessed by anger to know that they are insane. For, as the marks of a madman are unmistakable - a bold and threatening mien, a gloomy brow, a fierce expression, a hurried step, restless hands, and altered color, a quick and violent breathing — so likewise are the marks of the angry man. ${ }^{140}$

While this description is dealing more with the passions than with the innate soul, the careful linking of a list of outward characteristics to an inner state of the mind is quite

\footnotetext{
${ }^{138}$ Repath, 552.

${ }^{139}$ Repath, 552.

${ }^{140}$ Evans, "Physiognomics in the Roman Empire," 278.
} 
close to physiognomy. Evans also saw this physiognomic consciousness in Suetonius's Lives. While she notes that "exact parallels or precise interpretations" from the Greek works are impossible to find, she still sees physiognomic consciousness in his description of the "inspector of foreheads" hired to foretell Britannicus's future. ${ }^{141}$ Additionally, in Suetonius's portraits of the Roman emperors, he emphasizes those physical characteristics that correspond to the qualities he wanted to draw attention to in the emperor's natures. The connections between physical attributes and natures correspond with those readings outlined by Polemon and Pseudo-Aristotle. ${ }^{142}$

These small examples within the early Latin tradition begin to form a solid foundation for an argument for a physiognomic consciousness. There are many further examples from pagan Latin authors that support the basic theory of physiognomy. For instance, Pliny the Elder (23-79), in his Naturalis Historia, writes:

Nobody has eyes of only one colour; with everyone the general surface is white but there is a different colour in the middle. No other part of the body supplies greater indications of the mind. This is so with all animals alike, but specially with man, that is, indications of self-restraint, mercy, pity, hatred, love, sorrow, joy. The eyes are also very varied in their look — fierce, stern, sparkling, sedate, leering, askance, downcast, kindly: in fact the eyes are the abode of the mind (animus). ${ }^{143}$

${ }^{141}$ Evans, "Physiognomics in the Roman Empire," 279.

${ }^{142}$ Evans, "Physiognomics in the Roman Empire," 280.

${ }^{143}$ Pliny, Natural History Volume I: Books 1-2, 11.145-146, trans. H. Rackham, Loeb Classical Library 330 (Cambridge, MA: Harvard University Press, 1938). 
As we have seen, the eyes are the considered to be the most important sign in Greek physiognomy. Pliny's emphasizes their being the home of the animus and therefore the best sign of a person's inner life. In another similarity to the Greek physiognomers, Pliny still allows for the rest of the body to supply "indications," which indeed appears to further reveal a familiarity with physiognomy texts, or, at the very least, more than superficial knowledge of the basic ideas.

However, Pliny was not an ardent supporter of physiognomy. Indeed, in chapter 114 of his Naturalis Historia he writes of his surprise that someone as learned as Aristotle would subscribe to the idea that the body could be read in order to prognosticate the subject's long life or lack thereof. Clearly then, Pliny is familiar with the PseudoAristotelian physiognomy in some form and feels the need to at least address it, even if he never calls it by name, but instead refers to it as praescita. ${ }^{144}$

Despite his reluctance to even discuss practices that could be labeled physiognomy, Pliny is persuaded to do so briefly by the authority of the Roman Historian Gnaeus Pompeius Trogus (fl. $1^{\text {st }}$ century BCE), whose works, including a natural history, are all lost to us except in excerpt. Indeed, one of those excerpts is in Pliny's chapter 114. The excerpt still contains no reference to the term physiognomy or its theoretical underpinnings, but it is without a doubt a list of readings of different kinds of facial body parts. For example, the forehead, if broad, signifies an underlying sluggish mind. If small, the owner has an unsteady disposition. If rounded, the subject has a bad temper.

\footnotetext{
${ }^{144}$ Pliny, Natural History, ch. 114, Miror equidem Aristotelem non modo credidisse praescita vitae esse aliqua in corporibus ipsis.
} 
Similar readings are given for different sorts of eyebrows and the eyes. ${ }^{145}$ In this manner Pliny goes somewhat beyond Evans's idea of physiognomic consciousness, even if reluctantly and without theory or its Greek or Greek-derived name.

As another example, a larger study of Cicero's De Officiis has explored the influence of physiognomy on that work through the conduit of Panaetius of Rhodes (185110 BCE). Panaetius, a Stoic philosopher, agreed with the physiognomic connection of the physical body and the soul or mind. However, he did not agree with "its assumption of fixed character-types," instead choosing to believe that man is inherently good and only needs a guide to discover how to change his behavior to match his inherent goodness. ${ }^{146}$ It was apparently this idea that influenced Cicero's discussion of decorum, something that he argues all men are capable of attaining, at least ideally, because of such inherent goodness. $^{147}$

There are many more examples of physiognomic consciousness in Latin works that are more literary and less theoretical, such as Apuleius (125-170) in his Metamorphoses 2.2. The line "et cetera corporis execrabiliter ad amussim congruentia" is most often translated as if it means that Lucius merely resembled his mother. However, recent work argues that it can be translated so that the rest of his bodily features “correspond" to his mother's upstanding character (probitas) instead, a much more physiognomically conscious interpretation. One scholar goes so far as to see in the

\footnotetext{
${ }^{145}$ Pliny, Natural History, ch. 114. The Latin for the three readings is "segnem animum subesse," "mobilem," and "iracundum."

${ }^{146}$ Andrew R. Dyck, A Commentary on Cicero: De Officiis (University of Michigan Press, 1996), 245.

${ }^{147}$ Dyck, A Commentary on Cicero, 245.
} 
character Byrrhena's portrait of Lucius not just a collection of signs, but an emphasis on the positivity of the mean (medietas). ${ }^{148}$ This idea of the mean does indeed correspond with the moderation often seen in the positive physiognomic signs found in the Greek sources, though most signs in physiognomic lists point to something negative. In a similar literary example, physiognomic consciousness can be detected in the work of Ovid (43 BCE-17 CE), who says of Lucretia, "Her face was worthy of its peer, her soul." $" 149$

Another example in support of physiognomic consciousness is the way that classical sources treat the phenomenon of the double pupil (pupula duplex). Because the double pupil was considered evidence of evil eye or a person capable of casting it (jettatore), a number of Latin sources address the issue. ${ }^{150}$ Although the double pupil does not make an appearance on lists of physiognomic signs, it does fit with the general theory behind physiognomy of a correspondence between an inner nature or soul and the physical appearance of the eyes.

However, the examples of the evil eye in Latin discussions match a specific form of physiognomy, the so-called geographic physiognomy, which focuses on the physical traits associated with an ethnic group. In a manner similar to Polemon's descriptions of the various people he meets in his travels who display all the negative traits of their

\footnotetext{
${ }^{148}$ Hugh J. Mason, "The Metamorphoses of Apuleius and its Greek Sources," in Latin Fiction, ed. Heinz Hofmann (Routledge, 2004), 307-308.

${ }^{149}$ Ovid, Fasti 2.758: et facies animo dignaque parque fuit, in Antón Alvar Nuño, . "Ocular Pathologies and the Evil Eye in the Early Roman Principate," Numen, vol. 59 (2012): 307-308.
}

${ }^{150}$ Antón Alvar Nuño, "Ocular Pathologies and the Evil Eye in the Early Roman Principate.” Numen, vol. 59 (2012), 295-321. 
homelands, Pliny the Elder provides descriptions of certain peoples. For instance, he sees the double-pupil concentrated in certain groups. These groups include the Triballi and the Illyrians, who "have two pupils in each eye," and the Bitiae women of Scythia, who have the "distinguishing marks" of the double pupil. ${ }^{151}$

A less direct, but still powerful, clue to the importance of physiognomy in the Latin world can be found in Roman portraits. Torill Christine Lindstrøm performed an analysis of the "facial emotional expressions/facial emotional displays, [which] can be studied systematically." "152 Using the Facial Action Coding System (FACS), Lindstrøm used facial anatomy to make assessments of each muscular unit of the face, looking for 24 “Action Units" or AUs. Her results found very few AUs among depictions of Roman men, mostly in the brows, and these were of the lowest intensity. These results are in direct opposition to the Etruscan art that preceded the Roman portraits and the Hellenistic art around the Mediterranean, with the only exception being expressive Roman theatrical masks. ${ }^{153}$ Lindstrøm's results hold weight for physiognomic consciousness because of the reasons for this Roman restraint. If the ideal Roman pater familias was supposed to display severitas, gravitas, dignitas, and honor, then he must display "controlled and dignified behaviour."154 This portrayal seems to support a physiognomic consciousness,

${ }^{151}$ Pliny, Natural History, 7.16-18. While he does not compare this to Polemon, see Alvar Nuño for a discussion of the use in Pliny, 299.

152 Torill Christine Lindstrøm, "Facial Expressions (and non-Expressions) in Roman Faces," Bollettino di archeologia online, special proceedings volume from the International Congress of Classical Archeology: Meetings Between Cultures in the Ancient Mediterranean (2008): 87.

${ }^{153}$ Lindstrøm, "Facial Expressions," 89.

${ }^{154}$ Lindstrøm, "Facial Expressions," 89. 
a desire to portray the ideal of a nature that was inclined to be virtuous, rather than given to the passions. Giving in to the passions was to be expected from actors, who were often of the lowest classes, because they were not expected to be able to overcome them. Instead of resisting their passions like virtuous Roman men, they were expected to give into them.

The early pagan Latin examples are not the only early ones. There are also examples of a physiognomic consciousness in early Christian sources. In the eastern Mediterranean, physiognomy was a tool used by Philo of Alexandria (c. 25 BCE - c. 50 $\mathrm{CE}$ ), a Jewish scholar who exerted considerable influence on Biblical interpretation among subsequent Christian authors. ${ }^{155}$ Philo's commentary on the Pentateuch used physiognomy as an analogy for allegorical interpretation, a way of "moving from the outside in by means of careful observation." ${ }^{, 156}$ This allegory meant that the law books of the Old Testament have both body and soul, with the literal words a body that had to be read for the soul, or allegorical meaning, which lies beneath the surface.

The Alexandrian Christians Clement (150-215) and Origen (184-253) shared this physiognomic awareness. However Clement used it as a tool to discredit pagan prophets, "thieves and robbers," which the Scripture "predicated for the most part from observation and probabilities, as physiognomizing physicians judge from natural signs." ${ }^{, 157}$ In other

${ }^{155}$ For instance, Philo is important in the Christian understanding of Moses. See Louis H. Feldman, "Philo's View of Moses' Birth and Upbringing," Catholic Biblical Quarterly 64 (2002).

${ }^{156}$ David Lincicum, "Philo and the Physiognomic Tradition," Journal for the Study of Judaism, 44 (2013): 68.

${ }^{157}$ Clement, Strom. 1.21.135. In Lincicum, "Philo and the Physiognomic Tradition," 65. 
words, Christians could by observation "read" non-Christians claiming to be prophets in order to discredit them, a useful tool in any inter-faith theological debate. Origen, on the other hand, uses physiognomy as part of an explanation for the incarnation of Christ, saying,

Suppose that the views of the physiognomists are granted, of Zopyrus, Loxus, or Polemon, or anyone else who wrote about these matters and professed to possess some remarkable knowledge, that all bodies conform to the habits of their souls; then for the soul that was to live a miraculous life on earth and to do great things [i.e., Jesus], a body was necessary. ${ }^{158}$ Origin did not just use physiognomy as a tool, but also named famous physiognomers as examples. While all of these men were a part of the Greek-speaking eastern half of the empire, their works would become widely accepted in the Middle Ages, making their physiognomic consciousness available to medieval thinkers.

Another example of physiognomic consciousness in early Christian sources can be found in verbal descriptions and visual depictions of Paul. The only early written description of Paul comes from the apocryphal Acts of Paul and Thecla.

At length they saw a man coming (namely Paul), of a low stature, bald (or shaved) on the head, crooked thighs, handsome legs, hollow-eyed [some translations read: with eyebrows meeting]; had a crooked nose; full of

${ }^{158}$ Origen, C. Cels. 1. In Lincicum, "Philo and the Physiognomic Tradition," 65. 
grace; for sometimes he appeared as a man, sometimes he had the countenance of an angel. ${ }^{159}$

The description of Paul as bald continues in third-century catacomb art, though the Middle Ages, and on into modern depictions. However, in its original form, there was a deeper, physiognomic meaning to this description, because in it Paul resembles an ideal general. Many are familiar with the military metaphors in Paul's writings, but fewer with his use of the adlocutio or general's exhortation speech. This, combined with the similarities between the description of Paul and Suetonius's description of Caesar a man "of small stature with a crooked nose and a unibrow," emphasize the likelihood that the author of The Acts of Paul and Thecla was likely drawing out the military connections made by Paul in his own writings by drawing upon the physiognomic consciousness of what a good general would look like. ${ }^{160}$

There is also a connection between physiognomy and hagiography in the early Christian period. In the early literature about pilgrimages to see the living saints of the deserts, Georgia Frank found that these late antique texts developed their own “meaningful physiognomy” for themselves. ${ }^{161}$ This reimagining of physiognomy was attempted for the practical reason of learning how to recognize the presence of the sacred

${ }^{159}$ The Acts of Paul and Thecla, 1.7, Trans. J. Jones. In Laurie Brink, "Picturing Paul: The Good General Addressing His Troops," in The Bible Today, 281. Also, see Harry O. Maier, Picturing Paul in Empire: Imperial Image, Text and Persuasion in Colossians, Ephesians and the Pastoral Epistles (A\&C Black, 2013).

${ }^{160}$ Brink, "Picturing Paul," 282.

${ }^{161}$ Georgia Frank, The Memory of the Eyes: Pilgrims to Living Saints in Christian Late Antiquity (Berkeley: University of California Press, 2000), 130. 
when looking at ascetic faces. ${ }^{162}$ For instance, Athanasius (296-373) in his Life of St. Anthony wrote,

His face had a great and marvelous grace... It was not his height or broad build that distinguished him from the rest, but the stability of character and the purity of his soul. His soul being free of confusion, he held his outer senses also undisturbed, so that from the soul's joy his face was cheerful as well, and from the movements of the body it was possible to sense and perceive the stable condition of his soul, as it was written, When the heart rejoices, the countenance is cheerful; but when it is in sorrow, the countenance is sad. (Prov. 15:13). ${ }^{163}$

This passage certainly can be read to contain a physiognomic consciousness of the connection between a person's physical appearance and soul. However, the Christianized physiognomy, or what Frank calls "a biblicalized physiognomy," is actually part of what removes most of the individual details from verbal portraits of saints. ${ }^{164}$ For instance, in the final chapter of the History of Monks, John of Diolcos "was the father of hermitages. He, too, was endowed with much grace. He looked like Abraham and had a beard like Aaron's." ${ }^{\prime 165}$ The fact that some early Christian sources began to judge sanctity according to which biblical figure or group of figures a saint resembled brings to mind the earlier

${ }^{162}$ Frank, The Memory of the Eyes, 137.

${ }^{163}$ Athanasius, Vita Antonii, trans. Robert C. Gregg in Athanasius: The Life of Saint Anthony (New York: Paulist, 1980), 81.

${ }^{164}$ Frank, The Memory of the Eyes, 163.

${ }^{165}$ Frank, 163. 
Greek method of finding the animal or group of animals a man most represented. Both methods involve classification to some extent (i.e. which character each animal or biblical figure possessed) and the reading of a subject according to which animal or biblical figure he most resembles.

This biblicized physiognomy is taken one step further by Sulpicius Severus (363425), author of The Life of Martin of Tours. Sulpicius wrote a letter to the deacon Aurelius in which he described a vision of St. Martin:

Suddenly I seemed to see St. Martin appear to me in the form of a bishop, clothed in a shining white robe, with a countenance like fire, eyes like stars, and glittering hair. He appeared to me with the features and bodily form which I had known, so that I find it almost difficult to say what I mean - I could not fix my eyes upon him, though I could clearly recognize $\operatorname{him}^{166}$

Instead of looking like Abraham and Aaron, St. Martin's physical appearance is likened to the heavens, full of fire, stars, and glitter. This description is clearly many steps removed from the Greek physiognomic theoretical works and handbooks and can only be called an example of physiognomic consciousness in the loosest possible interpretation of that term. Visual signs are being used as proof of saintliness, but they are well beyond any attempt at connection to science, medical or otherwise. Instead, they appear to be more a part of religious semiotics.

${ }^{166}$ Sulpicius, The Life of Saint Martin trans. Rev. Alexander Roberts, in Mary-Ann Stouck, Medieval Saints (University of Toronto Press, 1999), 160. 
However, early Christian writings sometimes had a more traditional physiognomic consciousness. For instance, Lactantius (ca. 260-340), professor of rhetoric and later tutor to Constantine's son Crispus (d. 326), wrote about Galerius (260311) in his The Deaths of the Persecutors:

A natural barbarism was inherent in this beast, a savagery alien to Roman blood. Nor was this strange, since his mother, a woman from the other side of the Danube, had fled into new Dacia by crossing the river when the Carpians were infesting the land. His bodily appearance was in keeping with his character: towering in stature and massive in corpulence, he was swollen and spread to a horrible magnitude. With voice and action and appearance, he struck fear and terror into all. ${ }^{167}$

Note that, while not strictly physiognomic, this single example contains almost all the kinds of physiognomic signs available. First, it likens Galarius to a "beast." Second, it lists individual features such as stature and even the voice. Third, it associates a certain character to a geographical group, those "from the other side of the Danube," much as Polemon did with the Sythians, etc. Additionally, just as Polemon's geographical signs are followed with a story to prove the correctness of the author's judgment, so Lactantius's description confirms his judgment of Galerius, noting that even Diocletian (244-311) was afraid of Galerius because he used "the tricks which it is the custom for barbarians to use in conducting war with their own peoples."168

${ }^{167}$ Lactantius, The Deaths of the Persecutors, 9. In Bart D. Ehrman and Andrew S. Jacobs, Christianity in Late Antiquity: 300-450 C.E. (Oxford University Press, 2004), 13. ${ }^{168}$ Lactantius, The Deaths of the Persecutors, 9. 
Another more traditional Roman physiognomic consciousness is found in the travel journal of the Iberian or Gallic pilgrim Egeria (c. 381), who journeyed to the deserts of Egypt and the Holy Land. Egeria's account has almost no physical descriptions of the numerous bishops, deacons, and monks she meets. However she does have one interesting description of a pair of portraits. While in Edessa, she spoke with the bishop there:

[The] holy bishop of that city, a truly religious man, a monk and a confessor who received me generously, said to me: "Since I see, daughter, what great trouble you have imposed upon yourself for the sake of religion, such that you have come to this place from the other end of the world, if you like, we shall show you all the place that Christians find pleasing to see." First giving thanks to God and then to him, I eagerly asked him to see fit to do as he said. So he guided me first to the palace of King Abgar; there he showed me a huge marble portrait of him, which they said was a good likeness, as shiny as if it were made from pearl. Standing opposite, it appeared from Abgar's face that this man had been quite wise and honorable. The holy bishop said to me, "This is King Abgar, who before he saw the Lord, believed that he was truly God's son." Next to it there was also another similar portrait made out of the same marble, which he said was of his son Magnus, and he also had a certain charm in his face. ${ }^{169}$

\footnotetext{
${ }^{169}$ Egeria, Travel Journal, From Égérie: Journal de voyage (Itinéraire) et Lettre sur la Béatissime Égérie, ed. Pierre Maraval, trans. Andrew S. Jacobs (Paris: Cerf, 1982).
} 
Thus, Abgar (d. c. 40CE), reputedly one of the first Christian kings in history, and his son Magnus were identified as wise, honorable, and even charming from just their marble portraits. Egeria is even careful to point out that she was assured that it was a "good likeness."

While it would be possible to argue quite easily and strongly against any single one of these examples of physiognomic consciousness that scholars have pulled from classical Latin and early Christian sources, it is much more difficult to argue against all of them. Instead, what could have been a coincidence or chance occurrence once or twice becomes a gradually reinforced pattern, demonstrating that Elizabeth Evans was correct. The Mediterranean did have an acquaintance with and understanding of physiognomy, even if Roman Latin authors were not writing theoretical treatises or even handbooks dedicated to the subject and Christian Romans were modifying that consciousness to suit their needs.

\section{The Early Middle Ages and Physiognomy}

As the western empire disintegrated economically and administratively, so did Latin knowledge of Greek sources, including those treating physiognomy. A generation after the attempts of Boethius to translate what he could of Greek philosophy into Latin, there were few intellectuals in Latin Christendom who studied Greek much less Greek texts. The physiognomies of Polemon, Pseudo-Aristotle, and their epitomizers were lost for almost a millennium to Christian Latin intellectuals. 
Once the Greek physiognomic sources were beyond reach, what was left to medieval thinkers was access to the Latin works reflecting the Roman physiognomic consciousness. However, there is very little to directly point to in the early Middle Ages that reflects an understanding of physiognomy on the level of Pliny, Cicero, and Origen. Yet, I would argue that the careful study of the texts that displayed this consciousness could easily have left, and probably did leave, a sort of subconscious receptivity to physiognomy. However, this reflection of a reflection was far enough removed from the Greek texts that it is largely impossible to pinpoint exact parallels or use of the term physiognomy.

Let us take, for example, the Etymologies of Isidore of Seville (560$636 \mathrm{CE})$. While his supposedly great knowledge of Hebrew and Greek probably extended to only a few phrases or words, Isidore did display a knowledge of classical Latin works, such as Martial's Epigrams, Tertullian's On Spectacles, and even Pliny the Elder's Natural History. ${ }^{170}$ Therefore, Isidore likely developed a natural receptivity to ideas making connections with physiognomy, though he was unaware of most of the connections.

For instance, in Book XI, "Concerning the human being and portents" (De homine et portentis), Isidore shares the most basic view of the role of soul and body necessary for physiognomy to be compatible. He writes, "Human beings have two aspects: the interior and the exterior. The interior human is the soul [and] the exterior is the body.... [The

${ }^{170}$ See "Life and Works," introduction to Isidore of Seville's Etymologies, trans. and intro. by Stephen A. Barney, W. J. Lewis, J. A. Bach, Oliver Berghof (Cambridge University Press, 2006), 7. 
mind is] the superior part in the soul." $" 171$ While this is a rather generic and flat description of the connection between body and soul, Isidore goes further later in the same book. He claims that

facial expression (vultus) is so called because the inclination (voluntas) of the will is displayed by it. The expression changes in various movements according to the will, whence the two terms for the face differ from each other, for while the face refers simply to someone's natural appearance, facial expression reveals what is on his mind. ${ }^{172}$

Unpacking this statement does not reveal immediate knowledge of physiognomy or even complete compatibility with it, but it does show a continued willingness to associate the physical outer person with his or her inner thoughts and feelings. It also corresponds with the physiognomy of expressions that Pseudo-Aristotle's Physiognomy warned were the least reliable.

Isidore also emphasizes the connection between the eyes and soul, although, again, not in a strictly physiognomic way. The forehead and eye-sockets, he writes, are "a kind of likeness of the soul [and express] the movement of the mind, whether it is joyful or sad, through its own look." ${ }^{\prime 73}$ As for the eyes themselves, "among all the sensory organs, they are closest to the soul."174 And so, while Isidore does go through

${ }^{171}$ Isidore of Seville, Etymologies, i. 6-7, trans. and intro. by Stephen A. Barney, W. J. Lewis, J. A. Bach, Oliver Berghof (Cambridge University Press, 2006), 231.

${ }^{172}$ Isidore, Etymologies, XI. i. 34, 233.

${ }^{173}$ Isidore, Etymologies, XI. i. 35, 233.

${ }^{174}$ Isidore, Etymologies, XI. i. 35, 233. 
the human body member by member, he does not do so in such a way as to present any real physiognomic theory, inclusion of physiognomic signs, or even Roman consciousness of it. Even when he discusses portents, specifically people with actual animal body parts [i.e. the Minotaur], he offers no physiognomic signs for animal likenesses in humans, thereby showing no knowledge of one of the major categories of physiognomic signs in Greek works. ${ }^{175}$

A brief survey of Book XII of the Etymologies, with the same De animalibus title as Albertus Magnus's main physiognomic work, delivers similar results, but with a few exceptions. In his numerous entries for animals he is more concerned with the titular etymologies of the animals' names than any other topic. There are virtually no physiognomic signs, and the descriptions favor physical characteristics over animal temperaments or natures. However, there are a few exceptions. Among livestock and beasts of burden, the doe and the hare are "timid."176 The ox gets a more unusual description of an affectionate and loyal nature: "Oxen possess an extraordinary affection for their comrades, for one will seek the other with whom he has been accustomed to share the yoke, and with constant lowing show its devoted fondness if by chance the other is missing."177 Among animals there are also some more negative natures. Buffalo are so wild that they are "ungovernable," and the wild ass is so "jealous" that when male colts are born, the grown male herd leader (onager) will "bite off their testicles." ${ }^{178}$ The

${ }^{175}$ Isidore, Etymologies, XI. iii. 9, 244.

${ }^{176}$ Isidore, Etymologies, XII. i. 21 and 23, 248.

${ }^{177}$ Isidore, Etymologies, XII. i. 30, 249.

${ }^{178}$ Isidore, Etymologies, XII. i. 33 and 39, 249. 
wolf is also clearly the owner of a negative nature, for it "is a violent beast, eager for gore." 179

Horses get some extra attention from Isidore, taking up a great deal more space in his entries than most animals. Not only do they "have a great deal of liveliness," but they also show great loyalty and affection because "many of them shed tears when their master dies or is killed, for only the horse weeps and feels grief over humans." ${ }^{180}$ While horses do not get a physiognomic treatment, meaning there is no real list of physical attributes to look for in horses that are proof of specific temperaments, Isidore does hint that there is an ideal type of horse in form, beauty, quality, and color, that is not unlike an ideal physiognomic description of a man, with especially chestnut (badium) color denoting the best type horse for speed. ${ }^{181}$

However, the clearest example of a subconscious receptivity to physiognomy can be found in Isidore's discussion of lions, which are the most positive of physiognomic likenesses in humans in the Greek tradition. Lions, for Isidore, are similarly noble, attacking humans only when hungry, and honorable, not attacking prone creatures. But more importantly, lions are

of three types. Of these the small ones with curly manes are peaceful, and the long ones with straight manes are fierce. Their foreheads and tails reveal their spirit. Their strength is indicated in their chest, their

${ }^{179}$ Isidore, Etymologies, XII. ii. 24, 253.

${ }^{180}$ Isidore, Etymologies, XII. i. 43, 249.

${ }^{181}$ Isidore, Etymologies, XII. i. 45-47, 250. 
steadfastness in their head. When surrounded by hunters they look at the ground so as not to be frightened by the sight of hunting spears. ${ }^{182}$

These are almost entirely physiognomic ideas applied to an animal. Size, texture of mane hair, and the shape of the head, forehead, and tail are all clues to their natures. These are even varying natures, with lions being capable of being peaceful or fierce, thereby offering a sort of spectrum of possible natures instead of a single, defined nature for the whole species. Yet, despite these echoes of physiognomy, they were little more than echoes, and strong echoes such as those in Isidore's words on lions were rare.

Isidore's near contemporary Gregory the Great (540-604) has an even fainter echo. In his Regula Pastoralis he does note that temperament, and not outward circumstances, causes some people to become happy or sorrowful. We must impress on them that certain vices accompany certain temperaments. The happy tend toward dissipation, the sorrowful toward anger. All of us, then, must consider not only the temperament we have to live with, but the worst things it exposes us to; when we fail to fight our moods we may succumb to vices from which we thought were free. ${ }^{183}$

The chance that this shows a physiognomic consciousness seems to increase with a glance at the subjects of his chapters on the kinds of men that priests must care for: the meek and the irascible, the humble and the proud, the indolent and the impulsive, the

${ }^{182}$ Isidore, Etymologies, XII. ii. 4, 251.

${ }^{183}$ John Leinenweber, trans, Pastoral Practice: Books 3 and 4 of the Regula Pastoralis by Saint Gregory the Great (Harrisburg, PA: Trinity Press International, 1998), 8. 
guileless and the devious, among others. However, the chance of this being more than a whisper of any sort of physiognomic consciousness disappears once the chapters are examined intensively. The descriptions of these types of people are almost devoid of physical traits. The closest Gregory comes to anything physiognomic in these descriptions is when he discusses devious people and Isaiah 34:15. He writes:

As if he were talking to Judah, the prophet spoke out against those sinning and excusing themselves when he said, "There the hedgehog had its hole." The hedgehog represents the duplicity of the devious, who cunningly defend themselves. When you catch a hedgehog you see its head, its feet, and its whole body, but as soon as you grab it it rolls up into a ball, draws its feet and hides its head; its entire being, all of which you saw a moment before, is lost in the hands of the person holding it. Such indeed, such are the devious when they are caught in their transgressions.

Even this likeness of a person to an animal is behavioral and not based upon the physical characteristics of the person. Instead, the comparison of man to hedgehog is most likely elaborate metaphor.

The Carolingian period shows the completion of the gradual change to a subconscious receptiveness from the earlier physiognomic consciousness. For example, Einhard (775-840) created a famously awkwardly placed portrait of Charlemagne's physical appearance in his Life of Charlemagne. He wrote:

His body was large and strong; his stature tall but not ungainly, for the measure of his height was seven times the length of his own feet. The top of his head was round; his eyes were very large and piercing. His nose 
was rather larger than is usual; he had beautiful white hair; and his expression was brisk and cheerful; so that, whether sitting or standing, his appearance was dignified and impressive. Although his neck was rather thick and short and he was somewhat corpulent this was not noticed owing to the good proportions of the rest of his body. His step was firm and the whole carriage of his body manly; his voice was clear, but hardly so strong as you would have expected. ${ }^{184}$

This description contains the kind of details of physical appearance that seem to lend themselves to physiognomic judgment, one that could perhaps be linked to a physiognomic consciousness. However, the details that Einhard lists are a combination of either very general or completely opposite what a positive physiognomic reading would have required for the adherents of Polemon or Pseudo Aristotle, making it quite unlikely that this is more than a weak echo of physiognomic consciousness, at best.

The "large" eyes that Einhard notes were a sign related to lethargy and cattle by Pseudo-Aristotle. ${ }^{185}$ For Polemon, Charlemagne's “corpulent" stomach was a sign of either drunkenness and "love of sexual intercourse" if the belly drooped, or "wickedness of deeds, malice, deceit, cunning, and a lack of intellect" if the large belly was "very fleshy and strong." ${ }^{186}$ Polemon also noted that a thick and short neck together "indicate a strong body" but "cowardice in the soul." Surely none of these are connotations that

\footnotetext{
${ }^{184}$ Einhard, Life of Charlemagne, trans. A.J. Grant (Cambridge, Ontario: Parentheses Publications, 1999), 19-20.

${ }^{185}$ Pseudo-Aristotle, Physiognomy, 657.

${ }^{186}$ Polemon, Physiognomy, 405.
} 
Einhard would have wanted to include in his portrait of his emperor if he had known of them. Such a negative physiognomic reading even removes this from a physiognomic consciousness.

In general, then, physiognomy transferred into physiognomic consciousness, then weakened into vestiges, then disappeared. However, one small exception to this overall trend is in the work of John of Salisbury (1120-1180). His Policraticus, a work of advice for kings and those in various positions of power, is often pointed to as one of the most important medieval examples of political ethics. In the fifth book of his eight-book work, John introduces a chapter on "What is pertinent to the duty of a Preconsul," or the matters pertinent to rulers and "ordinary" judges along with the ethics of gifts according to the authority of classical and medieval authors. ${ }^{187}$

In this seeming hodgepodge of a chapter, in the midst of a discussion of the proper demeanor of judges, there are three small inclusions worth note. First, John tells us explicitly that he has read, or become acquainted with, Pliny's Natural History. ${ }^{188}$ Next he retells the story from Pliny of the Bitiae women of Scythia who have two pupils per eye and therefore also a special ability to use the evil eye. ${ }^{189}$ However, John attributes the story to Appollonides instead of Pliny. Third, after the discussion of

${ }^{187}$ Policratus: sive De nugis Curiarlium, \&vestigiis Philosophorum, Lugduni Batauorum, Ex officina plantiniana, Apud Franciscum Raphelengium, (1595). Full title: Quae pertineant ad religionem Preconsulum, prafidu, \& ordinariorum iudicunt; \& quatenus Xenia protendi liceat; \& de Cicerone, Bernardo, Martino, Gaudfrido Carnotensi.

${ }^{188}$ Policratus: sive De nugis Curiarlium, \&vestigiis Philosophorum, Lugduni Batauorum, Ex officina plantiniana, Apud Franciscum Raphelengium, (1595), 263. in libro naturalis historiae apud Plinium didici.

${ }^{189}$ Policratus, 263. in Scythia nasci feminas, quae Bithiae vocantur 
"monstrous" judges and evil eyes, he relates that physiognomers reveal to us that those with spotted eyes are inclined toward wickedness. ${ }^{190}$ It is a very short reference to physiognomy, but it is direct, with the actual Latin word physiognomi being used. It is also tied to Pliny's Natural History, which we know has both a brief mention of physiognomy, by idea and examples if not by name, and references to ideas like the evil eye that can be said to indicate physiognomic consciousness.

Despite such exceptions, the overall trend until the thirteenth century was one of waning physgionomic consciousness in Latin Christendom. The reversal of this tendency, which would be a direct and conscious tackling of the theoretical and ethical dimensions of physiognomy, would wait until the twelfth-century translation movement and the corresponding thirteenth-century rise of scholasticism and the university milieu.

\section{The Thirteenth-Century Resurgence of Physiognomy}

Thirteenth-century Latin Christendom was intellectually a time of great absorption, synthesis, and then originality largely because of the twelfth-century translation movements in Toledo and Sicily. Given the almost infinitesimally small traces of even physiognomic consciousness in Europe in the centuries before, it is logical to assume that thirteenth-century works of, or that included, physiognomy would be influenced by Polemon, Pseudo Aristotle, or some of their Arabic inheritors and

${ }^{190}$ Policratus, 263. Tradunt etiam Physiognomi, eos qui habent oculos maculosos, ad nequitiam proniores. 
translators. Indeed, this is demonstrably true in the case of the likes of Michael Scotus and Albertus Magnus.

However, another thirteenth-century thinker who included physiognomy in his writings gives us no real evidence to support such an assumption. Vincent of Beauvais (1190-1264) wrote the encyclopedic Speculum Maius, which includes three books, the first of which is the Speculum Naturale. This first portion was available by around 1245 . Within it, chapter 28 is dedicated to physiognomy, or as it is titled in the Venetian edition of 1591, "De phisonomia membrorum humani corporis" ("The physiognomy of the members of the human body"). ${ }^{191}$

Nevertheless, it is not likely that this chapter reflects the newly introduced Latin translations of physiognomic works. This likelihood is because instead of relying on Polemon, Vincent relies on Pliny's quotation of Trogus's physiognomic readings. Indeed the chapter, which is prefaced with "Plinius li. II" by Vincent, is almost a word for word quote of Pliny. When Pliny's chapter 114 is compared line by line to the 1591 edition of Vincent's Speculum, it quickly becomes clear that with only the exceptions of a few corruptions of the text and a few examples of physiognomic readings that Vincent omitted, the texts are identical. ${ }^{192}$

${ }^{191}$ Speculi Maioris Vincentii Burgundi Praesulis Beluacensis Ordinis Praedictatorum, Theologi ac Doctris Eximii. Venice, 1591.

192 The omitted portions include nec universa haec, ut arbitror, sed singula observat, frivola, ut reor, et volgo tame narrata, and the last few lines of Pliny which are candida pars extenda notam inpudentiae habet; qui indentidem operiri solent, inconstantiae. oricularum magnitudno loquacitatis et stultitae nota est. See the chart and the end of the chapter. 
This direct excerpt of the entire passage means that Vincent not only offers nothing original in his addressing of the topic of physiognomy, but that, at least on this subject, he marks himself as one of the last of the tradition of physiognomic consciousness, that Latin awareness of the practice that does not add much new or include much theory if any at all.

Instead it is scholars such as Michael Scotus (1175-1232) who first encounter and write about physiognomy in response to the new translations. In fact, Michael's Liber physiognomae is sometimes considered "the reestablishment, the rebirth of the discipline." ${ }^{193}$ His physiognomy has also been called the first true treatise on physigonomy to be written in the medieval west. ${ }^{194}$ This is appropriate because Scotus forms a bridge between the twelfth-century translation movements and the thirteenthcentury, university-based Scholastic syntheses. After beginning work in Toledo around 1217, by 1228 he was at the Sicilian court of Frederick II Hohenstaufen (1194-1250). There he worked on his Liber Introductorius maior in astrologiam, which he dedicated to Frederick. The work was divided into three books, the last of which was the Liber physiognomiae.

The Liber physiognomiae is itself divided into 102 chapters, although, despite its title, scholars have long noted that it is only in chapter 23 that the work begins to address

${ }^{193}$ Jole Agrimi, Ingeniosa Scientia Nature: Studi sulla fisiognomica medievale (Firenze: Sismel Edizioni del Galluzzo, 2002), 5.

${ }^{194}$ Danielle Jacquart, "La Physiognomie à l’Époque de Frédéric II: Le Traité de Michel Scot," in M. R. McVaugh and Véronique Pasche, eds., Le scienze alla corte di Federico II (Turnhout: Brepols, 1994), 19. 
physiognomy directly. ${ }^{195}$ The previous chapters cover, instead, the process of generation. ${ }^{196}$ Lynn Thorndike attributed this to "a conscious or unconscious imitation" of the Secretum Secretorum's topics and organization. ${ }^{197}$ This interpretation is supported by the fact that Philip of Tripoli's translation of the Pseudo-Aristotelian Secrets was circulating at Frederick II's court, and a few direct quotations of it are found in Scotus's work. ${ }^{198}$ Nevertheless, the relationship between Secret of Secrets and Scotus's Liber Physiognomiae has been largely classified as one of sense or spirit more than literal quotation or copying, including a sense that physiognomy is indeed "secret" knowledge that should not be casually shared. ${ }^{199}$ Indeed, a common alternative title for his Physiognomie is De secretis naturae.

However, these first 23 chapters are not as divorced from the later physiognomic ones as the scholarly discussion may imply. This connection is largely because they do include information on using outward, physical signs to gain knowledge. These signs include those of the various humoral complexions, those denoting pregnancy, those denoting the sex of the unborn child, and those that reveal whether or not the child is healthy.

${ }^{195}$ Michael Scotus's Liber physiognomiae information is based on the Liber phisionomie magistri michaelis Scoti. Basileae: Michael Wenssler, c. 1485.

${ }^{196}$ Lynn Thorndike. A History of Magic and Experimental Science: During the First Thirteenth Centuries of Our Era, vol. II (New York: Columbia, 1923), 328-329.

197 Thorndike, A History of Magic and Experimental Science, 329.

198 Jacquart, “La Physiognomie à l’Époque de Frédéric II,” 20.

199 Jacquart, “La Physiognomie à 1'Époque de Frédéric II,” 20. 
Scotus's Physiognomie does include comparative information on animals in two chapters. However, despite the work's title and general subject, these two chapters are a comparative exploration of the generation of men and animals, instead of the physiognomic readings of men based upon their likenesses to animals. This way of addressing animals makes these two chapters more taxonomic than physiognomically interpretive. $^{200}$

A more important addition by Scotus to his physiognomy is that of material from Rhazes's Ad Almansorem. This makes Scotus's work on physiognomy arguably the first in Latin to incorporate the medicalization of the practice that its Arabic authors and transmitters had introduced during the previous centuries. The influence of Rhazes is largely seen in Scotus's list of the instructions for determining the complexion of an individual and of the principal organs, offering a direct link between humoral medicine and physiognomy. ${ }^{201}$ In fact, chapters $24-43$ focus specifically on the signs of different complexions: hot, cold, humid, dry, temperate and healthy, distempered and ill, etc., as well as the complexions of the major organs.

A final addition is the offering of a definition of physiognomy. Scotus writes that "physiognomy is the ingenious natural science by which is known of the virtue and vice of any animal."202 This relatively simple explanation is more useful in explaining the practice's function than its theoretical underpinnings. Yet, it does offer insight into the

\footnotetext{
${ }^{200}$ Jacquart, “La Physiognomie à l'Époque de Frédéric II.” ${ }^{201}$ Jacquart, “La Physiognomie à 1'Époque de Frédéric II,” 22. 202 Translated from Jacquart, “La Physiognomie à l’Époque de Frédéric II,” 19.
} 
way that Scotus understood physiognomy, as a useful, though perhaps dangerously powerful, tool.

Nonetheless, the second half of Scotus's physiognomy is presented in straightforward chapters that are organized by body part, listing signs followed by interpretations. Most of these are standard physiognomic fodder, such as the eyes, hair, nose, hands, legs, and feet. Chapters for the less anatomical signs, such as those of the voice, laughter, breathing, and the gait are also present, though they are mixed with the anatomical ones. For instance, the chapters on the breath, the voice, and laughter are positioned between the chapters on the tongue and chin while the chapter on the gait follows those on the parts of the legs and feet.

The eyes, as in most physiognomic works, are given a very long chapter towards the start of the list (Chapter 63). However, Scotus does attribute an unusually extensive list of attributes to many of his signs. For instance, a man who has eyes that are low in the head, but not in a hollow or long face, is said to be a suspicious man, malicious, of great anger, corrupted habits, strong memory, as well as audacious, severe, easily deceptive, fierce, vicious, luxurious, haughty, envious, and seductive. ${ }^{203}$ The length of the work also allows Scotus to include some topics that are uncovered or less thoroughly covered elsewhere in physiognomy. For instance, chapter 74 deals with the beard, 96 with the instep of the foot, and 99 with the humped and the scrofulous.

${ }^{203}$ Michael Scotus, Liber Phisionomie (Michael Wenssler: Basil, 1485), 113. significant homenem suspiciosum maliciousu $(m)$ magne $(m)$ ire $(m)$ perversi moris valde memorem audacem crudelem facile mendacem minacem viciosu $(m)$ luxuriosum superbum invideu(m) et seductorem. 
As a whole, these characteristics of Scotus's work firmly establish physiognomy as a practice or secret or even a medicalized scientia worthy of, and even ideally confined to, the highest intellects of the day. It is noteworthy, however, that Scotus chose to place his physiognomy within a larger work of astrology, allowing him to simultaneously moor the subject to both divinatory or determinative practices and medicine. This ability seems to be a paradox only to modern ears and not medieval ones.

In summary, the physiognomy that Albertus inherited was one based largely upon the works of Polemon and works attributed to Aristotle. The most important aspects of these works were their lists of signs and interpretations, their use of likenesses to animals, and their geographic, or ethnographic, signs and interpretations. These works were then synthesized with medical works, or medicalized, by their inclusion in works of Islamic medicine. Finally, after being largely lost in the Latin west, these physiognomic works were recovered, and in some ways discovered, through the fruits of the translation movements of the twelfth and thirteenth centuries. 


\begin{tabular}{|c|c|}
\hline Vincent of Beauvais (1591) & Pliny's Natural History \\
\hline $\begin{array}{l}\text { Miror autem Aristotlens non modo } \\
\text { credidisse praefecta vitae esse aliqua ipsis, } \\
\text { verum etiam prodidisse. }\end{array}$ & $\begin{array}{l}\text { Miror equidem Aristotelem non modo } \\
\text { credidisse praescita vitae esse aliqua in } \\
\text { corporibus ipsis, verum etiam prodidisse. }\end{array}$ \\
\hline $\begin{array}{l}\text { Quae quamquam vana existimo, nec sine } \\
\text { contatione proferenda, ne in se quisque } \& \\
\text { auguria quaerat, attingam tamen quae } \\
\text { tantos vir in doctrina non spreuit. }\end{array}$ & $\begin{array}{l}\text { quae quamquam vana existimo nec sine } \\
\text { cunctatione proferenda, ne in se quisque ea } \\
\text { auguria anxie quaerat, attingam tamen, quia } \\
\text { vir in doctrinais non sprevit }\end{array}$ \\
\hline $\begin{array}{l}\text { Igitur vitae breuis signa ponit raros dentis, } \\
\text { praelongos digitos, plumbeum colorem, } \\
\text { plursq(ue) in manu insciffuras nec } \\
\text { perpetuas. }\end{array}$ & $\begin{array}{l}\text { igitur vitae brevis signa ponit raros dentes, } \\
\text { praelongos digitos, plumbeum colorem } \\
\text { pluresque in manu incisuras nec perpetuas. }\end{array}$ \\
\hline \multirow[t]{2}{*}{$\begin{array}{l}\text { Contra longae esse vitae incuruvos } \\
\text { humeris, \& in manu una duas insciffuras } \\
\text { longas habentes, \& plures quam. } 32 \text {. } \\
\text { dentes, auribus amplis. }\end{array}$} & $\begin{array}{l}\text { contra longae esse vitae incurvos umeris et } \\
\text { in manu unam aut duas incisuras longas } \\
\text { habentes et plures quam XXXII dentes, } \\
\text { auribus amplis. }\end{array}$ \\
\hline & $\begin{array}{l}\text { nec universa haec, ut arbitror, sed singula } \\
\text { observat, frivola, ut reor, et volgo tame } \\
\text { narrata. }\end{array}$ \\
\hline $\begin{array}{l}\text { Addidit quoque morum aspect(um) simili } \\
\text { modo apud nos Trogus, \& ipse auctor } \\
\text { seuerissimus, quos verbis eius subijciam: }\end{array}$ & $\begin{array}{l}\text { addidit morum quoque spectus smili modo } \\
\text { apud nos Trogus, et ipse auctor e } \\
\text { severissimis, quos verbis eius subiciam: }\end{array}$ \\
\hline $\begin{array}{l}\text { fons magna ubi est, segnum animam inesse } \\
\text { signat, quibus parva mobilem, quibus } \\
\text { iocanda, iracundum, velut hoc vestigio } \\
\text { tumoris apparent. }\end{array}$ & $\begin{array}{l}\text { Frons quibus est magna, segnem animum } \\
\text { subesse significat; quibus parva, mobilem; } \\
\text { quibus rotunda, iracundum, velut hoc } \\
\text { vestigio tumoris apparent. }\end{array}$ \\
\hline $\begin{array}{l}\text { Supercilia quibus porriguntur in rectum, } \\
\text { molles signat. }\end{array}$ & $\begin{array}{l}\text { supercilia quibus porriguntur in rectum, } \\
\text { molles significant }\end{array}$ \\
\hline Quibus iuxta natum flexa sunt, austeros. & quibus iuxta nasum flexa sunt, austeros \\
\hline Quibus iuxta tempora inflexa, derisores. & quibus iuxta tempora inflexa, desiores; \\
\hline $\begin{array}{l}\text { Quibus in totum dimissa maliuolos \& } \\
\text { invidos. }\end{array}$ & $\begin{array}{l}\text { quibus in totum dimissa, malivolos et } \\
\text { invidos. }\end{array}$ \\
\hline $\begin{array}{l}\text { Occuli quibus cumque, longi, maleficios } \\
\text { esse moribus indicant. }\end{array}$ & $\begin{array}{l}\text { occuli quibus utrimque sunt longi, } \\
\text { malificos moribus esse indicant; }\end{array}$ \\
\hline \multirow[t]{4}{*}{$\begin{array}{l}\text { Qui carnosos a naribus angulos habent, } \\
\text { malitiae nota praeventi. }\end{array}$} & $\begin{array}{l}\text { qui carnosos a naribus angulos habent, } \\
\text { malitiae notam praebent; }\end{array}$ \\
\hline & $\begin{array}{l}\text { candida pars extenda notam inpudentiae } \\
\text { habet; }\end{array}$ \\
\hline & $\begin{array}{l}\text { qui indentidem operiri solent, } \\
\text { inconstantiae. }\end{array}$ \\
\hline & $\begin{array}{l}\text { oricularum magnitudno loquacitatis et } \\
\text { stultitae nota est. }\end{array}$ \\
\hline
\end{tabular}

yellow $=$ small differences $\quad$ green $=$ words or phrases missing from the other 


\section{CHAPTER 3: Medicine and the Medicalization of Physiognomy}

One of the auxiliary sciences absolutely necessary for proper physiognomy, as it was understood in the Middle Ages, was medicine. Specifically needed were the subdisciplines of anatomy, physiology, and psychology. Although it is of importance to medieval physiognomy, psychology is less present than anatomy and physiology in $D e$ animalibus, and therefore also in Albertus's physiognomy, because it is covered elsewhere in his work. It is not surprising that a science that involves "reading" the human body in order to predicate something about the owner's nature would necessitate thorough knowledge of anatomy and physiology. This relationship between medical knowledge and physiognomic knowledge explains why Albertus's physiognomic work is located in books two and three of De animalibus, books that devote themselves equally to the anatomy and physiology of humans, specifically their members, because there must be a setting forth of a human's members in general. For the human is the most worthy of the animals and has, with respect to number and shape, more perfect members than any of the others. Further, that which is more imperfect can be known better from those that are perfect and well known. And the human's are better known to us than the others'. 204

\footnotetext{
${ }^{204}$ Albertus, De animalibus. Kitchell, 86. Stadler, 39. Consequenter autem in universali narranda sunt membra hominis, eo quod homo dignissimum est animalium et perfectiora membra liabet secundum nuinerum et figuram quam aliquod aliorum. Ex perfectis enim bene cognitis melius poterunt et imperfectiora cognosci: notiora etiam sunt nobis humana quam aliena.
} 
The immediate contextual question is why a high-ranking, thirteenth-century Dominican who was a recognized and celebrated authority in theology, the queen of the medieval sciences, would interest himself in medicine, much less physiognomy. In part the answer lies in the fact that medicine had entered the Middle Ages primarily as a liberal art. ${ }^{205}$ However, like most disciplines, early medieval medical knowledge was much impoverished when compared to its classical forebears, with little of the two greatest physicians, Hippocrates (460-370 BCE) and Galen (130-210), translated into Latin. Prior to the rise of the universities, what medical knowledge remained in Latin Europe was focused on cathedral centers such as Chartres, where students were required to read Hippocrates's Aphorisms. ${ }^{206}$ It has been estimated on the basis of only 150 extant medical manuscripts, that for the ninth and tenth centuries there may have been no more than a thousand in total for the whole of Europe. ${ }^{207}$ Nevertheless, enough was communicated that elemental and humoral theory was carried through in some form from the classical era through the Middle Ages.

The Aphorisms, for instance, while true to their name in their brevity, contain enough information on the meaning of symptoms, diet and other treatments for the ill, and the importance of seasons and temperature. For example, section one, number 15 tells us that

${ }^{205}$ Vern L. Bullough, Universities, Medicine and Science in the Medieval West, (Aldershot, England: Ashgate Variorum, 2004), 3-4.

${ }^{206}$ Bullough, Universities, Medicine and Science, 6.

${ }^{207}$ Nutton, in Martin Porter, Windows of the Soul: Physiognomy in European Culture 1470-1780 (Oxford: Clarendon Press, 2005), 71. 
in winter and spring the bowels are naturally the hottest, and the sleep most prolonged; at these seasons, then, the most sustenance is to be administered; for as the belly has then most innate heat, it stands in need of most food. The well-known facts with regard to young persons and the athletae prove this. ${ }^{208}$

While such aphorisms do not offer a truly Galenic perspective on the humors, the Hippocratic work would offer a medieval student compatible treatments and signs.

This paucity of sources was remedied beginning in the eleventh century as copies of medical works, both from Greek and Arabic originals, made their way to Europe and were translated into Latin. The arrival of Constantine the African (1017-1087) in Sicily was followed by his Pantegni, an abbreviated translation of the Kitāb al-maliki (The Royal Book) by Haly Abbas, known in Arabic as 'Alī ibn al-'Abbās al-Majusi (d. ca. 994). Constantine also translated the compendium composed by Haly Abbas of the medical works of Joannitius, the Latin name for Ḥunayn ibn Isḥāq al-'Ibādī (ca. 809-873), whose own work was based on Galen's Art of Medicine. This compendium became known as the Isagoge of Johannitius (Isagoge Ioannitii ad Tegni Galieni) and quickly became the standard Galenic text used in Europe, even after much better translations became available. ${ }^{209}$

The popularity of the Isagoge made it the core of the Articella, a collection of medical texts that became a standard and widespread university text. The Isagoge itself,

${ }^{208}$ Hippocrates, Aphorisms, trans. Francis Adams (University of Adelaide, 2005).

${ }^{209}$ Faith Wallis, ed. Medieval Medicine: A Reader, series ed. Paul Edward Dutton (University of Toronto Press, 2010), 139. 
as revealed in a 1536 edition, focuses on the recognition of signs of illnesses and their cures. ${ }^{210}$ In typical medieval fashion, it is arranged by body part into seven books, beginning with the head, with each illness given its own chapter. The first illnesses are those of the hair, such as losing it (de capillis cadentibus), and lice (pediculis). The cures given for each illness help to explain the enduring popularity, if not always efficacy, of the treatments offered. For instance, a treatment recommended for lice is a mixture of larkspur (Delphinium staphisagria), natron, and red arsenic trisulphide (auripigmentum, a medieval dye), which was to be combined with oil and vinegar (cum oleo et aceto tempera). ${ }^{211}$

The book on the illnesses of the head includes chapters on lethargy, sleeplessness, madness, epilepsy, and numbness of members. However, the illnesses of the face are given a separate grouping that constitutes the second book. An introduction to the second book notes that "we begin therefore from the eyes, which are the most worthy parts of the face. $" 212$ The illnesses of the worthy eyes are then followed by those of the ears, nostrils, lips, tongue, teeth, and mouth.

\footnotetext{
${ }^{210}$ Constantini Africani Post Hippocratem Et Galenvm, Qvorum, Graec[a]e linguae doctus, posthabendi opera (Basil: Petrus, 1536).

${ }^{211}$ Constantini Africani Post Hippocratem Et Galenvm, book I, chapter 9. Larkspur is not an unknown ingredient in the thirteenth century. Albertus notes that it can be used to treat falcons in De animalibus. Stadler, 1475. Cura autem huius est quod tria grana stafisagriae cum totidem granis piperis in mortario lapideo vel cupreo optime conterantur, et pulvis inde confectus cum aceto forti distemperetur et cum bombace in nares falconis et in palatum ipsius eiciatur, et postea cibetur carne pullina.

${ }^{212}$ Constantini Africani Post Hippocratem Et Galenvm, book II, introduction, 26. "Incipiamus ergo ab oculis, qui digniores partes sunt faciei."
} 
The remaining books continue to move their focus down the body, addressing maladies of the encountered body members. The third and fourth books first address illnesses of the respiratory system and heart before moving into the digestive system. Book V addresses organs such as the liver and kidneys, but it also offers a small divergence from the previous form by devoting entire chapters to different types of remedies. For instance, there are chapters on antidotes, tablets (trochiscis), decoctions and syrups (apozematibus et sirupis), and purgatives (catharticis). The sixth book addresses sexual and reproductive matters, such as gonorrhea, abscesses of the testicles and womb, and difficulty in childbirth. The last two chapters, dealing with sciatic nerve pain and gout, seem to be the only outliers from the common reproductive theme. The final book seems to be in some ways a catch-all for the illnesses that can either occur on almost any portion of the body, such as bleeding cuts (sanguine fluenti ex incisione), wounds (vulneribus in corpore), and bites, or affect the entire body or the skin. Examples of the latter include chapters on smallpox (uariolis) and fevers.

However, from the introduction to this early sixteenth-century edition of the Isagoge, it is clear that it is Constantine and his classical forebears, Galen and Hippocrates, who are to be celebrated and given credit for this medical knowledge. ${ }^{213}$ Despite the fact that the Arabic nature of the sources was suppressed, the translated works established a tradition of "Galenic" learning in Salerno by the beginning of the thirteenth century. ${ }^{214}$ In the twelfth century Spain experienced a parallel translation

\footnotetext{
${ }^{213}$ In fact, the entire 1536 volume is attributed to Constantine, including the other works on urine, the stomach, proper nutrition for the ill, melancholy, coitus, sickness of women, and surgery.

${ }^{214}$ Nutton, in Porter, Windows of the Soul, 73.
} 
movement. There, Gerard of Cremona (1114-87) translated Avicenna's Canon of Medicine, and many other works of medicine, both Galenic and Arabic were translated as well. $^{215}$

The availability of these new texts in the twelfth century led in part to what Faith Wallis has called medicine's "theoretical turn," although she applies it specifically to Salerno. $^{216}$ These texts worked in tandem with the rise of the university in Europe as medicine was gradually separated from its monastic home and practicing doctors (medici) gradually became more specialized and more regulated. After Constantine, Salerno quickly became known for its medical education, and other cities in Italy followed. For instance, Taddeo Alderotti (d.1295) was Bologna's first recorded professor of medicine in the thirteenth century. ${ }^{217}$

Although most famous for its theological studies in Paris, France was soon also host to medical learning in its universities. Montpellier, known for its learned physicians since at least 1137, evolved into a university and absorbed the "new" Galen texts as well as Avicenna's Canon in the middle of the thirteenth century, becoming in the process where medicine first assumed its position among the arts. ${ }^{218}$

Paris did not have the same long-standing reputation for physicians, but nevertheless had masters such as Adam of the Petit Point who is recorded by Alexander Nequam (1157-1217) as having taught physica in the mid-1170s, teaching medicine just

\footnotetext{
${ }^{215}$ Nutton, in Porter, Windows of the Soul, 73.

${ }^{216}$ Wallis, Medieval Medicine, 195.

${ }^{217}$ Wallis, Medieval Medicine, 197.

${ }^{218}$ Bullough, Universities, Medicine and Science, 15-17.
} 
before law and theology. ${ }^{219}$ He lists Joannitius's Isagoge, Hippocrates's Aphorisms and Prognosis, Galen's Tegni and Pantegni, Constantine's Viaticum and Theophilus's Book of Urines among the required list of texts to master, noting Constantine's role as translator. Much like Montpellier, Paris developed university medical studies in the thirteenth century. Vern Bullough put such teaching as early as 1213, basing his evidence on statutes giving faculty the right to grant licenses in physica, but notes the term medicine was not used until 1251, while faculty regulation for medicine first appears in statutes from $1270-74 .^{220}$ The 1270-74 curriculum looks quite similar to that of Adam of Petit Pont's, with Constantine's Viaticum, the Pantegni, Theophilus, and Galen (through the Articella) in common. ${ }^{221}$

Albertus would have encountered the flowering of both the Italian and the French medical university traditions, first in Padua, and later in Paris. While it is highly unlikely that Albertus had formal medical training, it is certain that theoretical aspects of medicine interested him greatly. ${ }^{222}$ While Albertus was not a physician, his De animalibus shows an absorption with physiology and anatomy, disciplines that were as much natural philosophy (physica) as they were medicine. Nancy Siraisi has noted that Albertus is an

219 Alexander Nequam, “Adam of the Petit Pont's Reading List in Physica," in Wallis, Medieval Medicine, 193-95. For more on Taddeo Alderotti, see Nancy Siraisi, Taddeo Alderotti And His Pupils: Two Generations Of Italian Medical Learning (Princeton University Press, 1981).

${ }^{220}$ Bullough, Universities, Medicine and Science, 33-34.

221 “The Curriculum of the Paris Medical Faculty in 1270-74," in Wallis, Medieval Medicine, 195-196.

${ }^{222}$ For Albertus's medical training, or lack thereof, see Nancy Siraisi, Medicine and the Italian Universities, 1250-1600 (Leiden: Brill, 2001). 
excellent example of a theologian who included discussions of these disciplines and, in doing so, made contributions to the debates in those fields. In part she attributes this to the scholastic nature of most university subjects: "the same scholastic apparatus of arguments, objections, and solutions; and many of the same citations of authorities often crop up in all three."223 Yet, in terms of medicine, Albertus was most likely self-taught, a part of his gradual acquisition of natural philosophy that began in Paris and continued for decades in Germany. ${ }^{224}$

De animalibus is also a portion of Albertus's commentary on Aristotle's libri naturales and helped to popularize the use of the Philosopher's anatomical and physiological works in university medical training. ${ }^{225}$ The learned reputation that allowed Albertus to influence medical curriculum is also reflected in his inclusion with the great medical minds, for instance on the frontispiece of a fifteenth-century medical manuscript by Giohanne Cademosto, now in the collection of the Bibliothèque Nationale, Paris. ${ }^{226}$ In this frontispiece, he is in the company of Asclepius, Hippocrates, Avicenna, Rhazes, Aristotle, Galen, Macer, Albertus Magnus, Dioscorides, Mésué (Yuhanna ibn Masawayh), and Serapion.

${ }^{223}$ Nancy Siraisi, Medieval and Early Renaissance Medicine (University of Chicago Press, 1990), 79.

${ }^{224}$ Nancy Siraisi, "The Medical Learning of Albertus," in Albertus Magnus and the Sciences: Commemorative Essays 1980, ed. James A. Weispheipl (Toronto: Pontifical Institute of Medieval Studies, 1980), 388.

${ }^{225}$ Nancy Siraisi, "The Medical Learning of Albertus," in Albertus Magnus and the Sciences: Commemorative Essays 1980, ed. James A. Weispheipl (Toronto: Pontifical Institute of Medieval Studies, 1980), 380.

${ }^{226}$ Nutton, in Porter, Windows of the Soul, 63. 
Despite these numerous connections between Albertus Magnus and medieval medicine, De animalibus reveals that he was in some ways quite separate from the emerging medical school tradition, in part because he was self-taught. This is seen in the authors that are missing in his citations. Despite almost constant mentions of Galen, including mentions of On Complexion, On Accident and Disease, On Sperm, and On the Care of the Members, the Tegni, Galen's more famous work, is absent. Additionally, scholars have found no instance by name of Johannitius and his Isogoge in any of Albertus's works. ${ }^{227}$ The lack of these specific works, however, does not mean that Albertus was not well-read, nor that De animalibus is not well-informed. In fact, the work abounds with references to medical authorities, both Greek-Hippocrates, Aristotle, Galen — and Arabic_-Rhazes, Haly Abbas, Avicenna, and Averroes. Because Albertus is commenting on and enlarging upon Aristotle's De animalibus and other libri natura separating individual cases of quotations or citations would be somewhere between impossible and quixotic. However, the other sources can be analyzed in some depth.

\section{Hippocrates in De Animalibus}

Hippocrates is mentioned by name seven times in De animalibus. Some of these references are in the overtly physiognomic sections. The most obvious is the story in which Hippocrates confirms Phylemon's physiognomic portrait of his nature, thereby giving medical credence to the practice. ${ }^{228}$ Hippocrates is again mentioned with

${ }^{227}$ Nancy Siraisi, "The Medical Learning of Albertus," in Albertus Magnus and the Sciences: Commemorative Essays 1980, ed. James A. Weispheipl (Toronto: Pontifical Institute of Medieval Studies, 1980), 389.

${ }^{228}$ Albertus, De animalibus. Kitchell, 93. 
"Phylemon" at the end of a chapter on the physiognomy of the eyes, this time to order to point out that Phylemon was his contemporary. ${ }^{229}$ The first time that Hippocrates's medical knowledge is cited is for the use of honey-water as a test for cramping, from his test confirming pregnancy in Aphorisms. ${ }^{230}$ This is representative of the majority of Albertus's use of Hippocrates because the remaining instances all revolve around issues of fertility and child-bearing. In a discussion on sperm, Albertus notes that according to Hippocrates it descends from the head through spermatic veins. ${ }^{231}$ Indeed, in $O n$ Generation 1 Hippocrates notes of these vessels that "they lead from the entire body to this part, and pass out of the brain to the loin," and later "for the greatest part of the seed flows from the head past the ears into the spinal marrow." ${ }^{, 232}$ Clearly this is not a direct quotation, but the basic anatomic knowledge is in place. It is knowledge that Albertus relies upon again when in a chapter on pregnancy through copulation and sterility, when he writes of testing the "upper passages" through which sperm flows. ${ }^{233}$

${ }^{229}$ Albertus, De animalibus. Kitchell, 108. Stadler, 60. Phylemon autem antiquissimus physyonomus qui contemporaneus fuit Ypocratis Cohy.

${ }^{230}$ Albertus, De animalibus. Kitchell, 283. Kitchell notes this is from Aphorisms 5.41. Stadler, 221. Et ideo dicit Ypocras, quod mulier quae concepit, patitur torciones si bibat mellicratum quia opprimitur a matrice intestinum per quod deberet exire ventositas.

${ }^{231}$ Albertus, De animalibus. Kitchell, 423. Stadler, 348. Ypocras autem Cohus sperma omne dixit descendere a capite per duas venas quas spermaticas vocavit.

${ }^{232}$ Hippocrates, On Generation 1, trans. Paul Potter in Hippocrates, vol. X (Harvard University Press, 2012), 7 and 9-11.

${ }^{233}$ Albertus, De animalibus, 16, 2, VIII. Kitchell 1227. Stadler, 1135. Superiores autem vias tam in se quam in yiris per quas maior pars spermatis descendit, experimentantur per ea quae multum sunt subtilis substantiae colorantia multum sicut est crocus; et talia ponunt super oculos, et si color penetrans coloraverit salivam, sciunt sperma a cerebro liberum habere descensum. 
Albertus also notes that Hippocrates supports the necessity of sperm remaining in the womb for conception to occur, saying,

Hippocrates agrees with this, telling of a woman who did not wish to become pregnant from intercourse and, seeing that her womb had taken in sperm, leaped mighty leaps to make it flow out. She would have done this only if the womb were very strong in retention of it. From this it is clear that the womb desires to retain sperm. ${ }^{234}$

Hippocrates does indeed tell this story, as found in On the Nature of the Child:

A female relative of mine once owned a very valuable singing girl who had relations with men, but who was not to become pregnant lest she lose her value. The singing girl had heard what women say to one another, that when a woman is about to conceive, the seed does not run out of her, but remains inside. She understood what she heard and always paid attention, and when she one time noticed that the seed did not run out of her, she told her mistress, and the case came to me. When I heard [what had happened], I told her to spring up and down so as to kick her heels against her buttocks, and when she had sprung for the seventh time, the seed ran out on to the ground with a noise, and the girl on seeing it gazed at it and was amazed."235

${ }^{234}$ Albertus, De animalibus, 9, 2, I. Kitchell, 804-05. Stadler, 706. Et huic consentit Ypocras, qui retulit de muliere quae ex coitu impraegnari nolebat, et videns matricem recepisse sperma, dedit saltus magnos ut efflueret, quod et fecisset, nisi matrix fortissirna fuisset in retinendo ipsum: ex quo patet quod matrix desiderat retinere sperma.

${ }^{235}$ Hippocrates, On the Nature of the Child 2, trans. Paul Potter in Hippocrates, vol. X (Harvard University Press, 2012), 35-37. 
It is clear that Albertus's retelling is considerably abbreviated and missing some of the elements of the original, but again the basic idea, this time of the fertile, conceiving womb retaining sperm, is the same and the story close enough to see the Hippocratic root. That the story is in De animalibus but not in original form is not surprising because it was a well-known and widespread story in antiquity, judging from the large number of sources in which it appeared. ${ }^{236}$

Albertus again calls upon Hippocrates when discussing the equality of male and female complexions, though this is likely taken from Avicenna. ${ }^{237}$ However, in the same chapter he has an uncited use of Hippocrates. After dismissing a number of tests for fertility, he writes:

What seems truer and most plausible is what others have said, namely, that if a fumigant is made for the woman out of aromatic herbs and that if the fumes are directed toward her womb with a funnel, and if the woman senses the odor of the aromatic herbs in her mouth and nose, it is a reasonably certain sign that she is not blocked up by bad humors. ${ }^{238}$

\footnotetext{
${ }^{236}$ Paul Potter, Introduction to On the Nature of the Child, in Hippocrates, vol. X (Harvard University Press, 2012), 28.

${ }^{237}$ De animalibus, 10, 2, I, 845 in Kitchell. Stadler, 749. Non est praetermitteudum, quod Ypocras dicit, quod videlicet non est vir oninino superior muliere in complexione membrorum principalium et in complexione sua prima corporis et in complexione spermatis sui sani, nisi accidat ex accidentalibus aliquibus variantibus complexionem.

${ }^{238}$ De animalibus, 10, 2, I, 845 in Kitchell. Stadler, 749. Verius autem est et vicinius probabilitati, quod dixerunt alii, quod videlicet fiat suffumigatio mulieri ex aromaticis et uirigatur fumus ad matricem cum traiectorio, et si mulier senserit odorem aromaticorum in ore et naso, signum satis certum est, quod ipsa non est opilata malis humoribus.
} 
This does, as has been pointed out in the English edition of De animalibus, match Aphorisms 5.59, which reads

If a woman do not conceive, and wish to ascertain whether she can conceive, having wrapped her up in blankets, fumigate below, and if it appear that the scent passes through the body to the nostrils and mouth, know that of herself she is not unfruitful. ${ }^{239}$

However, the details between these two are different enough to not match exactly, despite matching somewhat better than Hippocrates's other fertility tests involving smelling the breath, which involve suppositories of garlic or bitter almond that can be smelled on the breath afterwards if the woman is fertile. ${ }^{240}$

The final mention of Hippocrates in De animalibus is still on the general subject of procreation, but in this case it is Albertus quoting Constantine quoting Hippocrates on the womb closing up upon conception and on a prominent left testicle producing male children. ${ }^{241}$

\section{Galen in De Animalibus}

Albertus's use of Galen as source is unsurprisingly extensive. Galen's accounts of disputed or controversial positions or questions would, after all, have to be addressed

${ }^{239}$ Hippocrates, Aphorisms, trans. Francis Adams (McGraw-Hill, 2015), 24.

${ }^{240}$ Hippocrates, On the Nature of Women and On Barrenness, Trans. Paul Potter in Hippocrates, vol. X (Harvard University Press, 2012), 303, 339.

${ }^{241}$ Albertus, De animalibus. Kitchell, 1442. Stadler, 1351. Ut enim in Pantegni ait Constantinus, id quod recipit matrix, undique ita brancat atque claudit, ne sicut Ypocras dicit, punctum acus intrare possit: et sic ut frequenter orificium interius manet clausum, quousque forma infantis compleatur. 
by any thinker of repute. One of the medical questions that still remained in the thirteenth century was how to define the proper roles of the heart and liver in the body. At the theoretical center of the issue is which member "receives but does not bestow" powers and which members "transfer their powers to other members." 242 Galen is uniquely supportive of the prominent role of the liver over the heart. Albertus notes "Galen says that the heart receives its nourishment and nutritive power from the liver."243 The importance of Galen's views on the liver are addressed further by Albertus in a "digression" chapter on the things that Galen objects to in Aristotle. By "things," Albertus means the origins of the veins. Albertus prefaces the chapter by writing, "The view of Galen is contrary in many cases to the things that have been said here." ${ }^{244}$ The unique position of Galen to which Albertus is referring is that the veins arise from the liver. Albertus notes that Galen's proof lies in the fact that there are many capillaries (capillares) in the liver but "not throughout the entire heart." ${ }^{245}$ Albertus does not just identify Galen's opposition to the opinions of others, but also makes a positive judgment of Galen's work: “Galen, then, points out these and similar visible clues and uses reason

${ }^{242}$ Albertus, De animalibus. Kitchell, 71. Stadler, 27. Ut sit membrum et suscipiens et dans virtutes, et sit aliquod suscipiens et non dans, et sit aliquod non suscipiens ab aliquo, quod sit intra corpus, sed dans omnibus.

${ }^{243}$ Albertus, De animalibus. Kitchell, 71. Stadler, 27. Et hoc est cor: licet Galienus dicat, quod suscipiat ab epate nutrimentum et virtutem nutritivam.

${ }^{244}$ Albertus, De animalibus. Kitchell, 358. Stadler, 289. Galieni quidem sententia in multis ad haec quae hic dicta sunt contrariatur.

${ }^{245}$ Albertus, De animalibus. Kitchell, 359. Stadler, 291. Venae autem capillares radices habent per totum epar et non per totum cor: et in gybositate epatis illae colliguntur in unam venam quae ventrem habens vocatur, quae nec ipsa tota ad cor extenditur, sed una pars eius. 
to state his objections." ${ }^{246}$ Galen is also cited for his original or unique stances in less disputed matters, such as the number of muscles in the hands. Albertus notes that it is only Galen who counts eleven. ${ }^{247}$

However, despite the fact that Albertus not only cites Galen often but also by name, Albertus's reliance on Avicenna's Canon for Galen's views is often left uncited in De animalibus. For instance, when Albertus writes that "Galen and Avicenna say that none of the bones except the teeth have sensation," he is almost definitely relying solely on the Canon rather than also having a copy of De usu partium at hand while writing. ${ }^{248}$ Similar Galen references are taken from many other portion of the Canon, including the subjects of the generation of the humors ${ }^{249}$ and Galen's disagreement with Hippocrates on the spermatic veins. ${ }^{250}$

\footnotetext{
${ }^{246}$ Albertus, De animalibus. Kitchell, 360. Stadler, 291. Haec igitur et similia visu ostendit et per rationem obicit Galienus.
}

${ }^{247}$ Albertus, De animalibus. Kitchell, 170. Stadler, 118. Illi vero qui sunt in acie superiori sub musculo qui expanditur super plantain manus, quem solum Galienus cognovit musculum, undecim sunt.

${ }^{248}$ Albertus, De animalibus. Kitchell, 119. Stadler, 71. Nullum autem ossium, ut dicunt Galienus et Avicenna, praeter dentes habet sensum. Kitchell cites Canon 1.1.5.5 as the likely passage Albertus used as his Galenic source. Niccolò di Deoprepio da Reggio produced the earliest known medieval translations of the Galenic texts into Latin in fourteenth-century court of Robert of Anjou, King of Naples (1275-1343). See Roberto Weiss, The Dawn of Humanism in Italy (London: H. K. Lewis, 1947), 19.

${ }^{249}$ Albertus, De animalibus. Kitchell, 404.

${ }^{250}$ Albertus, De animalibus. Kitchell, 423. Hippocrates holds that the sperm descends from the head in spermatic veins behind the ears, to the kidneys, then down to the penis. Galen does not necessarily agree. 


\section{Islamic Medical Sources and Constantine in De Animalibus}

The sources originally composed in Arabic are no less noteworthy than the Greek ones. These sources go far beyond Avicenna's Canon to include a long list of important and influential physicians. The Persian physician Mohammad-e Zakariā-ye Rāzi or Rhazes in Latin (d. 925) was best known in the Middle Ages for his encyclopedic Liber Continens. $^{251}$ Albertus names Rhazes specifically when he is talking about veins. Speaking of the artery that goes to the neck vertebrae, then the clavicle, and the shoulder blade Albertus continues, "After this it next comes to the hidden muscles of the humerus, according to Razi; then, associated with the vein of the armpit, it moves to the visible ones, doing so in such a way that it spreads among them while always remaining hidden until it reaches the elbow." 252 The other mentions of Rhazes by name come soon afterwards in discussions of the names Rhazes gives to certain veins. The "black vein" of the arm "is called the 'purple' [purpurata] by Razy" and as for the lesser saphenous vein in the leg, "Razy calls this one the scyatica." 253 While these mentions are somewhat brief and appear only in the first book of De animalibus, they are enough to persuade Siraisi that Albertus may have had a copy of Liber Continens while writing. ${ }^{254}$

${ }^{251}$ The Arabic title is The Virtuous Life (al-Hāwi $)$.

${ }^{252}$ Albertus, De animalibus. Kitchell, 191-92. Stadler, 137-38. Postea exinde venit in adiutorii musculos occultos, ut dicit Razi, et ad manifestos sociata cum vena asscellae, ita quod spargitur in eis semper manens occulta, donec pervenit ad cubitum.

${ }^{253}$ Albertus, De animalibus. Kitchell, 202-04. Stadler, 147. Et fit ex eis vena nigra, quae matrix viva quae purpurata dicitur, a Razy vocatur. Stadler, 149. Quae scyatica a Razy vocatur.

${ }^{254}$ Nancy Siraisi, "The Medical Learning of Albertus," in Albertus Magnus and the Sciences: Commemorative Essays 1980, ed. James A. Weispheipl (Toronto: Pontifical Institute of Medieval Studies, 1980), 389. 
Albertus's mentions of Rhazes and a second Persian physician, Haly Abbas, are intimately linked with Constantine the African and his translations and works. Constantine himself is mentioned frequently. He is among the great physiognomers according to Albertus, along with Aristotle, Avicenna, Phylemon, Loxus, and Palemon the orator. ${ }^{255} \mathrm{He}$ is also mentioned in a section on the bones of the head, where the crown bone "is also called the prow of the head by Constantine." ${ }^{256}$ Later Albertus notes that black bile, the melancholy humor is "as Constantine attests, the last of the natural humors. ${ }^{257}$ This has been traced to Constantine's De communibus medico cognitu necessariis locis, quales medicinae discipluli esse debeant, a treatise that corresponds with Haly Abbas, whom Albertus claims to detest for his "error."258

The next mention of Constantine shows that Albertus knew him as a follower of Galen's work. In a discussion of sperm he writes,

Those following the Stoics — such as Plato, Speussipus, and Apollo, and their follower Galen, along with his imitator, Constantinus-have said that the name of sperm belongs to each of [the sexes] in a single sense. They

\footnotetext{
${ }^{255}$ Albertus, De animalibus. Kitchell, 94. Stadler, 46. Ut autem melius sciantur ea, quae dicenda sunt, ponemus singulorum membrorum per se significationes, sequentes auctores magnos huius artis, Aristotelem videlicet et Avicennam, Constantinum et ipsum, quem commendat Aristoteles, Phylemonem, Loxum quoque et Palemonem declamatorem, qui de physonornya perfectius ceteris tradiderunt.

${ }^{256}$ Albertus, De animalibus. Kitchell, 116. Stadler, 68. A Constantino vero vocatur prora capitis.

${ }^{257}$ De animalibus, 3, 2, III. 401 in Kitchell. Stadler, 328. Est ultimus luiinorum naturalium, sicut testatur Constantinus.

${ }^{258}$ Kitchell and Resnick traced this to De communibus medico cognitu necessariis locis 1.25 .
} 
say this, asserting that the generative power belongs to male and female according to a single sense and that each of them has the organs necessary for generation, that the sperm of each of them actually possesses the formative power, and that this is located in the spirit contained within the viscosity of each sperm. But they do say that the power of active formation is stronger in the male sperm than in the female..$^{259}$

This point is one Albertus disagrees with, citing Aristotle's rule that "two causes never come together for the same effect of nature, causing in one and the same sense of the word 'cause'.". 260 Despite this point of disagreement, Albertus has listed Constantine here with a number of eminently respectable authorities.

The individual work of Constantine that Albertus most references is De coitu. One such reference is when Albertus writes, "As Constantine says, the pleasure is attached to intercourse so that it will be sought more and reproduction will continue."261

${ }^{259}$ Albertus, De animalibus. Kitchell, 419. Stadler, 344. Et quidam sequentes Stoyeos sicut Plato et Speusippus et Apollo et tandem sequens istos Galienus et huius imitator Constantinus dixerunt spermatis nomen utrique per rationem imam convenire, asserentes virtutem generativam secundum unam rationem convenire masculo et feminae et utrumque eorum organa generationi debita habere et spermata utriusqne virtutem formativam active habere, et hanc esse in spiritu qui intra viscositatem

utriusque spermatis continetur. Sed tamen cum hoc dicunt virtutem activae formationis esse fortiorem in spermate masculi quam in spermate feminae.

${ }^{260}$ Albertus, De animalibus. Kitchell, 419. Stadler, 345. Dicentes numquam ad unum et eamdem naturae effectum coneurrere duas causas per unam et eamdem intentionem causae causantes.

${ }^{261}$ Albertus, De animalibus. Kitchell, 814. Stadler, 716. Et ad hoc non intenditur delectatio secundum naturam, sed deleetatio, ut dicit Constantinus, appouitur coitui ut plus appetatur et sic continuetur generatio. 
De coitu is used multiple times in the final book of De animalibus in support of chapters on intercourse and generation. ${ }^{262}$

Albertus makes use of two of the most famous physicians who wrote in Arabic, but whose works were translated in Spain after Constantine's efforts in Sicily. Siraisi notes that the Andalusian scholar Ibn Rushd, or Averroes in Latin (1126-98), had his medical works translated too late for Albertus to use them. ${ }^{263}$ Nevertheless, Albertus was clearly aware of Averroes. In an introductory note before a discussion he says, Since it is our intention to pass on perfect doctrine in these matters, we will first set out the opinion of Aristotle on this matter, with a clear explanation. Second, we will point out what Galen says to the contrary, and third, we will introduce the solution of Avicenna in these matters. Fourth, however, we will point out all that Averroes says that is contrary to Avicenna and we will set forth his solution. Fifth, and finally, we will educe our opinion from all these, and we will prove it by use of reason and sold experiential knowledge that is completely trustworthy. ${ }^{264}$

\footnotetext{
${ }^{262}$ Albertus, De animalibus. Kitchell, 1440-1442.

${ }^{263}$ Nancy Siraisi, "The Medical Learning of Albertus," in Albertus Magnus and the Sciences: Commemorative Essays 1980, ed. James A. Weispheipl, (Toronto: Pontifical Institute of Medieval Studies, 1980), 396.

${ }^{264}$ Albertus, De animalibus. Kitchell, 351. Stadler, 283. Nos autem perfectarn de hiis intendentes tradere doctrinam primo ponemus de hoc sententiam Aristotelis cum explanatione manifesta et secundo obiciemus hoc quod contradicit Galienus, et tertio inducemus de hiis Avicennae solutionem. Quarto autem obiciemus omnia quae contra Avicennam obicit Averroys et ponemus solutionem suam. Quinto autem et ultimo ex hiis omnibus eliciemus opinionem nostram, et probabimus eam ratione et experimento certo quod non fallit.
} 
This not only places Averroes in exalted company, but it also appears to claim that Albertus had knowledge of his medical opinions. When Albertus arrives at Averroes's stance on the issue, he begins:

Avenroys does not entirely agree with this assessment [Galen's] in a certain book he wrote on the dispositions of the heart. His statements are as follows. He says that the origin of the food-power (that is nutrimental power) is in the heart, as is the origin of the spirit, veins, and nerves, so that the active heat [calor agens] and receptive blood [sanguis patiens] might be in one and the same place. ${ }^{265}$

Albertus does devote several chapters to his discussion of the various opinions on the veins and circulatory, with Averroes appearing again, along with Avicenna, as an example of those who have pointed out the errors Galen made when he did not allow for the heart being the home of "the principle of sensation and movement" by "distinguishing and determining sensations." ${ }^{266}$ Albertus couples the two physicians again in a later discussion on whether or not female sperm has the same formative power as the male. In support of his view that it cannot, Albertus writes

\footnotetext{
${ }^{265}$ Albertus, De animalibus. Kitchell, 365. Stadler, 295-96. Hanc autem determinationem Avenroys nequaquam in toto approbat in quodam libro suo quem de dispositionibus cordis composuit, et sua dicta sunt talia. Dicit enim, quod in corde est virtutis cibalis sive nutritivae et spiritus et venarum et nervorum origo, quatenus in uno et eodem esset calor agens et sanguis patiens.

${ }^{266}$ Albertus, De animalibus. Kitchell, 375. Stadler, 304. Propter quod aliud est principium sensus et aliud sensus virtutem determinans et distinguens et approprians. Principium autem sensus et motus est cor: approprians autem et distinguens et determinans sensus est organa determinatorum sensuum.
} 
Averroes and Avicenna follow this view, as do all those who have studied natural matters well and carefully. Some physicians, however, are ignorant of reason and philosophy. They offer the opinion of Galen even though it is not their business to offer an opinion of one or the other. ${ }^{267}$

These examples show that Albertus was aware of Averroes and thought highly of his medical knowledge. Indeed, Albertus's works disputing Averroes's metaphysical works mean that he was not elaborating on an otherwise spotless reputation, but instead picking out an area in which he saw the Andalusian as a genuine authority. ${ }^{268}$ Averroes's medical encyclopedia, the Colliget, was translated into Latin in 1285 by Bonacosa, five years after Albertus's death, a fact that lends strength to Siraisi's argument but does not explain how Albertus was acquainted with Averroes's medical opinions.

\section{The Theory of the Climes, Medicine, and Physiognomy}

Another theory intimately related to both medicine and physiognomy, the idea of climes, also made its way from the classical Mediterranean to the Islamic world and to Christian Europe. The idea of the world being divided into different climes, or klimata, is often associated with the Geography, or Geōgraphikē hyphēgēsis (Guide to Drawing a World Map), of Ptolemy (100-170). This work provided three distinct functions not available elsewhere: providing detailed topography of Europe, Africa, Asia, delineating

${ }^{267}$ Albertus, De animalibus. Kitchell, 420. Stadler, 345. Et hunc sequitur Avenroys et Avicenna et omnes qui in naturis bene et subtiliter studuerunt. Medici autem quidam ignari rationis et philosophiae. Galieni praeferunt sententiam, licet non ad eos pertineat de uno vel de alio proferre indicium.

${ }^{268}$ For instance Albertus's De unitate intellectus contra Avveroem. 
the role of astronomy in geography, and discussing how to make maps. ${ }^{269}$ However, for physiognomy and medicine, it is the climes which are of importance.

The climes are divisions of the world by unequal parallels, which are described by the maximum length of a day, meaning that within each clime the maximum length should not vary discernably. Although associated with Ptolemy, these climes are actually more attributable to earlier, now lost, geographical works, such as Ptolemy's cited predecessor, Marinos of Tyre (70-130) and the works of Aristotle, specifically his Meteorology, which cites a total of five zones: two frigid, two temperate, and one torrid. $^{270}$ However, it was the seven climes that became most common in later Greek divisions that medieval Europe inherited most strongly.

For our purposes, the climes are important because of how they are interpreted by thinkers in terms of which offers the most salubrious climate for man. Ptolemy himself noted that knowing the parallels was important because "from this last, one can also determine the lengths of nights and days, which stars reach the zenith or are always borne above or below the horizon, and all the things that we associate with the subject of habitations."271 Within physiognomy, this idea of associating climate with habitation, can be seen as a possible underlying theory that explains Polemon's predictive examples of his readings of men as he travelled and his frequent association of readings with entire groups of people. If climate influences not just health but the entire body and soul, it

${ }^{269}$ J. Lennart Berggren and Alexander Jones, Ptolemy's Geography: An Annotated Translation of the Theoretical Chapters (Princeton, NJ: Princeton University Press, 2000), 3 .

${ }^{270}$ Berggren and Jones, 10-13.

${ }^{271}$ Ptolemy, Geography, 58 in Berggren and Jones. 
could be an invaluable tool for providing a general physiognomic reading based upon the typical features of people from a certain area.

Ptolemy's Geography was also clearly influential in the late antique Mediterranean and beyond. For instance, Ammianus Marcellinus (330-400), and Cassiodorus (485-585), and Marcianus of Heraclea (fl. fourth century) read and sometimes translated the Geography. ${ }^{272}$ The Ptolemaic work was translated into Arabic as early as the ninth century, with Abu Ja'far al-Khārizim̄̄, known as Algoritmi (c. 780850), showing at least partial familiarity. ${ }^{273}$

The Islamic world widely adopted the Greek idea of seven climes (aqālìm), stretching from north of the equator to the northern artic, with what was beyond the seven uninhabitable for humans. ${ }^{274}$ These climes blended together with humoral medicine to explain much of Islamic ethnography, which was part of $a d a b$, or courtly Islamic culture. The belief that growth in utero was the "cooking" of the four humors meant that temperate climes, with the moderate, appropriate, and best amount of heat, provided the most "harmonious and balanced" temperaments. For the Islamic world, these optimal climes were the central zones encompassing Arab lands, Persia, parts of China, and most of the Mediterranean coast. ${ }^{275}$ This ethnography only reinforced negative stereotypes about the peoples of the north and south, specifically the Slavs, who "possess wide chests; they are brave and of savage dispositions . . . given to longevity because their

${ }^{272}$ Berggren and Jones, Ptolemy's Geography, 50.

${ }^{273}$ Berggren and Jones, Ptolemy's Geography, 52.

${ }^{274}$ Aziz Al-Azmeh, "Barbarians in Arab Eyes,” Past \& Present, No. 134 (Feb., 1992): 6.

${ }^{275}$ Aziz Al-Azmeh, "Barbarians in Arab Eyes," 6-7. 
digestion proceeds properly," and sub-Saharan Africans who lived in conditions "contrary to the lands of the north." Accordingly, "their colours are black, their waters salty and murky, their digestion poor ... their lives short." ${ }^{276}$

Such views found their way into the wider Islamic culture because they so handily allowed division of the world into the civilized and uncivilized, largely because climes were believed to have influence on the faculties and not just the appearances, to make a man either unable to think rationally or more likely to. ${ }^{277}$

By the twelfth and thirteenth centuries, the ideas of climes as appropriate or inappropriate habitats for humanity was demonstrably a part of Jewish European culture, discussed in the works of Jews living and writing for Jews in Iberia and southern France, such as Abraham bar Hiiyya of Barcelona (d.c. 1136). ${ }^{278}$

The theory of the climes had clearly reached Albertus Magnus in the thirteenth century, as is borne out by his De natura locorum. We know that this work of geography and cosmology was written before De animalibus because of the former's many mentions

${ }^{276}$ Ibn Butlan, "Risala jami'a li-funun nafia fi shira' al-raqiq" [A Comprehensive Discourse on Knowledge Useful for the Purchase of Slaves], in Nawadir al-makhtufat [Rare Manuscripts], ed. A. Harun, iv (Cairo, 1951), 372.

${ }^{277}$ J.T. Olsson, "The world in Arab eyes: A reassessment of the climes in medieval Islamic scholarship," Bulletin of SOAS, 77, 3 (2014): 489. Note that Olsson argues that, while widespread, the exact understanding and meaning of climes/humors was quite not so uniform as al-Azmeh would have us believe.

${ }^{278}$ See Resianne Fontaine, "Between Scorching Heat and Freezing Cold: Medieval Jewish Authors on the Inhabited and Uninhabited Parts of the Earth," Arabic Sciences and Philosophy, 10 (2000): 101-137. 
by name in the latter. ${ }^{279}$ De natura locorum is divided into three books and more than twenty chapters. The first book deals with the definition of "place" (locus), largely based on an Aristotelian argument of everything having a natural inclination to one place, but taking it beyond the elements' desire for rectilinear motion in order to apply it to plants, animals, and man. Albertus tells us,

There is evidence also in all bodies which are outside the place of their birth for a long time, since they are removed from the source of their preservation [the place of their generation] and their existence and we see this not only in men and other animals but even in plants which very often are planted in different places, and likewise stones are weakened in their own power when the are outside the place of their origins. ${ }^{280}$

This defining of terms is accompanied by a discussion of the idea of climes. Albertus follows his usual method of carefully noting the various points of view of those authorities he deems most important. In this case, he does so by noting that Plato, Pythagoras, and Homer divide the world into five zones, but that he agrees with those like Ptolemy and Avicenna. ${ }^{281}$ This yields two important points. First, that the area

${ }^{279}$ In the Stadler edition of De animalibus, De natura locorum is mentioned eight times: twice in Book III (on the influence of environment on hair and complexion), three times in Book XII, and one each in books XIII, XX, and XXIII.

${ }^{280}$ Albertus, De natura locorum, translation by Sister Jean Paul Tilmann OP, using both the Borgnet edition and the manuscript in the Vienna National Library (which is possibly an autograph) in her dissertation An Appraisal of the Geographical Works of Albertus Magnus and His Contributions to Geographical Thought (Department of Geography, University of Michigan, Ann Arbor: 1971), 27.

${ }^{281}$ Albertus, De natura locorum, 50-54. 
between the Tropic of Cancer and Equator is habitable, as is seen in men from parts of Ethiopia and India. ${ }^{282}$ Second, that there are seven habitable climes in the northern hemisphere, the more accepted version of the theory. Albertus divides the climes by latitude, with the following parameters:

\begin{tabular}{|l|l|l|}
\hline Clime & Latitude (in degrees) & $\begin{array}{l}\text { Length of the Longest Day } \\
\text { (in hours) }\end{array}$ \\
\hline First & $0-16$ & $12-13$ \\
\hline Second & $16-24$ & $13-131 / 2$ \\
\hline Third & $24-30$ & $131 / 2-14$ \\
\hline Fourth & $30-36$ & $14-141 / 2$ \\
\hline Fifth & $36-411 / 3$ & $141 / 2-15$ \\
\hline Sixth & $411 / 3-451 / 3$ & $15-151 / 2$ \\
\hline Seventh & $451 / 3-48$ & $151 / 2-16$ \\
\hline
\end{tabular}

However, Albertus argues in Book I, chapter 11 that it is not the fourth clime, but the sixth or even the seventh, that is the best place for man to live. Men grow strongest here, he argues, because the clime is the most balanced, being truly temperate with both mild winters and mild summers, unlike the fourth clime, where summer heat is excessive but the winters are not cold. ${ }^{283}$ It is not surprising that Albertus would want to find his own clime the best or that he categorizes the men from it as "very handsome of body, and of noble and fair stature, and they are beautiful in color, while the men of the fourth clime are small and dark." 284

Other aspects of geography are linked to health in the first book. For instance, he mentions that valleys are some of the worst places for human habitation. This is because

\footnotetext{
${ }^{282}$ Albertus, De natura locorum, 54.

${ }^{283}$ Albertus, De natura locorum, 77.

${ }^{284}$ Albertus, De natura locorum, 77.
} 
"it will always be full of gas from the earth through which it will infect and bloat bodies." 285 The opposite, for Albertus, are the healthiily elevated, but not mountainous, regions. These are "not too cold and not too dry" and the "air [in them] is frequently pure, since the cold represses the gases and the vapors which make the air impure."286

However, it is the second book of De natura locorum that most clearly links the theory of the climes with physiognomy and medicine, particularly humoral theory. The first two chapters deal with the typical humoral requirements for generation (heat and moisture) and the variation of mixtures by clime. Then, the third chapter begins a long description of the ways in which the climes determine the characteristics of the different peoples.

The first people discussed are the Ethiopians (Aethiopes), whom he uses as his example of the blackness caused by extreme heat and dryness in the second clime, which is closest to the Tropic of Cancer. Albertus believes the second clime is the hottest because of intense reflected heat from the sun. This heat and dryness influence their bodies from conception:

[the] first seed of generation is hot, and so is the womb of women hot and dry, and the semen which is conceived is burned by the very strong heat, and their bodies grow dark on account of the scorching of the body; for it gives off a fine moisture and it burns the earthly mass which remains, and generates blackness. ${ }^{287}$

\footnotetext{
${ }^{285}$ Albertus, De natura locorum, 88.

${ }^{286}$ Albertus, De natura locorum, 89.

${ }^{287}$ Albertus, De natura locorum, 101. Borgnet's Latin edition reads “quorum primum semen generationis calidum est, et matrix mulierem calida et sicca, et decoquit semen
} 
It is not just "blackness" that Albertus holds as the accidental results of the intense heat of the second clime. For him, it also "on account of heat" that we see the whiteness of teeth, the redness of tongues, gums, and throats, which are like "glowing coals" (carbones accesnsi), and thicker lips in this clime. ${ }^{288}$ The same heat that leaves two humors dominating, red and black bile, also provides negative and a few positive characteristics. The positives are that their dryness leaves them "light and agile," they do not have enough moisture to corrupt and leave them liable to fevers, and their heat leaves their bodies pliable, allowing for easy childbirth. ${ }^{289}$ The negatives are that because of dryness they have timid hearts, women do not conceive easily, and their evaporating moisture takes their spirit with it, aging them quickly and leaving a short lifespan of thirty years. ${ }^{290}$ The influences of the hottest clime on the mind provide another negative influence, making Ethiopians "frivolous." However, those in the first clime display a "keenness of spirit," such as, according to his example, the mathematicians of India. ${ }^{291}$ This predictive relationship between humoral theory, climes, and the kinds of people that they produce is continued in Albertus's next example, the Goths, Dacians and Slavs (Gothi et Daci). These peoples, the first two from the west and Slavs from the east, are offered as the converse to the Ethiopians. Their cold clime constricts their bodies and

conceptum decoctione fortissima, et nigrescunt corpora eorum propter corporis adustionem: educit enim calidum ipsorum humidum subtile," 562.

${ }^{288}$ Albertus, De natura locorum, 101.

${ }^{289}$ Albertus, De natura locorum, 101-102.

${ }^{290}$ Albertus, De natura locorum, 101-102.

${ }^{291}$ Albertus, De natura locorum, 102. 
holds moisture, producing white, fleshy, and phlegmatic bodies. ${ }^{292}$ The constriction of the flesh causes firmness of body that gives their women difficulties in childbirth. The constriction from their cold clime also means that the women "are rarely cleansed by menstrual flow, and frequently they bleed from the nose."293

Unsurprisingly, the Germans are a more moderate example. The cold constricts their bodies, but only enough to keep the various spirits and humors in, allowing them to conceive easily and maintain heat in their bodies, in both their blood and spirits. ${ }^{294}$ Germans in general fear fevers because they have enough moisture to risk corruption, but they do not fear bleeding wounds, having enough blood to not worry about losing some. The physical characteristics are thick, straight hair. Worth mentioning is Albertus assertion that

their humor of thick and bodily spirit does not respond to the motion and receptivity of mental activity. Therefore, they are dull-witted and stupid. They have not been exposed to the exercise of study. But when they are moved to study they persevere longer and they are much better by far after mental exercise. The proof of this is that the people of Milan always study law, liberal studies, and the arts, about which the Dacians and the Slavs care little. $^{295}$

${ }^{292}$ Albertus, De natura locorum, 102.

293 Albertus, De natura locorum, 102. Borgnet's Latin reads "raro emundantur a sanguine menstruo, et frequenter sanguinem emittunt de naribus," 563.

${ }^{294}$ Albertus, De natura locorum, 103.

295 Albertus, De natura locorum,104. Borgnet's Latin reads “Operationes autem eorum animales non vigent propter spissitudinem corporum eorum: est enim humor in eis piger, 
It is slightly peculiar that he singles out his own people as dull-witted and stupid, but not terribly surprising that he sees much to praise in the Germans when they do devote themselves to law and other studies.

Albertus sums up the ideal nature of those from the fourth and fifth climes but noting that their hearts, unlike the wolfish ones of the far north and light-hearted people of the south, allows them to "easily cultivate justice, keep their word, embrace peace, and love the society of men." ${ }^{296}$ To support this claim, he relies on Vitruvius's claim that the Romans lasted so long because their middle was between northerners and southerners. ${ }^{297}$

Such views on the influence of place on men are by no means unusual. Albertus's ideas are consistent with the likes of Vincent of Beauvais, Roger Bacon, Thomas Aquinas, and Bartholomew of England. ${ }^{298}$ However, this chapter of De natura locorum does provide an explicit connection between the nature of man and place, in terms of both his observable physical body and the nature of his soul that complements the ideas that physiognomy offers.

While the third chapter of Book II contains the most detailed ethnographic results of climate on the human body, the following chapter further underscores the connection between climate and the humoral temperament of the human body. Here, however,

et spiritus non obedit motui et receptioni formarum animalium. Sunt igitur tales hebetes et stolodi: nec hoc fit ex studii exercitio, sed quando moventur, multum durant et efficiuntur multo meliores post exercitium. Huius autem signum est, quod communitas populi Mediolanensis semper studet circa leges et studia liberalia et artes, de quibus non multum curat pupulus Dacus et Sclavorum," 564.

${ }^{296}$ Albertus, De natura locorum, 104.

${ }^{297}$ Albertus, De natura locorum, 104.

${ }^{298}$ For more, see Tilmann, 165. 
Albertus is not focusing on the longitudinally divided climes, but on location as defined by heat, cold, dryness, moistness, and a few other factors. These are also, for Albertus, predictors of the kinds of men who live there. For instance, if an area is rocky, level, cold, and dry, the men are strong with bony joints and are skilled in war. Meanwhile, if the area is moist and cold, the people will have beautiful faces, be fleshier, and tire more quickly, which in turn makes them less good at waging war. ${ }^{299}$

Mountains are also a large predictor of health or the lack of it. In general, those who live on them will have goiters because of their phlegmatic natures. However, it is the exposure of a place that is the most important, in other words, whether there is a single direction from which the area is not protected, and if so, which direction. The desirable exposure is an eastern one, because the sun at sunrise will "bring a pure breeze over them" and purify their air. ${ }^{300}$ Those with western exposures, on the other hand, "live wretchedly," while those in the south "live poorly." Those locations with northern exposures, while not as ideal as a western exposure, do produce muscular men who generate sons. $^{301}$

The final point worth mentioning from Book II is that Albertus does make a few connections to the animal world. For instance, he tells us that the influence on the color of man by the clime also has a similar influence on animals, resulting in the fact that northern animals tend to be as white as the men.

\footnotetext{
${ }^{299}$ Albertus, De natura locorum, 106.

${ }^{300}$ Albertus, De natura locorum, 107.

${ }^{301}$ Albertus, De natura locorum, 107.
} 
Overall, then, Albertus's De natura locorum provides a strong foundation for the physiognomy in his slightly later De animalibus. However, as we will see, he does not address the geographical category of physiognomy in De animalibus, perhaps, at least in part, because he had previously addressed the predictive nature of climate on man's nature in his discussion of geography and climes. 


\section{CHAPTER 4: \\ Theories of the Soul and Their Roles in Medieval Physiognomy}

In antiquity, physiognomy was a science based on medicine and anatomy but blended with metaphysical practices, particularly prophecy. While this emphasis met with a deep societal acceptance of prophecy in the Islamic world, it was less comfortably absorbed by the western Christian thinkers who first encountered physiognomy after treatises on it began to be translated into Latin in the twelfth century. While the medicine and anatomy involved in the science were of immediate interest to Europeans, the Christian iteration of physiognomy depends more heavily on theological and psychological conceptions of the soul than it does on a societal acceptance of prophecy at the highest intellectual levels.

If physiognomy is a science that allows a practitioner to predicate something about a person's soul and nature through examination of the face and body, then it requires an understanding of the soul that allows for a body-soul connection. Further, this connection must be one in which the soul has determined at least some of the physical features or in which the soul and the physical features have been determined by some third force in a consistent enough manner to render readable connections. Further complicating the issue is the question of the mutability of the soul. Must the soul be changeable for physiognomy to be possible? These requirements and questions make classical and medieval theories of the soul of the utmost importance when considering the ramifications of the introduction of physiognomy texts, through translation, commentary, and new works, into thirteenth-century Europe. 
By the time Albertus Magnus wrote De animalibus, somewhere around 1250, the dominant theories of the soul were Aristotle's, Avicenna's, Averroes's, and those of the Christian tradition. It was these theories with which Albertus had to wrestle as he commented and elaborated on Aristotle's works on animals, the most important and largest section of which deals with man's anatomy, physiology, and physiognomy. One might think that Plato (c. 427-348 BCE) should be included, but, though Plato's name was often cited in the Middle Ages, and his Timaeus was well known, his ideas had been enveloped by the Neo-Platonists and early Christian theologians and philosophers and he was, therefore, a less direct influence.

Additionally, because Albertus was writing De animalibus as part of an ambitious goal of commenting eventually on the entire Aristotelian corpus, it is clear that one of the biggest influences on his theory of the soul would be Aristotle. His access to the nearly complete Aristotelian corpus, through existing and new Latin translations from the Greek and a flood of new translations from Arabic, meant that Albertus also had at hand the commentaries on Aristotle by Averroes, specifically the Long Commentary on the De anima that was translated into Latin around $1230 .{ }^{302}$ Albertus had access to much of the metaphysical and physical work of Avicenna as well, including his translator Gundissalinus's twelfth-century De anima, which presents the ideas of Avicenna's Book of Healing (Kitab al-Sifā'). ${ }^{303}$ However, the first part of Albertus's career was spent as a Dominican theologian working at the still-young University of Paris in the 1240s, which

${ }^{302}$ Herbert A Davidson, Alfarabi, Avicenna, and Averroes on Intellect: Their Cosmologies, Theories of the Active Intellect, and Theories of Human Intellect (Oxford University Press, 1992), 300.

${ }^{303}$ Davidson, Alfarabi, Avicenna, and Averroes on Intellect, 211-214. 
rewarded Albertus with an excellent command of the Christian theories of the soul as well. Therefore, Albertus's theory of the soul had been formed by his familiarity with the work of men such as Augustine and Peter Lombard (1100-60), as well as many other Christian thinkers. The recent translations of Aristotle and Arabic sources, however, were something that Albertus had incorporated into his work in general and his theory of the soul in particular by the time he began composing De animalibus.

This set of sources means that Albertus's theory of the soul, like the majority of his work, required a careful harmonizing of Christian and early-Christianized classical theories with Islamic and newly acquired and not-yet-synthesized Greek theories. Luckily for Albertus, he excelled at harmonizing and weighing different authorities against one another. He was able to allow an authority to dominate one portion of a discussion while completely abandoning the same authority in favor of better work in another area. Yet Albertus also had the knack for creating something new from his syntheses.

\section{Greek and the Muslim Thinkers and Theories}

The foundational work that Albertus and all of his contemporary thinkers had to deal with when discussing the soul was Aristotle's De anima. Aristotle himself, living in the fourth century BCE, was not immune from needing to address the previously held conceptions of the soul. He devotes a great deal of the three books of De anima to refuting such ideas as that the soul is something that is moved in a circle, or that it is 
defined as something that moves itself. ${ }^{304}$ Aristotle notes, "This belief arises from their never seeing anything originating movement which is not first itself moved."305 This would give the definition of the soul as something that moves itself great explanatory power for the origin of movement. However, Aristotle continues, this cannot be so because this would make the movement essential to the soul rather than incidental (essence rather than accident). Further, Aristotle notes, "if the soul is moved, the most probable view is that what moves it is sensible things."306 He also dismisses the theory that the soul is a ratio or harmony, even though it "has rendered public account of itself in the court of popular discussion." 307 Supporters, writes Aristotle, argue that "harmony is a blend or composition of contraries, and the body is compounded out of contraries." Yet, Aristotle points out, "the absurdity becomes most apparent when we try to attribute the active and passive affections of the soul to a harmony - it is difficult to harmonize them." "308 This argument against the soul being a harmony is related to the argument that Aristotle makes in contradiction to the soul being made up of the four elements (earth, air, water, and fire), a theory that is problematic because it makes the soul a mixture. ${ }^{309}$

${ }^{304}$ Aristotle, De anima, J.A. Smith, trans. in The Complete Works of Aristotle, vol. I, ed. Jonathan Barnes (Princeton University Press, 1984), 413.

${ }^{305}$ Aristotle, De anima, 404. Aristotle attributes this to his predecessors in general, but shortly afterwards names Anaxagoras and Democritus as having similar ideas of the soul as the moving cause.

${ }^{306}$ Aristotle, De anima, 406.

${ }^{307}$ Aristotle, De anima, 407.

${ }^{308}$ Aristotle, De anima, 408. Aristotle makes similar arguments against Empedocles's assertion that the soul is a sort of ratio.

${ }^{309}$ Aristotle, De anima, Book II, Part 4. 
The reasoning behind the idea that the soul is a mixture of the elements is based upon the work of thinkers like Empedocles (494-44 BCE) who believe that like recognizes like. In other words, man's soul must have fire in it in order for it to recognize fire in the world, water to recognize water, etc. But if Aristotle were to concede that an elemental soul could be used to perceive the elements, then, he asks, "by what means will it know or perceive the composite whole, e.g. what god, man, flesh, bone (or any other compound) is?"310 These negations leave Aristotle with the basic conception of the soul he offers on his first page, that it is "in some sense the principle of animal life."

In the rest of his De anima Aristotle explores perception and cognition. These sections include relatively lengthy discussions of all the senses and how knowledge is gained, as well as the ontology of the soul and how it relates to the body. To prepare for these discussions he first asks a set of questions about the soul:

Is it 'a this-somewhat', a substance, or is it a quale or a quantum, or some other of the remaining kinds of predicates which we have distinguished? Further, does the soul belong to the class of potential existents, or is it not rather an actuality? Our answer to this question is of the greatest importance.

We must consider also whether the soul is divisible or is without parts, and whether it is everywhere homogeneous or not; and if not homogeneous, whether its various forms are different specifically or generically. $^{312}$

\footnotetext{
${ }^{310}$ Aristotle, De anima, 409.

${ }^{311}$ Aristotle, De anima, 641.

${ }^{312}$ Aristotle, De anima, 641-642.
} 
Some of these questions are definitely answered. For instance, to the question of whether the soul is potential or actual he firmly responds, "The soul is an actuality of the first kind of a natural body having life potentially in it." ${ }^{313}$ However, one of the greatest attributes of Aristotle's De anima is its ability to both draw in and frustrate thinkers with its ambiguity in a number of his discussions stemming from these questions. The philosopher spends page after page on the faculties of the soul, discussing the "nutritive soul" that is present in all living things, including plants, the "sensitive soul" that is present in all animals, and the "thinking soul" that is present in humans. Yet, at the same time he argues that soul cannot be divisible because, though the human soul has three capacities, it is only one soul. Furthermore, the soul perfects the living body, so it cannot consist of parts. Therefore the divisible, multi-parted thing could not be the soul, but instead the soul must be the connector, what unites all the disparate parts of a human. Thus, it is impossible for the soul to be multi-parted and, at the same time, fulfill all of the properties that Aristotle attributes to it. Yet, how the different faculties of the soul combine together into one homogenous soul and how this soul can be different in different kinds of living things are left largely unanswered.

The connection between the body and the soul is addressed similarly. Aristotle has much to say but, again, does not reach a definitive answer, at least not definitive enough to prevent millennia of discussion about exactly what he meant or intended. Much of what he says about the body and soul is contained in his discussion of "affections of the soul," which are "all affections of the complex of body and soul" with "no case in which the soul can be acted upon without involving the body; e.g. anger,

${ }^{313}$ Aristotle, De anima, 656. 
courage, appetite, and sensation generally."314 His explanation for these affections is that they are like straightness, something that cannot exist without a physical object like a bronze spear flying through the air. Thus, "it seems that all the affections of soul involve a body — passion, gentleness, fear, pity, courage, joy, loving, and hating; in all these there is a concurrent affection of the body." 315 In short, they are "enmattered accounts."

For the soul specifically, this connection means that while Aristotle does not ultimately define exactly how the soul and body are connected, he has made it clear that the soul must be present in a body, if it is to be alive, that it is one thing, and that its affections are intimately connected to the body. These affections leave open the possibility that physiognomy is a science that does not contradict the tenets of known classical Greek sciences, with implications for medicine, anatomy, and physiology, as well as the emotions.

In many ways Aristotle's descriptions of sensation, or more precisely how humans use their senses to perceive, provide the most important clue to the soul and to the ways in which physiognomy could be explained rationally. Of the senses, vision is the most important. First, Aristotle departed from Plato and the Neo-Platonists in allowing the soul to be receptive to the information provided by the senses. More specifically, he was an intromissionist whereas Plato was an extramissionist. In other words, while Plato describes eyes that emit fire "in a stream smooth and dense" in order

${ }^{314}$ Aristotle, De anima, 642.

315 Aristotle, De anima, 642. 
to pick up visual information, ${ }^{316}$ Aristotle has the eyes play a passive rather than active role. In order for physiognomy to work, this Aristotelian passivity of at least one of the soul's faculties is of utmost importance. Plato's extramissionist theory of vision does not allow for the physical influence of the body on the soul, and, even more emphatically, if Plotinus's strict hierarchy allows nothing inferior to affect anything superior, then the body would have no chance of affecting the soul or causing any illnesses thereof. ${ }^{317}$ The soul is superior to the body in Plotinus's estimation.

Conversely, Plotinus (204-270) and Late Antique thinkers in general created a model of the faculties of the soul and the body that worked quite well with the tenets of physiognomy. This complimentary tendency was the period's thinkers' preference for grounding the perceptual and cognitive process "in the body, which provides a material substrate of sorts. ${ }^{\prime 18}$ In other words, while their denial that the lower parts of man can affect the upper parts would be an impediment to physiognomy, the connections that perception and cogitation provide through the body to the soul would be beneficial.

However, because Albertus did not receive his Aristotle or Late Antique philosophers directly from the Greek, his reading of the De anima was heavily influenced by Arabic sources, Avicenna foremost among them. Abū 'Alī al-Husayn ibn 'Abd Allāh ibn Sīnā, known as Avicenna in Latin, was a Persian jurist and theologian, as well as

\footnotetext{
${ }^{316}$ Plato, Timaeus, in The Collected Dialogues of Plato, eds. Edith Hamilton and Huntington Cairns, Bollingen Series vol. 71 (Princeton University Press, 1961), 1173.

${ }^{317}$ Plato does allow or the for the soul to be changed through perception, however, which make it "confused and dizzy, as if drunk." See Phaedo (79b7-15) and David Bostock, Plato's Phaedo (Oxford: Clarendon Press, 1986), 118-120.

${ }^{318}$ Smith, Sight to Light, 143.
} 
philosopher and physician, making his work as important to theology as to medicine. ${ }^{319}$ Avicenna's own treatise which deals with the soul, the Kitab al-Sifä', was an attempt to preserve the incorporeality of the soul without the problematic Neoplatonic assertion that it pre-existed its joining with the body. Avicenna's work on the soul was original, but it was nevertheless treated as a commentary on Aristotle's De anima when introduced to the central Middle Ages via the translation movement. ${ }^{320}$ One clear departure from Aristotle lies in Avicenna's claim that the soul can be defined in two ways: as a spiritual immortal substance and as the body's "perfection." 321 This distinction was an immensely important tool for medieval Christians because it allowed them to bypass the problem raised by Aristotle's refusal to consider the soul as something that could exist outside the body, for if it were only the principle of animal life, how could it be separated from the physical animal? Avicenna's dual definition allowed for a possible solution. The word "perfection" is important in part because Avicenna does not use "form," freeing the soul from simply being the actualizing form of potential matter. God himself is "pure goodness and perfection" and man soul is the instrument through which he desires perfection and most nearly approximates it. ${ }^{322}$

${ }^{319}$ See Jon McGinnis, Avicenna (Oxford: Oxford University Press, 2010).

${ }^{320}$ Sander Wopke de Boer, The Science of the Soul: The Commentary Tradition on Aristotle's De Anima, c. 1260-c. 1360, in Ancient and Medieval Philosophy Series (Leuven: Leuven University Press, 2013), 17-20.

${ }^{321}$ Wopke de Boer, The Science of the Soul, 22-23.

${ }^{322}$ For Avicenna's description of God (The Necessary Existant) see tab al-Shifa', Metaphysics II, ed. Anawati, Ibrahim Madkour, and Sa'id Zayed (Cairo: al-hay'a al'amma lil-kitab, 1975), 355. This is derived from a logical exercise based on 
This solution was adopted by a veritable who's who of medieval thinkers, a list that begins with Dominicus Gundissalinus, who translated Avicenna's treatise on the soul into Latin, and includes John Blund (1175-1248), Peter of Spain (fl. thirteenth century), and Bonaventure (1221-74), as well as Albertus. ${ }^{323}$ Indeed, Gundissalinus is credited with the translation of Aristotle's De anima as well, further enmeshing the idea of "perfection" into the European explanations of the soul because it was introduced alongside the ancient ideas. ${ }^{324}$ Because the two were introduced together through translation into Europe, the ideas of Arabic works such as those by Avicenna were given greater credibility, sometimes even attributed to Greeks such as Aristotle. This idea of the soul as perfection is also an important solution for those such as Albertus who were trying to include physiognomy among the accepted sciences in the Middle Ages because "perfection" is most often used when medieval Christian thinkers discuss the relationship between the soul and the body. Yet most Christian theologians were less concerned with the connection between soul and body than they were with defining the soul as a hoc

modalities of necessity, contingency, and impossibility. See Nader El-Bizri, "Avicenna and Essentialism," The Review of Metaphysics, Vol. 54, No. 4 (Jun., 2001): 753-778.

${ }^{323}$ Sander Wopke de Boer, The Science of the Soul, 23-24. See also Dag Nikolaus Hasse, Avicenna's De anima in the Latin West: The Formation of a Peripatetic Philosophy of the Soul, 1160-1300 (London: Warburg Institute, 2000). See page 81 for the wide variety of medieval Latin thinkers who quoted from Avicenna's De anima and pages 60-69 for its influence on Albertus, who Hasse argues was the source of knowledge of Avicenna for late medieval thinkers, either directly through his De homine, or through Vincent of Beauvais's Speculum naturale, which depends upon Albertus's De homine.

${ }^{324}$ The other translation, done by Michael Scotus c. 1230 was accompanied by the Long Commentary by Averroes, making it also influenced by Arabic thinkers. See Smith, 242244. 
aliquid, or a thing in its own right, a substance. ${ }^{325}$ Defining the soul as an independent substance is of immense importance for theologians who need it to exist on its own after death in order to provide for the eternal life promised by Christianity. The soul, for Christianity, must be something separable from the body, something that can exist on its own without depending on a body for its ontological status.

This focus on the soul as a hoc aliquid in some ways provided the intellectual grounds for physiognomy because it left the relationship between body and mind still largely undefined. This lack of definition, while not in direct support of physiognomy, also offered no damaging information preventing a relationship that allowed for the body to be "read." However, for both Avicenna and Christian thinkers, the soul was indestructible and immortal, and therefore unchanging, a definition that would be problematic for some accounts of physiognomy.

In terms of cognition and the senses, Avicenna joined fellow Arabic-language thinkers such as al-Kindī, Ḥunayn, and al-Fārābī in following the basic stages set out in Late Antiquity: sensation to perception and conception to intellectual intuition, with all but the actual sensing occurring in the ventricles, or cells, of the brain. However, Avicenna, unlike the other Arabic thinkers, was a firm proponent of the intromissionist model of vision, pointing out the absurdity of a man being able exude enough visual material to reach the stars. ${ }^{326}$ In discussing cognition, Avicenna located what he called the five internal senses in the ventricles of the brain: common sense and retentive

${ }^{325}$ Sander Wopke de Boer, The Science of the Soul, 24-25.

${ }^{326}$ Jon McGinnis, Avicenna (Oxford: Oxford University Press, 2010), 109. See also, Smith, Sight to Light, 158-160. 
imagination in the front, compositive imagination and estimation in the middle, and memory in the back. Because this model was dominant in Europe from Albertus's active years in the thirteenth century until the early seventeenth century, it is a model worth noting, in part because it provides for both passive and active human functions during cognition. ${ }^{327}$ Yet the most salient point for physiognomy is that this model explains cognition as the abstraction of formal representations that have "been completely disengaged from [the] material entailments" of the physical objects they represent. ${ }^{328}$ In this way cognition through sense perception allows for a connection between the corporeal and the incorporeal through the intermediary of the senses.

No less important for Albertus as an authoritative source was Averroes. An Andalusi Islamic jurist, theologian, and philosopher, Averroes, like Avicenna, was as important for his theology and philosophy as his medical works. He produced commentaries on Aristotle that became so influential on European Christian thinkers after their translation into Latin that he was often simply known as the Commentator. ${ }^{329}$ While Albertus used Avicenna in general for "doctrinal enrichment" of his commentaries and elaborations of Aristotle, he used Averroes for "exegetical tools to explain the text." 330

${ }^{327}$ Smith, Sight to Light, 162, 166, 245.

${ }^{328}$ Smith, Sight to Light, 163.

${ }^{329}$ See Herbert A. Davidson, Alfarabi, Avicenna, and Averroes on Intellect: Their Cosmologies, Theories of the Active Intellect, and Theories of Human Intellect (Oxford: Oxford University Press, 1992).

${ }^{330}$ Amos Bertolacci, “Avicenna's and Averroes's Interpretations and Their Influence in Albertus Magnus," in Companion to the Latin Medieval Commentaries on Aristotle's Metaphysics, Companions to the Christian Tradition vol. 43 (Leiden: Brill, 2013): 109. 
However, Averroes's theory of the soul poses significant problems for Christian theology.

These problems originate with Aristotle's division of the intellect into possible, passive, and active. In book three, chapter 5 of his De Anima, Aristotle introduces the latter of these kinds of intellect, a type that is sometimes also called the agent intellect. ${ }^{331}$ However, Aristotle is unclear on whether this intellect, the one that potentially survives death, is one or different in each human being. ${ }^{332}$ Because of his contact with the Almohad theology, one that emphasizes unity, and because he strove to be true to Aristotle's original intent, Averroes answers emphatically that there is only one possible intellect and only one agent intellect.

All of Muslim theology emphasizes that God is the One, with no other gods or forms, in large part to point out the perceived errors of the Christian Trinity. The Almohad 'Aqìda, or Creed, includes just such a chapter, emphasizing "that [God] has no other with him in His power since if there were anyone sharing with Him, then He would be necessarily constrained by the limits of the created things from the necessity that the other independent being exist separately." ${ }^{, 33}$ However, the Alhomad dynasty, rulers of

${ }^{331}$ Aristotle, De Anima, 684.

${ }^{332}$ Recent arguments state that agent intellect is God (or the Prime Mover) moving us towards actualization. See Victor Caston, "Aristotle's Two Intellects: A Modest Proposal,” Phronesis, Vol. 44, No. 3 (Aug., 1999), 199-227.

333 "The Almohad Creed," trans. Madeleine Fletcher, in Medieval Iberia: Readings from Christian, Muslim, and Jewish Sources, ed. Olivia Remie Constable (Philadelphia: University of Pennsylvania Press, 1997), 196. In her introduction, Fletcher goes so far as to attribute the Creed to Averroes himself, in large part because of its dependency on the logic from Aristotle's Metaphysics, the familiarity with al-Ghazālī, and Averroes's position at court at the time the Creed was heavily reedited into the document known today (1183). For more on the deep level of interest in unity among the Almohads, see 
North Africa and Muslim Spain in Averroes's day, emphasized unity in new and more extreme ways. The empire's founder, Ibn Tūmart (ca. 1080-1130), was a jurist who tried to bring to northwestern Africa the "correct" practice of Islam after his hajj to Mecca. The name Almohad in Arabic is al-Muwahhidīn, meaning "those who declare tawhìd." 334 Tawhìd, translated as "unity" or "oneness," became the founding and enduring tenant of the ruling Almohads who patronized Averroes.

Averroes addresses the human intellect directly in seven treatises, namely, commentaries on Aristotle's De anima, his Epistle on the Possibility of Conjunction, two other short pieces that exist in medieval Hebrew and Latin, and a commentary on Alexander of Aphrodisias's De intellectu. ${ }^{335}$ Within these works, most notably in his Long Commentary and his Epitome of the De anima, he makes distinctions among the material (or possible) intellect, actualized intellect, and the agent or active intellect. Averroes's description of the human possible intellect changed over the course of his life, beginning with the belief that it is a disposition and ending with the opinion that it is a

Lucy K. Pick, Conflict and coexistence : archbishop Rodrigo and the Muslims and Jews of Medieval Spain (Ann Arbor : University of Michigan, 2004).

${ }^{334}$ Madeleine Fletcher, "The Almohad Tawhīd: Theology Which Relies on Logic," Numen, vol. 38, fasc. 1 (Jun., 1991), 110-127. Fletcher notes on page 113 that tawhid was so important that the chancery of the first Almohad caliph, Abd al-Mu'min issued a letter to each newly conquered city that ordered, "First, begin with the first principle of Islam and inculcate the people with the knowledge of the tawhid." These cities were already Muslim, and so this order had nothing to do with conversion, but instead everything to do with properly educating Muslims.

${ }^{335}$ Herbert A Davidson, Alfarabi, Avicenna, and Averroes on Intellect: Their Cosmologies, Theories of the Active Intellect, and Theories of Human Intellect (Oxford University Press, 1992), 263-264. 
non-material substance. ${ }^{336}$ What does not change is the central idea that man is born with the possibility to acquire knowledge, at which point the human intellect is potential, but must be actualized. Man's intellect is not capable of self-actualization, leaving Averroes to resort to the theory of divine illumination. This is the role of the active intellect, an intellect that is outside man and emits a light that illuminates images in the imaginative faculty and the material intellect, resulting in the actualization of the possible intellect. ${ }^{337}$ What makes Averroes problematic for Albertus is not this description of the potential, actual, and active intellects. Instead it is that Averroes states that the possible intellect is not many, but one. In other words, the same possible intellect is in all people.

Averroes's one possible intellect leaves humans with only one portion of the intellect not held in common, a corporeal individuated passive intellect, one that has no individual immortality. Although this theory accepts the soul as a hoc aliquid that can exist on its own after death, it eliminates the possibility of individual life after death because a human soul would lose individuality upon death, i.e. that which made it that particular human. This outcome was decidedly contrary to long-standing teachings of the church, for the individual immortality of the human soul had been well established by the church fathers. Albertus must, and does, therefore condemn Averroes on this heretical stance. Therefore, Averroes theory of the soul had little imprint on Albertus, or the way that he thought about its role in any science, including physiognomy.

\footnotetext{
${ }^{336}$ Davidson, Alfarabi, Avicenna, and Averroes on Intellect, 261. See also 268-270 for the development of Averroes's definition, from disposition in the Epitome, to a copy of the Epitome with a "correction" paragraph, to the Long Commentary that supports the assertion that the possible intellect is a non-material substance.

${ }^{337}$ Davidson, Alfarabi, Avicenna, and Averroes on Intellect, 316.
} 


\section{Thinkers and Theories of the Christian Tradition}

While the Arabic works entering Western Christendom via translation were of great importance to Albertus and in many ways were the basis of his scientific and philosophical works, understanding his conception of the soul also requires a deep understanding of the Christian tradition. By the mid-thirteenth century the Christian theological tradition was a rich one. For instance, the Church Fathers had wrestled with how to comment on the Bible, especially the books of the New Testament, within their Late Antique Mediterranean context. As a medieval theologian, Albertus was held by the authoritative convention that required him to build his arguments upon the words and idea of these Christian thinkers whose works predated his own. As a prominent Dominican, he was deeply familiar with the Church Fathers and other early sources as well as more recent Scholastic ones.

Among the Church Fathers, St. Augustine of Hippo stands out as a sort of primus inter pares. His views on the soul are therefore of lasting importance to the Christian tradition, though they are spread out among his many works. Key to his views on the topic are his favorable interpretations of the Platonic tradition that allow the soul to survive death. Augustine first had to Christianize Plato, but Plato's negative evaluation of the relationship between body and soul worked far better than Aristotle's theories. For Plato the body was the prison of the soul, meaning that a man should welcome death in order to escape the vices and temptations of the body. ${ }^{338}$ For Christians the soul's

\footnotetext{
${ }^{338}$ See Sebastian Gertz and Ramon Philipp, Death and Immortality in Late Neoplatonism: Studies on the Ancient Commentaries on Plato's Phaedo (Leiden: Brill, 2011), 172-174. for a discussion of the ethical valuations in the Phaedo of the soul's
} 
survival after death was not just a good, hopeful thing, but instead a necessary condition for their religion.

Indeed, for Augustine there were famously two subjects of legitimate inquiry: God and the soul. While these subjects are certainly well within the purview of philosophy, Augustine was not truly a philosopher but a theologian and perhaps an “occasional" philosopher. ${ }^{339}$ His work touches upon themes similar to those of Greek philosophy, but only because they fell within a tradition with which he was familiar. Augustine used these traditions as tool for his treatises as he made sense of the most important Christian religious issues of his day. His famous viewpoint of credo ut intelligam (believe in order to understand) meant that he began with belief as an assumption for his works, and Greek philosophy could only aid in clarifying portions of doctrine.

Because of his Christian faith, Augustine felt certain of the answers to some of Aristotle's questions about the soul but more doubtful of others. ${ }^{340}$ For example, he was certain the soul is a created substance. This certainty is important because its converse is that the soul is of the divine substance, i.e. while our souls are what make us in the image of God, they are not divine. Augustine also was certain of the soul's immateriality, that it did not have a corporeal body of its own, and that the soul's placement in a body was not

immortality, including the need for different post-corporeal outcomes for souls based upon how their embodied lives had been lived.

${ }^{339}$ The occasional description comes from Gerard O'Daly, Augustine's Philosophy of Mind (London: Duckworth, 1987), 5.

${ }^{340}$ O'Daly, 3,18 . He is unsure of whether or not souls are all created together at creation or individually as life comes into existence (tranducianism). He is also not definite on whether or not our souls are conceived from our parents' souls. 
a punishment for previous sins. Augustine, in short, firmly rejected the Platonic idea of reincarnation. $^{341}$

For Augustine the soul (anima) retains much of its basic ancient definition of being the presence of life in physical things. However, it is also triune, as Aristotle espoused, though this time with the justification of mirroring the image of God's Trinity. On the one hand, it is absolutely singular and undivided. On the other, it can be analyzed according to three capacities: memory, understanding, and will. The emphasis on will instead of intellect as the "superior faculty of the soul" gives Augustine's description a more active than passive character. ${ }^{342}$ Yet, perhaps most important for physiognomy is that Augustine was also certain that the soul is immortal but not immutable. A soul that can change, that can react and interact with its physical host, is much more likely to allow for physiognomic readings than one impervious to such interaction. Yet it is still individually immortal and therefore does not violate the Christian demand for an afterlife of damnation or salvation.

In De immortalite animae Augustine notes that there are two types of mutability for the soul, "for indeed the soul can be said to be changed in accordance with the body's affections, or in accordance with its own." ${ }^{, 34}$ The processes and sensations of life, such as illness, age, or pleasure can therefore change the soul, but so can bodily affections

\footnotetext{
${ }^{341}$ Plato's views on reincarnation are laid out at the end of the book X, the final book of The Republic in which he describes souls reentering the world through a system of lots (see 617d-e in The Republic, trans. Paul Shorey, in The Collected Dialogues of Plato). It is also put forth, though less clearly, in the Timaeus.

${ }^{342}$ Smith, Sight to Light, 153-154.

${ }^{343}$ Augustine, De immortalitate animae, 7.
} 
such as fear, anger, and even joy. For Augustine, the soul also "transmits form to the body" but without losing its own form. ${ }^{344}$

Augustine also deals with the relationship among original sin, the soul, and the body. Defining this relationship is important because from the Christian point of view the changing of the soul is seen almost entirely as a negative thing, one that is often blamed on man's sinful nature that results from the Fall. In De natura et origine animae, Augustine assumes that the soul preexists the body and is "polluted" at the "investiture of the flesh. ${ }^{, 345}$ At its origin the soul is entirely good, and indeed is often known as flatus or spiritus or even inspiratio instead of the term anima that can be applied to the soul of any living thing. For Augustine, men's souls come from the breath of God. This usage is Biblically drawn from both Old and New Testaments, from verses such as Genesis 2:7 and Revelation 11:11. In Revelation the word used is pneuma ( $\pi v \varepsilon \tilde{u} \mu \alpha)$ meaning wind or breathed air, but it also is the root of pneuma in Latin, ${ }^{346}$ where from the time of Galen it was used to denote psychic pneuma. This pneuma, distilled from the blood into the purest form possible, was the lightest material in the body, a substance that filled the cells of the brain and in which the mental processes took place, at least for those late antique and medieval thinkers who believed thinking to take place in a physical location at all. This association of the soul with pneuma has ramifications for both the connection between

\footnotetext{
${ }^{344}$ Augustine, De immortalitate animae, 24.

${ }^{345}$ Augustine, On the Soul and Its Origin, eds. Philip Schaff and Benjamin Breckinridge Warfield, trans. Robert Ernest Wallis and Peter Holmes (1887), Book I, ch. 6.

${ }^{346}$ O'Daly, Augustine's Philosophy of Mind, 8. O'Daly notes that the Latin pneuma was also based on the Greek pnoe from the Septuagint.
} 
body and soul and physiognomy. Pneuma is then one of the possible ways that the corporeal (humors) and incorporeal (soul) could be connected.

Overall, then, Augustine left a written legacy that allowed the Christian Latin thinkers who succeeded him to use much of the language and topics that occupied the philosophers before him, but not for the same reasons or purposes. He stressed the importance of the soul, but for theological reasons, with the most pressing issue being that of the state of the soul for the purposes of salvation. In this vein, when he was concerned with the "degradation" of the soul (through sin) or its "improvement" (through grace), he was analyzing the problem from the perspective of ethics rather than ontology. $^{347}$

If Augustine was primus inter pares among the Church Fathers, Peter Lombard served a similar function among theological thinkers of the central Middle Ages. One of the early influential Scholastic theologians at the cathedral school of Notre Dame and later a Bishop of Paris, he made a lasting mark as author of the Libri Quattuor Sententiarum, or the Sentences, as they are commonly known. The Sentences form a theological textbook, but not one meant just for university or cathedral school theologians. Instead it is "best read as if it were analogous to a legal casebook for the training of experts." 348 The first book deals with God through an exploration of the Trinity, the second with creation, the third with Christ, and the fourth with signs of Christ's grace. In reality all of the books deal heavily with signs and with Augustine,

${ }^{347}$ O'Daly, Augustine's Philosophy of Mind, 39.

348 Giulio Silano, "Introduction” to The Sentences, Book 2: On Creation (Toronto: Pontifical Institute of Medieval Studies, 2008), vii. 
because of his statement that all things are signs that point to God and that the Creator is the only true "thing" in the world. ${ }^{349}$ While Peter's logical organization and breadth was original, his reliance on a long chain of canonical Christian authors was not. As previously mentioned, Augustine is a large influence and is cited often, as are numerous other authors who lend Peter their authority.

Peter Lombard's treatment of the human soul comes primarily in Book II, which deals with the creation of the angels, the earth, and man, as well as original sin. Book II is divided into forty-four distinctions, which are further divided into chapters. It is in the midst of trying to come to grips with the creation of man and original sin that Peter delves most deeply into aspects of the soul, beginning with Distinction XVI and continuing through the last distinctions of the book.

In Distinction XVI Peter notes that it is in our souls that men are in the image of the Trinity but that this is an unequal likeness. ${ }^{350}$ As evidence of man's triune nature, man's soul has memory, intellect, and will. To strengthen this point he cites both Augustine and Bede (672-735) on the nature of this likeness of the human soul to God. The idea of the soul as the "breath of life" is repeated in echo of Augustine, although also with reference to Genesis 1:26. ${ }^{351}$ He also notes the different words used for God's creative action: inspiravit (breathed upon) for Augustine, but flavit (blew) or sufflavit

\footnotetext{
349 Philipp W. Rosemann, The Story of a Great Medieval Book: Peter Lombard's Sentences (Ontario, Canada: Broadview, 2007), 24.

${ }^{350}$ Peter Lombard, The Sentences, 71.

${ }^{351}$ Peter Lombard, The Sentences, 71.
} 
(inflated) for unnamed others. ${ }^{352}$ Also repeated are Augustine's certainties that the soul is neither corporeal nor formed from the substance of God. ${ }^{353}$ In all, Peter asserts that the human soul is like God in five ways: "its rationality, its possession of the Trinitarian analogy of memory, intellect, and will; its natural capacity to be innocent and just; its immortality, and its indivisibility.",354

Peter then spends a great deal of time differentiating between the nature of Adam's soul before the Fall and mankind's souls after the Fall. Before the Fall, Adam's soul "was both mortal and immortal, because, upon creation, it had the power to die and not to die." 355 It was also able not to sin because his soul had "the ability to discern between good and evil" 356 without any "study or any application over the passage of time, but [having] received it by God's gift from the beginning of his existence."357 Physiognomy would have been pointless in the context of the pre-lapsarian soul because there would be nothing for it to "read" on a physical body without sin. However, after the Fall, man had the "incentive to sin, namely concupiscence of the attraction to pleasure, which is called the law of the members, or the weakness of nature, or the tyrant

${ }^{352}$ For the Latin, see Sententiae in IV Libris Distinctae, $3^{\text {rd }}$ ed., vol 1, part 2 (Rome: Editiones Collegii S. Bonaventurae Ad Claras Aguas, 1971), 410.

${ }^{353}$ Peter Lombard, The Sentences, 71.

${ }^{354}$ Marcia L. Colish, Peter Lombard, vol. 1 (Leiden: E.J. Brill, 1994), 366. Though Colish sets out to provide a modern overview for the entirety of Peter Lombard's theology, there is relatively little analysis of the soul.

${ }^{355}$ Peter Lombard, The Sentences, 82.

${ }^{356}$ The Latin is habens discretionem boni et mali. Sententiae in IV Libris Distinctae Dist. XXIII, ch. 2, p. 448.

${ }^{357}$ Peter Lombard, The Sentences, 105. 
who is our members, or the law of the flesh." ${ }^{358}$ In terms of sources, this description is followed by citations of both Augustine and Ambrose (337-97) on the necessity of struggling to overcome this tyrant. ${ }^{359}$ Perhaps more importantly for my purposes, these sins would allow the body to affect the soul in ways that could be physically read.

Another question of the soul that concerns Peter greatly, if judged by words spent, is how souls, procreation, and original sin are interrelated. His answer is that although original sin is passed from the parents at conception, the soul is not transmitted from parent to child, so original sin is in the flesh but not the soul the moment before their joining. ${ }^{360}$ However, the soul does not remain clean because original sin taints the soul at the moment of joining and is afterwards found in the soul as well. This phenomenon is found "because it occurs in the soul through the corruption of the flesh."361 It is "from contact with such flesh, [that] the soul, as it is infused, derives the stain by which it is polluted and becomes guilty, that is, the vice of concupiscence, which is original sin."362 This point is not trivial. Indeed, it means that for Peter, the soul is not only capable of being influenced and changed by the body, but it is automatically and inevitably subject to such influence just by being joined with the post-lapsarian body.

${ }^{358}$ Peter Lombard, The Sentences, 149.

${ }^{359}$ Silano, The Sentences, 144. Silano notes that while Peter thought he was citing Ambrose, he was actually citing Ambrosiaster, an anonymous fourth-century commentator on St. Paul's letters who was conflated with Ambrose throughout the Middle Ages.

${ }^{360}$ Peter Lombard, The Sentences, 153-154.

${ }^{361}$ Peter Lombard, The Sentences, 154.

${ }^{362}$ Peter Lombard, The Sentences, 154. 
The body is certainly a theological problem for Peter. He quotes Augustine's De civitate Dei, noting that "the corruption of the body" is what "weighs down the soul.,"363 For Peter, this "weighing down" of the soul would certainly allow for the soul to be influenced by the body, while the need to tame the "tyrant" of concupiscence would necessitate the soul maintaining control over the body, leaving the Sentences and Peter Lombard's theology open to interpretations and applications of physiognomic theory. This theology also explains some of the tendencies within physiognomy, particularly that the majority of the signs are markers of negative traits. The predominance of these negative physiognomic readings is justified if they are built upon a foundation of corruption, meaning that to be read, a human must be corrupted by sin. Further, while all humans are tainted by original sin, and therefore should have something to be read by a physiognomer, the most striking examples will be those people who have not been able to use will to keep their souls properly in charge of their bodily desires.

The compatibility of the Sentences and physiognomy is not just convenient for Albertus's embrace of the science, but necessary. For the Sentences was not merely a textbook but an authority of such theological weight that men such as Bonaventure "sounded desperate" to defend themselves when accused of contradicting it. ${ }^{364}$ Peter Lombard's work was, in short, the "ultimate standard of orthodoxy. It represented the

${ }^{363}$ Peter Lombard, The Sentences, 161. Peter's full quotation of Augustine reads “non fuit corruptio corporis, quae aggravat animam, causa primi pecati, sed poena; nec caro corruptibilis animam peccatricem fecit, sed peccatrix anima carnem corruptibilem fecit." See Sententiae in IV Libris Distinctae, p. 515.

${ }^{364}$ Rosemann, The Story of a Great Medieval Book, 71. 
limits drawn around the scriptural core of the traditions, limits that all theological discourse had to respect under pain of heresy.”365

However Albertus was familiar with the works of many more Christian theologians than just St. Augustine and Peter Lombard. Many of these are mentioned by name in Albertus's works. One notable exception to this list of theologians is John Scotus Eriugena (c.800-c.877). Albertus's failure to cite him is notable because Eriugena's writings on the soul seem tailor-made for a thirteenth-century scholar trying to find a place for physiognomy within a synthesis of Christian and Aristotelian thought. Yet, the only mention of Eriugena by name in Albertus's works occurs in the latter's Summa theologiae, where Eriugena is briefly cited for his commentary on Dionysius's work on the Celestial Hierarchy. On the other hand, Albertus had good reason to ignore Eriugena's writing on the soul in his Periphyseon. Despite a brief period of popularity in the twelfth century among those working at Chartres and St. Victor, Eriguena's Periphyseon was condemned in 1210 for pantheism and again in 1225, when the Council of Paris condemned it for the same reasons, along with David of Dinant (1160-1217) and Amaury of Bène (d. c. 1207), two theologians at the newly chartered University of Paris. ${ }^{366}$ However, given the similar condemnations of Aristotle in the same period, and

${ }^{365}$ Rosemann, The Story of a Great Medieval Book, 71.

${ }^{366}$ Erwin Panofsky argues for Abbot Suger rediscovering Eriugena's work and his translations of Dionysius, but crediting Dionysius's work to St. Denis. He further argues that Suger's articulation of light metaphysics make him the originator of a movement that includes, in different branches, Robert Grosseteste, Roger Bacon, William of Auvergne, Henry of Ghent, Ulric of Strassburg, Marsilio Ficino, and Pico della Mirandola. See Erwin Panofsky, introduction to Abbot Suger: On the Abbey Church of St.-Denis and Its Art Treasures, trans. Erwin Panofsky (Princeton University Press, 1979). 
the clear lack of general adherence to those prohibitions, it is certainly plausible that some of the ideas of Eriugena still influenced Albertus, though not pantheism.

Eriugena's main work, the Periphyseon or Division of Nature, contains his anthropology in Book IV. The Periphyseon uses the dialectic trope of master and student to examine the contradictions of man's nature that make him exceptional among both corporeal and incorporeal beings. Eriugena defines the soul as part of a union with the body, making his definition of an animal, "the meeting place of soul and body in sensation." 367 That meeting is not fully explained. Instead the soul is "conjoined to the body in a mysterious manner [ineffabili modo]," though he admits that the senses play a mediating role. ${ }^{368}$ Perhaps the most direct definition of man comes when the "student" in the dialectic sums up a few of the "master's" main points, saying that "although man is a unity, he is in a manner of speaking composed out of a number of parts, for it is agreed that he is made up of a body, that is matter possessing a sensible form, and soul, which in turn is composed of sense, reason, intellect, and vital motion." ${ }^{, 369}$ This unity of man lends itself to physiognomy because if man's soul is part of a single whole, what affects the body can affect the soul, and vice versa.

${ }^{367}$ Eriugena, Periphyseon (The Division of Nature), trans. I.P. Sheldon-Williams, revised by John J. O'Meara (Montreal: Éditions Bellarmin, 1987), 392 (751C). The Latin is "est enim animal corporis et animae connexio." For Latin quotes of the Periphyseon see Iohannis Scotti seu Erivgenae: Periphyseon, Book 4, ed. Edward Jeauneau (Turnholt, 2000), 16 (751C 401-402).

${ }^{368}$ Eriugena, Periphyseon, 395. Latin Vnam uero eandemque rationabilem animam humano corpori ineffabili modo adiunctam hominem esse assero, 19 (754A 500-754B 501).

${ }^{369}$ Eriugena, Periphyseon, 436. Latin "Sed quoniam homo, dum sit unus, ueluti ex multis partibus compositus est-constat enim ex corpore, hoc est ex formata materia sensibili, et anima, hoc est sensu et ratione et intellectu et uitali motu," 66 (786C 1846-1849). 
Eriugena's understanding of how the bodily emotions affect the soul is also compatible with physiognomy. He deems "rage [furor] and covetousness [cupiditas] and all the inordinate appetites of the corporeal senses" to be "irrationals, which are resistant to reason." 370 These irrationals stem from the "infection" of our human natures by the animal portion. Irrationals are therefore "in continual revolt against the discipline of reason, and can rarely, if ever, be tamed thereby, but are ever seeking to attack savagely and devour the rational motions." ${ }^{371}$ Because physiognomy focuses more on negative emotions such as the rage and covetousness that Eriugena mentions, these emotions that cause the greatest changes, or accidents in the physical body, are some of the most easily "read."

However, it is really in Eriugena's copious discussion of and quotation from the Treatise on the Image by Gregory of Nyssa (c. 335-c.395) that he best displays the Periphyseon's compatibility with physiognomy. For instance, Eriugena quotes extensively from the fifteenth chapter of Gregory's work:

It was the purpose of our treatise to show that the mind [animum] is not retained in any given part of the body, but that it is in contact with all parts equally, and consequently operates the motion in accordance with the part of the nature which is subject to it. But there are times when the mind follows the inclinations of nature, as if it were the servant. For often bodily nature commands it, and imposes upon the mind the emotion of one

${ }^{370}$ Eriugena, Periphyseon, 393. Latin 17 (752A 406-409).

${ }^{371}$ Eriugena, Periphyseon, 393. Latin "praesertim cum semper rationabilibus disciplinis reluctari non desinant, et aut uix aut nunquam domari ab eis possint, mutusque rationabiles feroci impetu delaniare semper appetant,"17 (752B 411-414). 
who grieves and the desire of one who rejoices, so that it takes the initiative; exciting in the mind the hunger for food or the desire for some delightful thing. And the mind receiving these stimulants enters into a conference with the body for the purpose of gaining opportunities of satisfying them. This, however, is not with all, but only with those who find themselves more in the condition of captives, who force the reason to serve the desires of the bodily nature, and employ the mind servilely to flatter the lust which operates through the bodily senses. But in the more perfect it is not so. For the mind rules by reason, and is not passive, but chooses that which is useful: the mind marches before and nature follows after. $^{372}$

In many ways this passage epitomizes physiognomy. It posits a direct connection between mind and body that can be, and is, abused when the appetites of the body and the emotions associated with them lead the rational part of the soul away from its true purpose, which is to contemplate God.

Perhaps equally important is Eriugena's inclusion of Gregory's statement that the mind is not passive, that instead it actively and willfully rules the body. The converse, then, a mind and soul being passive and allowing the body to actively impress upon them and create accidents, is the opposite of the natural order. It is the unfortunate accidents that result from this corruption of the natural order, the body controlling the soul, that creates much of the material that physiognomy depends upon.

${ }^{372}$ Eriugena, Periphyseon, 442. After the first few lines, the Latin differs depending on which manuscript being sourced. See Édouard Juneau's Latin edition for versions 1-2 and 4-5, in which the section appears: 388-389 (792A-792B, various line numbers). 
Eriugena's quotations of Gregory persist for pages, including direct mentions of chapters 16,17 , and 27 . It is in his quotation of chapter 17 that Eriugena includes a key discussion of the corruptibility of the body. The body's corruptibility is evident in the standard changes that occur during one's lifetime. These changes are the growth and withering that occur as the child matures and then the adult ages, changes that Eriugena compares to changing garments, a rather superficial change. ${ }^{373}$ There is, for Eriugena, a deeper form. He states, "Throughout all these changes there is a form [forma] which abides and is itself unchangeable, never giving up those marks which were inscribed at one time on it from its very nature. ${ }^{, 374}$ In another addition offering hope to readers who might despair over the changes to their souls, the changes resulting "from some passion and which is an accident superimposed upon our form, is removed through the Word of God."375 This possibility of removal of physical accidents is important for physiognomy, in part because it means that if God can remove these traits, he must want, or at least allow, the trait and therefore its corresponding flaw to remain in the soul. This makes physiognomy much more palatable for Christians because it can be tied more firmly to origin sin which is present for Christians in every human at conception. Humans were

${ }^{373}$ Eriugena, Periphyseon, 452. "Mutatur enim per auctionem et diminutionem corpus." According to Jeaneau this passage is absent from version 3, but present and the same in the other four versions he used: 424-425, various lines.

${ }^{374}$ Eriugena, Periphyseon, 452. "Stat uero per omnem conuersionem instransumtabilis in se ipsa forma, insitis sibi semel ex natura signis non dessistens," 424-425, various lines.

${ }^{375}$ Eriugena, Periphyseon, 452. In versions one and two the Latin reads "subtrahitur autem per uerbum deum uidelicit ipsa quae ex passione est mutatio, quae formae superaccidit," 424 (801A 4359-4362). Version three is missing this portion while versions four and five are similar. 
not mutable before the Fall, points out Eriugena in his commentary on Gregory, and therefore changes to us can only be reversed by grace. ${ }^{376}$

While Albertus does not directly refer to these ideas of Eriugena and Gregory of Nyssa in his De animalibus or his De anima, he does mention Gregory almost eighty times in his Summa theologiae, with another handful of mentions in his commentaries on some of Aristotle's other works, such as Politics and Posterior Analytics. ${ }^{377}$ The Summa theologiae's use of Gregory as a Christian authority demonstrate an extremely high level of respect, not just in their sheer number, but in the way that they appear throughout the work and not in just one particular section or as an authority on one narrow issue.

Indeed, Albertus mentions Gregory in the third paragraph of his introduction. In between quotes from Canticles and Ezekiel, during a discussion of divine signs and seals, Albertus includes “Quod exponens Gregorius dicit: 'Signaculum est sigillum profundatum.,„378

This familiarity with Gregory could also help to explain the compatibility without direct citation of Eriugena.

Additionally, Eriugena was an important part of the lineage of medieval thinkers prior to Albertus. It is certainly plausible that a number of his ideas, including those

${ }^{376}$ Eriugena, Periphyseon, 453.

${ }^{377}$ For instance, in the Borgnet edition, Albertus mentions Gregory twice in the Posterior Analytics. The first, from Lib.I, tract.1, cap.5, p.16b, is "Et consentiunt in hoc Plato et Socrates multique alii, Boetius, et Augustinus, et etiam ut videtur, Gregorius Nyssenus, quod virtus sit nec assuescibile bonum, nec discibile, sed a Deo vel diis datum per conversionem animae ad seipsam." The second, from cap.6, p.18a, offers "Damascenus et Gregorius Nyssenus," as supporters of the theories of Anaxagoras.

${ }^{378}$ Albertus, Summa theologiae, ed. Borgnet, (1894-5), 2. 
concerning Gregory of Nyssa, passed along from scholar to scholar long enough to reach Albertus.

It is difficult to determine the line of transmission of theories of the soul in part because many of the men involved were Augustinian in the overall nature and goals of their work, leaving their theories of the soul to be extracted from theological treatises instead of laid out as the primary aim. Anselm of Canterbury (c.1033-1109), for example, like Augustine, has no one clear passage that sums up his conception of the relationship between body and soul. What he does state clearly is the importance of the soul, through reason, controlling the animal aspects of our natures, something that has already been seen in a number of other theories of the human soul.

For Anselm, the soul is the interior homo, or "inner man." It was, as he says in the Monologion, "created to love God endlessly, it is eternal. And because this is its purpose, to not do so is truly reprehensible. ${ }^{379}$ Anselm's De Concordia Praescientiae et Praedestinationis et Gratiae Dei cum Libero Arbitrio (The Harmony of the Foreknowledge, the Predestination, and the Grace of God with Free Choice) even stresses the importance of education and guidance in learning to actualize the soul's true purpose. He writes

similarly, without learning and endeavor human hearts freely germinate, so to speak, thoughts and volitions which are not conducive to salvation or which are even harmful thereto. But without their own kind of seed and without laborious cultivation human hearts do not at all conceive and

${ }^{379}$ Complete Philosophical and Theological Treatises of Anselm of Canturbury. Trans. Jasper Hopkins and Herbert Richardson (Minneapolis: Arthur J. Banning Press, 2000), 78. 
germinate those thoughts and volitions without which we do not make progress toward our soul's salvation. ${ }^{380}$

The Monologion also contains an important passage on the idea that something can be both active and passive. The example Anselm uses is a beating: "Giving a beating and getting a beating cannot occur separately: one and the same thing is signified by different words in accordance with its different aspects. Hence, beating (percussio) is said to consist of both giving a beating [percutiens] and getting a beating [percussus]." More important, this dual interpretation allows for different value judgments to be made for the active and passive portions of an action. For example the person who is being beaten may deserve the beating while the person delivering the beating may not be doing so for the right reasons, thus making the same event both just and unjust. ${ }^{381}$ This is important for physiognomy because it necessitates a two-way avenue of affect between body and soul in order for it to work logically. Ideally, of course, the soul will affect the body, but it can work the other way, though that is generally considered a kind of flaw or illness.

Thus, it seems that Anselm would be an important Augustinian source for Albertus. Indeed, Albertus cites him in his Sentences commentary and his Summa theologiae. But like Gregory of Nyssa, he is not mentioned in the works pertaining to physiognomy, perhaps because he was more a theologian of the previous century than the thirteenth in which Albertus was working. For today's philosophers, Anselm is one of

\footnotetext{
${ }^{380}$ Anselm, De Concordia Praescientiae et Praedestinationis et Gratiae Dei cum Libero Arbitrio, 556.

${ }^{381}$ Anselm, De Concordia Praescientiae et Praedestinationis et Gratiae Dei cum Libero Arbitrio, 176.
} 
the most widely known Christian medieval thinkers because of his so-called Ontological argument. However, despite his current status in philosophy and the relatively large number of extant manuscripts of his works that were circulated fairly quickly after their completion, the style Anselm chose to write in was not the most congenial to more philosophical, logical works of later medieval natural science. Gillian Evans notes that they were of a type which did not fit the practical teaching needs of the working schools which were going to evolve in the next generation of two into the first universities. Because of the way the arguments unfold, and their profundity, the books were not easy to lecture on or to divide up satisfactorily for quotation or extract in florilegium or commentary. ${ }^{382}$

This difficulty in integrating Anselm into the university curriculum helps to explain why Albertus's use of Anselm was relegated to his more strictly religious works.

Additionally, Anselm did not have access to most of the Aristotelian works upon which Albertus was commenting.

Abelard, another medieval thinker well-known by modern philosophers, is not cited in Albertus's work and is not mentioned by Albertus as an authority in any of his works. Nonetheless, Abelard's ideas, had they circulated enough despite his infamy for Albertus to have considered them, would not have been a direct impediment to physiognomy. For Abelard, forms are "particular things, each essentially discrete and

${ }^{382}$ G.R. Evans, "Anselm's life, works, and immediate influence," in The Cambridge Companion to Anselm, eds. Brian Davies and Brian Leftow (Cambridge University Press, 2004), 24. 
each of which might not have attached to the substance to which it in fact attaches." ${ }^{383}$ In other words, there are no universals, only particulars. Abelard was also an Aristotelian without knowing Aristotle, and so like Aristotle he supposed that forms had no ontological status separate from the matter that they shaped. However, there was one key difference between Abelard and Aristotle, namely, that human beings were the exception because their forms were their immaterial, immortal souls. Indeed, because human souls can exist outside of the body, "they are not forms after all, though they act as substantial forms as long as they are joined to the body." ${ }^{384}$ This ability of the soul to act as a form would have no doubt pleased Albertus if he had come across it when commenting upon physiognomy in De animalibus, but there is no evidence to support that the Dominican used Abelard's works extensively, and certainly not for this purpose.

William of Conches (1090-1154) is another theologian with whom Albertus was likely to have been familiar. His Dramaticon, or, A Dialogue on Natural Philosophy, was written between 1144-1149 and dedicated to Geoffrey Plantagenet (1113-51), then Duke of Normandy. Although he admits he does not know whether the soul joins the body at conception, at quickening, or even at birth, William does offer a basic description of the soul: "The human soul is spirit that, joined to the body, affords people the ability to discern and understand." 385 But the "Duke" in the dialogue asks why something as good as the human soul would love something as corrupt as the post-lapsarian body. In

\footnotetext{
383 John Marenbon, The Philosophy of Peter Abelard (Cambridge: Cambridge University Press, 1997), 150.

${ }^{384}$ Marenbon, The Philosophy of Peter Abelard, 174.

${ }^{385}$ William of Conches, A Dialogue on Natural Philosophy (Dragmaticon Philosophiae), trans. Italo Ronca and Matthew Curr, (University of Notre Dame Press, 1997), 168, 170.
} 
response, William first clarifies the situation, noting that "the soul is neither attached to, nor mixed, nor fused with the body, but joined together with it." ${ }^{386}$ His answer seems almost classical, including mentioning Plato is claiming that the soul is attracted by the harmony of the four elements in the human body. His discussion of the soul's relation to the body continues:

And if we were to speak truly and properly, we should say that soul loves not the body, nor its qualities, but proportion and harmony by which the parts of the body are joined together. So the soul seeks whatever preserves that proportion and shuns whatever destroys it. But as soon as the elements begin to be at variance with one another, the soul shuns the body and separates itself from it. ${ }^{387}$

This passage from William both maintains the hierarchy of man's makeup, with the soul at the pinnacle, and provides an explanation for aging and death: as the body ages it gradually loses its harmony until the soul loses interest.

In a related section, William describes the body as destined for destruction. But here the body is given a nobler role, and William offers a description of each man's ability to choose the manner of that destruction:

If you enslave yourself to idleness and inactivity, you will be destroyed by the rust of wanton indulgence. But if you devote yourself to some

\footnotetext{
${ }^{386}$ William of Conches, Dragmaticon Philosophiae, 169.

${ }^{387}$ William of Conches, Dragmaticon Philosophiae, 169.
} 
valuable study, you will be of use to others, and your fame will shine forth, but your body will be consumed: whatever you do, woe to the body.

Choose which of the two you prefer: be idle or active: decay follows idleness, but it is the decay of rust; decay follows work, but then it is a glorious decay. The former will earn you perpetual death, the latter incorruption and an endlessly blessed life. ${ }^{388}$

For William, even though the body is doomed, there is hope for the soul connected to it. The soul can join the body in its "rust," or it can devote itself to study, good works, and contemplation of God and put the body's consumption to good use.

Overall, then, the classical, Islamic, and early medieval sources available to thirteenth-century theologians in Latin Christendom had been unable to draw a complete picture of what the soul was. These sources and theologians had, however, been able to provide a picture of the natural state of the soul as one that either informs or perfects a body, and that has control, through will, over that body. Christian theology had further discussed the importance of the possibility of original sin causing a corruption of natural order, allowing the body's appetites and lust to change the soul.

\section{Albertus's Synthesis}

As we have seen, Albertus's own views on the soul had to contend with a rich tradition from Greece and Late Antiquity, from the Islamic world, and from Christian thinkers, traditions that had integrated physiognomy into their worldviews as well.

${ }^{388}$ William of Conches, Dragmaticon Philosophiae, 57. 
However, it seems that these theories of the soul, as synthesized by Albertus and his contemporaries, were uniquely situated to absorb physiognomy as a science at its introduction from the translation efforts.

As noted above, Albertus's theory of the soul is thoroughly saturated by his work as commentator for the entire Aristotelian corpus. His own De anima, therefore, mirrors Aristotle's in many ways. Like Aristotle, he discusses the theories of previous thinkers, including those of antiquity such as those who defined the soul as that which makes man self-moving. ${ }^{389}$ Albertus also wrestles with the spiritual vs. corporeal nature of the soul, trying to understand which parts are the former and which the latter, while also questioning the way in which they are joined. He concludes that there is a certain universal power of the spiritual soul that oversees all the others. ${ }^{390}$ The Dominican also follows more than Avicenna's model of cognition and the intromissionist theory of vision in both his work and Aristotle's. Additionally, Albert uses the emerging term "species" for the formal representations in the eye and common sense, a trend that left "forma" less entrenched in cognition and more open to other uses in physiognomy. ${ }^{391}$

However, the question remains of how Albertus treats the soul in De animalibus, which contains his physiognomy. Despite the fact that physiognomy and man's physiology are covered in the earlier portion of the lengthy work, information on the soul is scattered throughout, with important information discovered in sections on man,

${ }^{389}$ Albertus, De anima, 157.

${ }^{390}$ Albertus, De anima, 4. In spiritualibus autem dicimus, quoniam spiritualia potentiae quaedam sunt, et habent suas partes naturales potestates, ex quibus constituitur quoddam universum suae potestatis, sicut apparet in urbanitatibus.

${ }^{391}$ Smith, Sight to Light, 248. 
generation, birds and other animals, etc. From these there are five basic questions to answer from Albertus's own words: What is the soul? How are body and soul connected? What can generation tell us about the soul? What can animals tell us about the soul? And what does Albertus's model of cognition tell us about the soul?

His statement that it is right to study the parts of the soul because it is these that differentiate animals provides much explanation for the abundance of his discussion of the soul in a work on animals. ${ }^{392}$ As a further introduction to the parameters of discussing the soul, Albertus follows the lead of his intellectual forbears and asks whether a natural philosopher should consider all souls or individual souls. His answer gives us basic information that "we ought not speak of the whole soul or every soul, but we ought to speak of it in accordance with the way by which it is the principle of animals that are generated or corrupted. ${ }^{, 393}$

In other words, it is the same principle of animal life described by Aristotle. Not surprisingly, much of Albertus's definition and language remains Aristotelian, describing the soul as "the formal and final principle of animals." ${ }^{394}$ Albertus also lends his voice to Aristotle's argument that the soul is not fire nor made up of any of the other elements, writing,

${ }^{392}$ Albertus, De animalibus. Kitchell, 872.

${ }^{393}$ Albertus, De animalibus. Kitchell, 872. Stadler, 775. Quia debemus loqui de causis formalibus animalium et membrorum eorum, non debemus etiam loqui de tota et omni anima, sed secundum illum modum quo est principium animalium generatorum et corruptorum, debemus loqui de ipsa.

${ }^{394}$ Albertus, De animalibus. Kitchell, 870. Stadler, 773. Anima formale et finale principium animalium. 
It is better to say that the soul is the principal cause of the body (that is, the sustenance), containing it, and that it is this way in this sort of body which is hot and possess the other powers of the elements. Or it is better to say that the soul is the sort of cause as we mentioned belonging to this sort of body and that these qualities of the elements are its instruments. Thus, to say that the soul is fire has the same force as saying that the saw is the woodworker. For these reasons, and those like them, the soul must necessarily be an act of the body, having the heat of the fire that is in the body just as a mover and an artisan does in a power of this sort." 395

Albertus also follows the traditional Classical tripartite model of the human soul. He calls the most basic soul vegetative, that part of the soul that gives the living thing its powers of nutrition, growth, and reproduction. The addition of the sensible soul to the vegetative belongs to animals, those living creatures that can sense, some more perfectly than others. The final part of the soul, which is unique to humans, is the rational soul. In turn he adds something from the recent translations of Arabic thinkers by following Avicenna in speaking of souls as perfections, though to different degrees, depending on what form of life they are attached to. Albertus writes, "And because for every diversity

\footnotetext{
${ }^{395}$ Albertus, De animalibus, Kitchell, 937. Stadler, 843. Melius est dicere quod anima sit principium et causa corporis sive sustentatio continens ipsum, et sic in tali corpore quod est calidum et alias virtutes habens elementorum, aut quod anima sit talis causa talis corporis qualis dicta est, et quod istae elementorum qualitates sint instrumenta eius: et ideo dicere animam esse ignem idem valet quod serram dicere fabrum lignarium

esse. Ex hiis ergo et huiusmodi rationibus necessarium est, quod anima est actus corporis habens sicut motor et artifex in potestate huiusmodi calorem ignis qui est in corpore.
} 
of the movers there is a proportionally corresponding diversity of the movables from the movers, there is therefore also a difference of nobility in the nature of the complexions of the organic bodies which are perfected by these souls." 396

At the most basic level, then, we can see that Albertus is not particularly controversial, instead following the lead of his intellectual forbears, rejecting what had been rejected by great authorities for almost two millennia, such as the soul being a harmony itself or made of elemental fire. He also includes more recent terminology, such as Avicenna's notion of the soul as a perfection. ${ }^{397}$ But what of his concept of how the soul interacts with the body?

In short, for Albertus, the body is the tool of the soul, a corporeal entity that is only truly a person (or animal or plant) when activities of the soul are carried out by bodily members. ${ }^{398}$ Overall, Albertus gives us no clear answer to where the soul ends and the body begins, noting that we cannot determine exactly where the animate ends and the inanimate begins. ${ }^{399}$ However, it is certainly possible to gain clues about his idea of what humans can understand about the connection between soul and body.

One of these clues is the importance of man's position as the bridge between the earth and the heavens in the hierarchy of the world. Man has his vegetable and sensible

\footnotetext{
${ }^{396}$ Albertus, De animalibus, Kitchell, 1192. Stadler, 1097. Et quia omni diversitati motorum respondet etiam proportionaliter diversitas mobilium ab illis motoribus, ideo etiam differentia nobilitatis est in natura complexionis corporum organicorum quae perficiuntur ab istis animabus.

${ }^{397}$ See also Kitchell, 1401.

${ }^{398}$ Albertus, De animalibus. Kitchell, 49.

${ }^{399}$ Albertus, De animalibus. Kitchell, 587.
} 
souls, but his rational soul is not just what sets him apart from animals, but also what connects him to God. Indeed, the rational soul is what is meant by God making man in his own image. The rational soul is the one that "through the divine power which it has and through its intellectual and animal power, is an image of the first cause, a likeness of intelligence, and an example of celestial life."400 For Albertus, all living things have a bit of "the nature and the substance of heaven" added to the elements, which is why souls are what makes a body alive, but man is the most perfect of the animals and therefore closest to the heavens and God. ${ }^{401}$

Albertus also discusses the relationship of the soul with body in terms of where it is in the body and how it is related to various parts. After making it clear that there is only one, united soul in each body, and referring his reader back to his own De anima on that point, in book sixteen of De animalibus he writes,

It is clear that in each member there is some potency of the soul which is a potency for life. Now in one it is nearer and in another more removed, as in bone it is more removed and in flesh it is closer. Again, it is clear in the heart but is more hidden in the liver and brain. For these are insensible and for this reason both uniform and non-uniform members are related

\footnotetext{
${ }^{400}$ Albertus, De animalibus. Kitchell, 1401. Stadler, 1313. Quia illa per virtutem divinam quam habet, et per intellectualem virtutem et animalem, ymago est primae causae et similitudo intelligentiae et exemplum vitae caelestis.

${ }^{401}$ Albertus, De animalibus, Kitchell, 1373.
} 
unequally to the potency for life and for this reason they are also related unequally to the soul. ${ }^{402}$

This excerpt tells us that the soul is in every part of the body, though unequally. For Albertus this is determined by how close each member of the body is in its make up to the most perfect, sensing members; the heart, and those members most like it. Therefore warm, moist, soft parts of the body are in more direct contact with the soul than those that are hard, cold, or dry, like bones. Presumably, the soul is equally willing to connect with each part of the body but is blocked to varying degrees by the material nature of each member.

While no member of the body is without the soul, the converse is not true.

Albertus writes,

From these things, then, we can tell that the intellectual soul, which not only has passiones and operations in things which lack material (such as sensation and imagination) but which has them without any bodily organ, cannot in any way come from any material principle. Rather, it is influenced by the light of a separate intellect, which is the first principle and the most powerful agent [operator] of nature's entire work. ${ }^{403}$

${ }^{402}$ Albertus, De animalibus, Kitchell, 1179. Stadler, 1084. Quod in quolibet membro sit aliqua animae potentia quae est potentia vitae. In quodam tamen est propinquior et in quodam remotior: sicut in osse est remotior et in carne propinquior: et adhuc

in corde manifesto et in epate et cerebro ocultior: eo quod haec sunt insensibilia: propter quod tarn similia quam dissimilia membra inaequaliter se habent ad vitae potentiam, et propter hoc etiam inaequaliter se habent ad animam.

${ }^{403}$ Albertus, De animalibus. Kitchell, 1206. Stadler, 1112. Ex hiis autem est advertere quod intellectualis anima quae non modo habet passiones et operationes in hiis quae sunt sine materia, sicut sensus et ymaginatio, sed etiam habet eas sine organo corporis, non 
If sensation and imagination "lack material," then the body is indeed not a part of every faculty of the soul. The reason for this that Albertus gives, the influence of the light of a "separate intellect," is from the divine illumination theory popular in Albertus's day. A theory with ancient roots and popularity from Augustine through the Scholastics, divine illumination holds that in order to reach true understanding, man relies upon the light of Christ being shown upon the process of thinking. This does not mean that God does our thinking for us but that he is necessary for the highest functions of the rational soul to be completed. For Albertus, light plays another important role, that of a sort of connector between body and soul. He writes, "Again, since the vehicle for the soul into the members is the substance of light in the body (much as the light of the heavens is the vehicle for the mover of heaven into all matter), light, then, must be midway between the nature of the soul and matter."404 Divine illumination is thus a way of bridging the gap between the physical world of the senses and the incorporeal one of the human soul's powers of cognition.

Yet Albertus also states that the soul cannot operate without a body. When discussing the difficulties of ancient opinions on the nature of sperm, Albertus tells us: "For since both the soul in and of itself, and every part of the soul is the substantial form [etelechya] of an organic body, neither the soul nor any part of the soul can operate where

potest aliquo modo esse ex aliquo materiali principio sed influitur a lumine intellectus separati qui est primum principium et potissimus operator totius operis naturae.

${ }^{404}$ Albertus, De animalibus. Kitchell, 1373. Stadler, 1287. Amplius cum sit vehiculum animae in membra substantia lucis in corpore sicut lux caeli vehiculum est motoris caeli in totam materiam, oportet lucem ipsam mediam esse inter naturam animae et materiam. 
the organs have not already been formed."405 This seems dangerously close to denying the soul some of its key attributes when separated from the body, if not going as far as Averroes and some of the classical and antique thinkers.

The necessity of the body for the soul and the converse is not the only important aspect found in the chapters dealing with generation. In fact a great deal about the soul can be found, echoing questions such as whether souls are inherited from parents and when the body and soul are joined. One of the greatest difficulties to be addressed is what portion of the soul is contained in semen. Some portion of it must be present since life begins, at least vegetative life, as soon as conception occurs. Albertus solves this problem in part by emphasizing that it is the "act of the soul" which is transmitted, that it is "a likeness of the power of his members and is not a soul properly speaking." 406 This likeness is "the principle of creation and formation of all the other members," beginning in the heart before spreading out to other members. ${ }^{407}$ Once the "entire being has come together it will be animated and will be moved by the soul toward completing the members." ${ }^{, 408}$ This would seem to create a straightforward account of ensoulment: the

${ }^{405}$ Albertus, De animalibus. Kitchell, 1163. Stadler, 1068-69. Cum enim tam anima in se quam omnis pars animae, sit entelechya corporis organici, non potest anima vel aliqua animae pars operari ubi non sunt iam formata organa.

${ }^{406}$ Albertus, De animalibus. Kitchell, 1191. Stadler, 1096. Quod enim transfunditur actus animae, est maris et similitudo virtutum membrorum eius et non anima proprie loquendo.

${ }^{407}$ Albertus, De animalibus. Kitchell, 1202. Stadler, 1108. Et deinde a corde sicut a membro primo diffunditur virtus, quae est principium creationis et formationis aliorum membrorum omnium secundum ordinem.

${ }^{408}$ Albertus, De animalibus. Kitchell, 1202. Stadler, 1108. Et postquam totum simul coagulatum fuerit animatum, movebitur ab anima ad complendum membra. 
original generative power of conception is an outside "image" of the soul of the father, introduced through the sperm and causing the original growth of the embryo and members until the body is ready for ensoulment. ${ }^{409}$ Yet, in the same book (sixteen) Albertus takes this point a bit further, noting that members formed by an outside power cannot have souls, since a soul is an internal power, but that formed parts cannot exist without souls. ${ }^{410}$ This leaves the nature of the soul in an early embryo uncertain. However, about six weeks after birth, it is clear not only that the ensoulment has taken place, but also that all three parts of the tripartite soul are being utilized:

The young child smiles on or about the fortieth day and this is the first activity which the rational soul produces in its body. . . It dreams after two months, but forgets them. The reason for this is that although the sensible forms remain in its memory and flow to the front of its head during the dreams, nevertheless, because that part is very moist and soft, they do not stay there. ${ }^{411}$

\footnotetext{
${ }^{409}$ Albertus, De animalibus. Kitchell, 1203. Albertus does credit the mother with the first bit of nutritive power.

${ }^{410}$ Albertus, De animalibus. Kitchell, 1161.

${ }^{411}$ Albertus, De animalibus. Kitchell, 826. It is also this excessive moistness, Albertus explains, that makes babies more susceptible to disease. Stadler, 729. Natus autem parvulus ridet $X L$ die vel circa hoc, et haec est prima operatio quam lacit anima rationalis in corpore suo, quoniam haec non convenit aliis animalibus. Somniat autem

post duos menses, sed obliviscitur somniorum: et huius causa est, quia licet tunc in memoria eius rernaneant formae sensibiles et fluant ad anterius capitis in somnis, tamen quia ilia pars multum est humida et mollis, non manent.
} 
But how does the rational soul enter the body in utero, even if Albertus is not sure of exactly what happens between conception and ensoulment? He notes that reason is "not joined to any part of the body as if it were the act of any given member," and so it is "led into the fetation" not through the matter or body but rather by "the light of the first acting intellect. For this intellect is pure, unmixed, and impassible." ${ }^{412}$ The rational soul is different from the vegetative and sensitive insofar as "neither the spirit of the sperm nor any heat seems to act on this one" because "it is the act of no body or of any part of the body. ${ }^{, 413}$ All of this information, deeply entwined in discussions of procreation, sperm, and gestation, gives a picture of a soul that has varying levels of ability to be influenced by the physical world, with the rational soul, the image of God, the connection with the celestial realm, being left either difficult or impossible to corrupt while the vegetative and sensible souls are much more of the temporal world formed by the four elements and therefore more susceptible to them, despite their incorporeality.

However, Albertus seems to contradict himself when he continues the discussion, noting that after "the heart and brain have been formed, then the rational soul is infused, even though it is then superseded by the sensible soul. For the rational soul still remains

${ }^{412}$ Albertus, De animalibus. Kitchell, 1189. Stadler, 1094. Ratio non sit coniuncta alicui parti corporis sicut actus alicuius membri existens, quod oportet quod nec ex materia nec per instrumenta corporea inducatur in conceptum, sed potius ab eo quod non commiscetur alicui materiae corporis nec aliquibus virtutibus quae sunt in materia seminis agentes. Et ideo principium ipsius nichil aliud est nisi lux primi intellectus agentis. Intellectus enim hie purus est et immixtus et impassibilis.

${ }^{413}$ Albertus, De animalibus. Kitchell, 1190. Stadler, 1095. Nec spiritus spermatis neque calor aliquid operari videtur: sed videtur tantum causari a lumine intellectus primi qui operatur in opere naturae, eo quod nullius corporis vel partis corporis est actus. 
material since it has not yet been differentiated. Rather, in such cases it will be present as it is in a drunkard or in an epileptic." ${ }^{414}$ This is because a man cannot be changed from one species to another, and "if a boy be said at first to have sensible substance, and afterward to gain possession of a soul or rational substance, he will be changed from species to species and from one substantial form to another, an absurd thing to say.",

Just as generation can be mined for Albertus's conception of the soul, questioning what can be learned from his discussions of animals other than man is also important. In part, animals are important because they are a foil for man, providing the middle of the hierarchy of earthly souls. Part of the reason that man stands above animals in this hierarchy is that animals are more passive than active in their relations with nature. Albertus notes that "John the Damascene says that it is more that animals are acted upon by nature than that they act upon anything out of a freedom of the soul, or from imagination or thought." $" 416$

The lowest of animals have what Albertus refers to as "confused souls." These include aquatic, soft-shelled "swimming" creatures that lack the "noble" internal organs

${ }^{414}$ Albertus, De animalibus. Kitchell, 1203. Stadler, 1108. Quando autem cor et cerebrum formata sunt, tune iam infunditur anima rationalis, licet tunc superetur ab anima sensibili quia rationalis diu adhuc manet materialis eo quod nondum adhuc erit discreta, sed potius in talibus erit sicut est in ebrio et epylentico.

${ }^{415}$ Albertus, De animalibus. Kitchell, 1203. Stadler, 1108-09. Si enim puer diceretur primo habere substantiam sensibilem, et postea adipisceretur animam vel substantiam rationalem, permutaretur de specie ad speciem et forma substantiali ad formam: quod dicere est absurdum.

${ }^{416}$ Albertus, De animalibus. Kitchell, 667. Stadler, 571. Propter quod etiam Johannes Damascenus animalia magis agi dicit a natura quani agentia aliquid ex libertate animae aut ymaginatione aut cogitatu. 
(heart, liver, brain). He writes, "just as the formative power which is in their semen produces a confused function in the noble members, so too the sensible soul in them infuses its powers into the members confusedly and produces a confused function in them through its powers." 417 These swimming creatures also have "confused" phantasies, estimations, and memories.

Other animals are closer to man, such as birds, though aquatic birds are least perfect and "almost universally poor for instruction," while birds of prey, such as eagles have more perfect souls. ${ }^{418}$ Eagles have "perfect" sensible souls and the potencies of sense and motion that "the ancients used to say differentiated an animate object from an inanimate one.. ${ }^{, 19}$ They also have all the senses man does, further explaining their high status in the hierarchy of animals. Indeed, birds are so important that Albertus devotes an entire book of De animalibus to them, giving each species of bird its own chapter in a long, single tract.

In another area of De animalibus, Albertus's model of cognition reveals a focused source of information based on man's rational soul. In this, Albertus adheres to Avicenna's formulation of internal senses and three brain ventricles, allowing for the common sense and "its anatomical and physiological connection to the eye via the optic

${ }^{417}$ Albertus, De animalibus. Kitchell, 1431. Stadler, 1341. Quia sicut formativa quae est in seminibus eorum, confusam nobilium membrorum facit operationem, ita anima sensibilis in eis confuse influit membris vires suas et confusam facit in eis per vires operationem.

${ }^{418}$ Albertus, De animalibus. Kitchell, 1426.

${ }^{419}$ Albertus, De animalibus. Kitchell, 1544. Stadler, 1430. Ideo ea duo quibus antiqui animatum ab inanimate differre dicebant. 
nerves." ${ }^{420}$ The common sense is meant to "be a center of sensation" and is placed at the front of the head, in the anterior ventricle of the brain, so that "the sensibles of all the senses might be confined in one place and thus not flow off." ${ }^{\text {"421 }}$ Following Avicenna's model further, the estimative power [aestimatio], imagination (retentive and compositive), phantasy, and memory are also placed in the ventricles.

However, despite agreeing with Avicenna and placing the faculties of the soul in the three ventricles of the brain, not all faculties of the soul are completely rooted in the body for Albertus. He notes that the rational soul is "one substance" "from which flows the vegetative potencies, as well as the sensible and intellectual ones of which some are implanted in the body and some are not." ${ }^{, 22}$ Those faculties not rooted in the body are "a certain likeness of the light of the intellect acting in the nature and principles of the sperm." ${ }^{423}$ Thus the bodily faculties are "likenesses" of divine light in the same way that a likeness of the soul is present in sperm enough to begin the actions of the nutritive soul at conception.

The vegetative soul's faculties are all rooted in the body, "for nourishing is accomplished only by a corporeal, material body, and the same is true for growth and

${ }^{420}$ Smith, Sight to Light, 247. Smith also notes that Albertus uses "species" for "formal representation of the object in the eye and common sense" and that by c. 1250 species was used almost exclusively (no longer forma and species interchangeably as they had been since Augustine).

${ }^{421}$ Albertus, De animalibus. Kitchell, 947-48.

${ }^{422}$ Albertus, De animalibus. Kitchell, 1188-1189. Stadler, 1093. Qua effluunt potentiae vegetativae et sensibiles et intellectuales quarum quaedam affixae sunt corpori et quaedam non.

${ }^{423}$ Albertus, De animalibus. Kitchell, 1189. Stadler, 1094. Sed potius illae sunt quaedam similitude lucis intellectus agentis in natura et principiis spermatis. 
generation. ${ }^{, 424}$ In other words, the forms of the vegetative soul are completely mixed with the body. Meanwhile, the sensible soul has some faculties, or forms, that are not mixed with the body. Albertus describes these as operations and passivities (passiones), "which have no share at all with the material." ${ }^{425}$ Albertus's example of this is the medieval trope of the sense acting like wax, taking on an impression of the sensible being sensed, but doing so "entirely without material." This leaves the rational, or intellectual, soul to have not just operations and passiones "in things which lack material (such as sensation and imagination)," but it does so without "any bodily organ," instead being "influenced by the light of a separate intellect, which is the first principle."

Because of its ties to cognition and his interest in physiology, the eye itself is of keen interest to Albertus. He presents a very detailed, if not incredibly clear, description of the eye. The eye, for Albertus, is made up of seven "tunics," all but one of which arise from materials of the optic nerve and its surrounding membranes. The optic nerve itself is hollow and carries a refined spirit suitable to vision, which he calls the virtus visiva. The central portion of the connection between brain and eye is made of nerves and veins, with outer membranes made of the pia mater and dura mater of the brain. The nerve portion turns into the retina in the rear of the eye and the aranea (retina) at the front. The

${ }^{424}$ Albertus, De animalibus. Kitchell, 1205. Stadler, 1111. Nutrire enim non fit nisi cibo corporeo materiali et similiter augere et generare.

425 Albertus, De animalibus. Kitchell, 1205. Stadler, 1111. Sed sunt quaedam formae quae habent operationes et passiones in nullo communicantes cum materia.

${ }^{426}$ Albertus, De animalibus. Kitchell, 1206. Stadler, 1112. Ex hiis autem est advertere quod intellectualis anima quae non modo habet passiones et operationes in hiis quae sunt sine materia, sicut sensus et ymaginatio, sed etiam habet eas sine organo corporis, non potest aliquo modo esse ex aliquo materiali principio: sed influitur a lumine intellectus separati qui est primum principium et potissimus operator totius operis naturae. 
pia mater portion turns into the secundina and forms the uvea, or iris, at the front of the eye. The third portion, from the dura mater, opens up to form the scliros, or sclera, which becomes the cornea at the front of the eye. The lens toward the front of the eye provides a flat surface for proper vision while also dividing the vitreous humor from the albugineous humor. The seventh "tunic," the conjunctiva, arises from "the subcutaneous tissue, as they say, which is on the exterior part of the seat of the eye" and soothes the eye and eyelid. ${ }^{427}$

To return to how these ideas directly pertain to physiognomy, the eyes do not just provide the most important signs, but do so because they are the link between the corporeal world and the incorporeal powers of the soul. The lens and cornea are thin barriers between the outside, physical world and the visual spirit, which is so closely related to the refined spirit in which incorporeal cognition takes places. In this way the eyes and their ability to see form a theoretical bridge. This deep connection between the soul and vision, between the corporeal world, both bodily and outside of the body, allows Albertus's conception of the soul and the human body not just to have room for physiognomy, but to be strengthened by them. Indeed, the eyes are the most important

${ }^{427}$ Albertus, De animalibus. Kitchell, 123. See pages 120-123 for Albertus's full description of the physiology of the eye. Albertus's own summary is in Stadler, 73-74. "Recapilulantes autem et summatim perstringentes quae dicta sunt, oculi sunt tunicae septem et tres humores. Tunic-arum quidem prima dicitur retina, quae est in posteriori parte occuli, orta a nervo optico qui componitur ex nervis et arteriis. Altera autem, etiam ex parte posteriori, dicitur secundina, cuius ortus est a pia matre cerebri, quae est pannus involvens \& cerebrum. Tertia item posterius claudens humores occuli dicitur scliros, quae oritur a dura matre cerebri: has enim duas pelles secum ad substantiam oculi trahit nervus obticus in operimentum sui. Quarta autem vocatur a quibusdam aranea specialiter, et est ante in oculo, exorta a prima posteriori. Quinta vero dicitur uvea, quae oritur a secunda posteriori, et sexta est cornea, quae oritur a reliquiis tunicae posterioris. Septima autem est conjunctiva, quae oritur a pelle subcutanea, ut dicunt, quae est in exteriori parte sedis occuli." 
part of the body for physiognomy, and Albertus's chapters on the eyes, like those on the less emphasized skin and other outwardly visible bodily members, are an intertwined mixture of anatomy, physiology, physiognomy, and pathology. 


\section{CHAPTER 5:}

\section{Albertus's Physiognomy and Physiognomy Beyond the Thirteenth Century}

Albertus's physiognomy is a part of the overall thirteenth-century effort of synthesizing the Greek and Islamic works transmitted to Latin Christendom through translation in the twelfth century. Physiognomy was at the nexus between these other works of theology and medicine. Indeed it was intertwined with both, dependent on theology for its permissibility, medicine for its current structure, and both for explanations of how the scientia worked. In this regard Albertus seems to be following the path forged by Michael Scotus, as outlined in Chapter 2. What, then, in light of the development of physiognomy, medical and clime theories, and ideas of the soul, did Albertus's physiognomy look like? Piecing it together is a bit less straightforward than looking at Polemon or even Michael Scotus, because the majority of Albertus's physiognomy is in the first book of his De animalibus, and therefore is laid out as a subject secondary to human physiology. Thus, Albertus's physiognomy has more in common with the Islamic medical texts that include physiognomy than with the texts devoted to physiognomy as the primary subject.

\section{The Problem of Sources}

Pierre Jammy published the works of Albertus Magnus in Latin in 21 volumes in $1651 .^{428}$ The sixth volume is Albertus's De animalibus. The next major effort to present a complete Latin version of Albertus's works would not be attempted until the late nineteenth century, when Auguste Borgnet completed a new edition of the Opera

${ }^{428}$ Alberti Magni, Opera Omnia, 21 vol., ed. Pierre Jammy, Paris, 1651. 
Omnia. $^{429}$ This new Opera Omnia has almost twice the number of volumes, but only because Borgnet broke up many of the larger works into two volumes. De animalibus, for instance, occupies both the eleventh and twelfth volumes of the Borgnet edition. However, Borgnet based this new edition upon Jammy's and as a result it replicated many of the errors, including some volumes misattributed to Albertus Magnus, such as the Book of Secrets. ${ }^{430}$

Unlike most of Albertus's works, De animalibus had an early twentieth-century edition. Hermann Stadler produced a Latin edition between 1916 and $1920 .^{431}$ While still not up to modern standards for Latin editions, the Stadler edition is the most recent one. Beginning in 1951 the Albertus Magnus Institute, which is owned by the Archdiocese of Cologne, began to publish a series of critical editions of the entire corpus, working with Aschendorff, the same publisher responsible for the Stadler De animalibus edition. However, the work is moving very slowly, and as of March 2018, there are only 31 published volumes out of a planned 41 volume series. De animalibus is, unfortunately, not yet published in this series of critical editions.

${ }^{429}$ Alberti Magni, Opera Omnia, 38 vol., ed. Auguste Borgnet, 1890-1899.

${ }^{430}$ For a modern edition of this Pseudo-Albertus work, see Michael R. Best and Frank H. Brightman, ed., The book of secrets of Albertus Magnus of the virtues of herbs, stones and certain beasts, also A book of the marvels of the world (Oxford: Clarendon Press, 1973).

${ }^{431}$ Albertus, Magnus. De animalibus, 2 vols., Hermann Stadler, ed. (Münster: Aschendorff, 1916-1920). Stadler also produced an edition of Albertus's De principiis motus processivi, published in 1909. 
However, there is an English translation in two volumes that was published in 1999. ${ }^{432}$ Published roughly eight decades after the Stadler edition, the English edition provides much clearer scholarship. I have therefore used this modern translation extensively, though referring to the Stadler edition for the corresponding Latin. The eventual release of an Aschendorff critical edition in Latin will ultimately solve this problem of sources for future work on Albertus's De animalibus.

\section{Synopsis of Albertus Magnus's Physiognomy}

De animalibus is an extremely lengthy work. In the Jammy edition, it is 684 pages. In the Borgnet edition, the two volumes contain 682 and 665 pages for a total of 1347. The two Stadler edition volumes fill 1664 pages, while the 2-volume Kitchell and Resnick English translation is 1827 pages. However, Albertus's physiognomy is almost entirely contained in the first of the 26 books. This first book of De animalibus, on the members of human bodies, is divided into three parts or tracts: the first on members' diversity, the second on their dispositions, and the third on internal members. The three tracts together contain forty-one chapters. Details on the physiognomic readings will be addressed later in this chapter, but first I will provide a general overview of the contents of De Animalibus's first book.

Central to all of De animalibus is Albertus's use of the term member (membrum). While member has taken on the connotation of a limb or other appendage of the body, Albertus uses it in a much wider sense. This includes limbs, but also organs and smaller

${ }^{432}$ Albertus Magnus On Animals: A Medieval Summa Zoologica Kitchell, Kenneth F. Jr, and Irven Michael Resnick, trans and eds.,2 vols. (Baltimore: The Johns Hopkins University Press, 1999). 
tissues of the body. Membrum is also used for more than human anatomy. Indeed, Albertus applies is just as often, if not more, to animals. For instance, Book 12 is devoted to the cause of animal members of all complexions and kinds. The following two books are dedicated to inner and outer members, with, for example, an entire fourchapter tract in Book 14 on the outer members of ringed animals (anulosorum), shellfish (osteorum), and something he calls malakye. ${ }^{433}$

Human members are likewise the subject of much of Book 1 of De animalibus, and are specifically subject to physiognomic examination. Individual visible members are built from uniform members, according to Albertus. A uniform member is "that which, when the body of the animal is divided, is not divided into the shape of any other member and from which the composition of an animal's body begins. ${ }^{\text {"434 }}$ These members are also evaluated according to their humoral makeup, i.e. moist members include "blood, fat [pinguedo], marrow, sperms, and humors" while dry ones include veins, nerves, and cartilage. ${ }^{435}$ The most perfect animals have nine uniform members: cartilage, nerve, cord, ligament, artery, vein, pannicular-membrane (panniculus), and "the flesh that fills the empty places."

${ }^{433}$ Malakye is difficult to decipher and Kitchell and Resnick leave it in the Latin. However, it is a creature that Albertus notes is somewhere between an octopus and a hard-shelled animal; 1051-52, Stadler, 957-58.

${ }^{434}$ Albertus, De animalibus. Kitchell, 48. Stadler, 5 Est igitur membrum quoddam animalis, in quod cum divisum sit corpus animalis non dividitur in formam membri aliam, et aquo incipit compositio corporis animalis.

${ }^{435}$ Albertus, De animalibus. Kitchell, 53. Stadler, 10. Sicut sanguis, pinguedo, medulla, spermata et humores.

${ }^{436}$ Albertus, De animalibus. Kitchell, 70. Stadler, 26. Oportet enim nos non latere, quod, sicut diximus, membra quaedam sunt similia: et haec sunt in animalibus perfectis 
After establishing the building materials of human and other animal bodies, Albertus spends the majority of his first book devoting each chapter to a different visible or internal human member or set of related members in a fashion very similar to a medieval work of medicine or other medieval works devoted to physiognomy. Given the importance of animal likenesses in physiognomic readings and the titular topic of $D e$ animalibus, the reader can be forgiven for initially expecting to find physiognomic readings organized by animal likenesses in Albertus's work. Instead, Albertus's physiognomy occupies a supporting role in his chapters on humans, the most important animal, and more specifically human physiology. ${ }^{437}$

It is in the second tract, addressing the visible members of the human body, that physiognomy is most prominent. Indeed, the second chapter of the second tract provides a rationale for the study and use of physiognomy. Albertus writes, "The natural inclinations of human dispositions and their lifestyles can be described based on indications arising from their natural members ... This is why the science of this chapter is called physiognomy, since it teaches one to make predictions about human dispositions using the physical shapes of their members." 438 This description makes it clear, among

sanguinem habentibus novem: os videlicet, cartillago, nervus, corda, ligamentum, arteria, vena, panniculus, quo membra involvuntur, et caro, quae supplet vacuitates.

${ }^{437}$ Physiology is an anachronistic term, but it is the best explanatory term for what Albertus was exploring, namely, the functions of the parts of the body and not simply anatomy.

${ }^{438}$ Albertus, De animalibus. Kitchell, 93. Stadler, 46: Qui tamen ornnes ex instinctu naturae causantur: oportet etiam de moribus hominum mentionem facere, secundum quod a uuturalium membrorum signis declarari possunt naturales hominum inclinationes affectuum et regimina vitae. . . Propter quod etiam scientia capituli istius physonomia dicitur, quia divinare docet de affectibus hominum per physicas formas membrorum. 
other things, that Albertus is both proposing the validity of physiognomy and calling it by its classical name.

The next (third) chapter addresses the queen of physiognomic subjects, the eye. After all, Albertus tells us, "the entire perfection of physiognomy exists in the eyes."439 Following the eyes, there are chapters devoted to the ears, the bones of the head, and more, with the appropriate mentions of physiognomic signs and readings. The nose, cheeks, jaw, mouth, tongue are all covered in such a way. However, it is worth mentioning that Albertus devotes multiple chapters to pure physiology without mentioning physiognomy at all. For example, after a discussion of the tongue in chapter 10, chapters 11-21 feature no physiognomy, instead focusing on the bones and muscles of the human body. Four of the five last chapters of the tract contain a great deal of physiognomy, just as the ones on the parts of the head, face, and eyes do.

The third tract of the first book deals with the internal members, largely meaning what we would think of as organs, but not exclusively. Accordingly, Albertus deals with the brain, esophagus, windpipe, lungs, stomach, intestines, heart, diaphragm, liver, spleen, gall bladder, and kidneys. These subjects offer few opportunities for the inclusion of physiognomic readings because of their hidden nature. The exceptions include a discussion of breath when dealing with the lungs and the seventh chapter on the skin, which also contains some physiognomic information.

${ }^{439}$ Albertus, De animalibus. Kitchell, 99. 


\section{Albertus's Physiognomy and Humoral Medicine}

The layout of Albertus's physiognomy, therefore, has most in common with physiognomic works that list their readings by body sign, from head to toe in a medical fashion. His comfort with the medicalization of physiognomy is clear from this inclusion of it in a first book otherwise devoted to anatomy, physiology, and humoral medicine. This reliance upon the importance of humors is emphasized in the third tract of the first book in the midst of a discussion of the heart and lungs. Here he discusses outward signs, or mannerisms, that can reveal not the inner character of a man, but instead the inner character of his heart, i.e. its complexion. For example, he tells his reader, "Both lack of chest hair and a small amount of it tell of coldness and dryness of the heart." On the other hand, warmth of the heart's humoral complexion is signified, "when the mannerisms include natural and unpremeditated boldness and ferocity" or "the bodily mobility that does not allow a man to stay in one place whether standing or sitting." ${ }^{441}$ It seems that in Albertus's thinking, the physiognomic signs are to be analyzed with no less logical thinking and care than those of humoral medicine. Indeed, he entwines the two in De animalibus.

In light of the importance of Greek humoral medicine in De animalibus and Albertus's physiognomy, it is worth noting that he is not slavishly devoted to Galen any more than he is slavishly devoted to Aristotle. Galen was, after all, not a physiognomer

\footnotetext{
${ }^{440}$ Albertus, De animalibus. Kitchell, 269. Stadler, 209. Nuditas autem pectoris et paucitas pilorum dicunt cordis frigiditatem aut siccitatem.

${ }^{441}$ Albertus, De animalibus. Kitchell, 269. Stadler, 209. Mores quidem quoniam ira naturalis et audacia impraemeditata et furiositas cordis significant caliditatem et similiter corporis mobilitas quae non permittit hominem diu consistere in loco uno stando vel sedendo.
} 
despite living in the midst of a Mediterranean world most familiar with the subject. Yet he did not author works of physiognomy, in part because the medicalization had not yet occurred and physiognomy was not a science in his day in the sense that it did not look for causes. Albertus corrects Galen on this point. He notes that man has the most purified of animal complexions and that he has many powers of the soul that affect the body. ${ }^{442}$ In other words, the body is caused by the soul to some extent, meaning that physiognomy entails looking for the soul-based causes of physical accidents. Albertus later gives a direct cause for physiognomy's efficacy, writing, "Since, therefore, the shape and appearance of the members are both generated and nourished by blood, it follows that the inclinations of the passions can, to some extent, be understood from actual appearance.”443 Physiognomy is therefore perfectly logical in the causal, Aristotelian sense.

In terms of other sciences, while there is not any astrology per se in De animalibus, there are a few references to the relationship between medicine and the structure of the universe. The best example is when Albertus writes about the heart as the principal among the organs, saying, "The heart is therefore to these [organs] as the first mover is to the celestial spheres, for it is composed of mover and movable ... And the power of the heart is just as the power of the light of the sun to which all other things

${ }^{442}$ Albertus, De animalibus. Kitchell, 86.

${ }^{443}$ Albertus, De animalibus. Kitchell, 94. Stadler, 47. Cum igitur membrorum figura et habitudo et generentur et nutriantur ex sanguine, sequens est, quod ex ipsa habitudine membrorum aliqualiter cognoscantur inclinationes passionum. 
direct themselves." ${ }^{444}$ While Albertus keeps this explanation fairly brief, it does show the common view of the Ptolemaic universe and its reflection in the human body in the midst of a book that includes copious amounts of physiognomy, albeit physiognomy that is not directly tied to the universal model.

That the relationship of physiognomy to humoral medicine and physiology is of the utmost importance in Albertus's first book of his De animalibus is upon examination quite evident. However, this emphasis on the medicalization of physiognomy and its relationship to other sciences does not exclude the other major categories of readings, namely those based on animals, the masculine/feminine binary, and geography.

\section{Albertus on the Kinds of Physiognomy}

Albertus also uses his theoretical chapter (Tract 2, Chapter 2) to delineate a specific kind of physiognomy familiar to most physiognomers. This type, he suggests, is based upon the differences between masculine and feminine traits. This is important, according to Albertus, because those with more masculine physical traits will have masculine characters. Men are "eager to attack, easily angered, generous, open, not easily dulled or gotten around by any artifice or trick, victorious through virtue, zealous, great-hearted, and vigorous." 445 Women, on the other hand, are "compassionate, envious,

${ }^{444}$ Albertus, De animalibus. Kitchell, 72. Stadler, 27. Et ideo cor in hiis est sicut in speris celestibus est primus motor motus: hic enim compositus est ex motore et mobili: et quicumque alii sunt motores moti, virtutes movendi accipiunt ab ipso primo composito motore moto: et virtus cordis est sicut virtus luininis solis, cui applicantur omnia alia, et accipiunt virtutem ab ipso, et tune possunt peragere suas operationes.

${ }^{445}$ Albertus, De animalibus. Kitchell, 95. Stadler, 47. Videmus igitur masculinum animum ut in pluribus vehementem esse ad impetus, facilis odii, liberalem, apertum, qui 
easily give way to passions, cannot abide hard work, and are bitter, cunning, and timid."446 However, Albertus begins almost immediately afterwards with a head to toe analysis of the human body, including physiognomic signs and their readings as he goes. This organization by body part begins before his theoretical chapter has even ended, namely discussions of the hair, eyebrows, and eyelids.

Beyond the introductory notes in the first tract of the first book, among the discussions of individual body part, there are examples of masculine and feminine signs and readings. For instance, he notes in a discussion of the feet that in women flat footedness,

is a sign of a clever and malicious disposition. For this is a sign of cold phlegm being more abundant than the formative power. Such a person receives forms easily and is moved easily, even by a weak mover. This is the reason for female cleverness in petty, useless, and harmful matters, and, according to Pythagoras, it indicates a bad disposition in women. ${ }^{447}$

This example matches the general trend in western physiognomy of focusing on negative signs and readings, of which there are far more than there are positive. It also underscores the likelihood that feminine physical characteristics will provide unfavorable

non facile hebetatur aut circumvenitur arte aliqua vel ingenio. vincentem per virtutem, studiosum, magnaninium, strennuum.

${ }^{446}$ Albertus, De animalibus. Kitchell, 95. Stadler, 47. misericordes, invidas, facile cedentes passionibus, laboris impatientes, amaras, subdolas et timidas.

${ }^{447}$ Albertus, De animalibus. Kitchell, 236. Stadler, 178. Significatur astutia et malicia dispositionis. Hoc enim est signum frigidi fleumatis habundantis supra formativam: et hie qnidem facile recipit forrnas et de facili movetur etiam a motore debili: et ex hoc causatur astutia feminina in rebus parvis et inutilibus et nocivis, et significat malam secundum Phytagoram feminarum dispositionem. 
readings. This negative reading is true not only of physical traits identified as belonging to women but in feminine traits belonging to men. An additional instance in the same chapter gives a more general description of feminine and masculine backs: feminine backs are narrow and "the lower part of the spine lies on wide buttocks and is surrounded by soft flesh." ${ }^{\prime 48}$ The binary is presented in his explanation that this is opposite of the "wide, solid" masculine back of males. ${ }^{449}$ Again, the feminine characteristics are negatives ones, shown in opposition to the positive masculine ones. Like most of the physiognomers before him, Albertus makes most feminine signs either negative in general or negative when found on a male, making it not just a male/female dichotomy, but often one of good and bad.

A second familiar kind of physiognomy is using a man's likeness to animals. Although the expected lists of readings organized and based upon these animal likenesses are replaced with the lists organized by members, this absence of animal likeness categories does not preclude Albertus from including discussions of animal likenesses in other ways in the first book. Indeed, there is an instance of animal physiognomy in Tract 2, chapter 3, when Albertus discusses the pupil. Albertus writes,

Further, wherever the orbs of the pupils are moderate they designate that the animals possessing them are strong. Serpents, hyenas, monkeys, uniones - that is shellfish [testudines] which have pearls - and foxes have

\footnotetext{
${ }^{448}$ Albertus, De animalibu. $s$ Kitchell, 239. Stadler, 181. Adhuc autem spinae pars inferior si latis iaceat natibus et molli carne circumdata, femininum est et effeminates ostendit.
}

${ }^{449}$ Albertus, De animalibus. Kitchell, 239. Stadler, 181. Amplius autem dorsum latum et solidum virile est. 
small pupils. The character of such beasts is indicated in a man whose

pupils are small. ${ }^{450}$

This physiognomic reading of the eyes, while it does fit the basic idea of discerning the character of a man from his physical likeness to animals, is not only a lone example, but also a very general one compiled from a long list of animals with small pupils.

There is also a series of mentions of animals in relation to man that Albertus attributes to Plato, though modern editors believe that he meant Polemon. ${ }^{451}$ First, in a discussion on the meanings of solid, blunt nostrils, Albertus notes,

Plato felt that such nostrils were given to well-born lions, humans, and dogs. This is because he saw such nostrils on well-born lions and dogs and he said that certain likeness exists between various animals and humans and that people imitate the habits of animals. He said that long, thin nostrils were proper to birds and that they bestow the habits of this animal, lightness and mobility, to those who have such nostrils. ${ }^{452}$

${ }^{450}$ Albertus, De animalibus. Kitchell, 99-100. Stadler, 52. Adhuc autem sicubi moderati sunt orbes pupillarum, fortia designant esse animalia quorum sunt. Serpentes autem et hyenae, symiae, uniones sive testndines quae margaritas habent, et vulpes pupillas liabent parvas; et talis animus bestiarum significatur in homine, cuius pupillae sunt parvae.

${ }^{451}$ See Kitchell and Resnick, footnote 854, p. 241.

${ }^{452}$ Albertus, De animalibus. Kitchell, 129-130. Stadler, 80. Tales enim nares Plato censuit dari leoninis hominibus et caninis generosis, eo quod in leonibus et canibus generosis tales nares videbat. Dicebat enim, quod quaecumque similitudo animalium aliquorum in hominibus est, quod et homines talium imitantur mores animalium: et quod nares longae et tenues avibus sunt propriae, et huiusmodi mores mobilitatis et levitatis dant hominibus qui tales nares habent. 
Again, Albertus is choosing to look at the features of general groups of animals, though this time one step removed through his citation of Plato.

While this instance is the longest and most involved, Albertus goes on to make brief mentions of Plato/Polemon's various findings involving corresponding physical traits and characters between man and animal. These citations and the animal information that they contain tend to follow the rest of the physiognomic information, appearing only after the bodily sign and its reading have been given. Thus, they appear more like asides or supporting information than stand-alone physiognomic signs and readings.

For instance, when discussing the physiognomy of the lips, Albertus tells us that "thin lips on a large mouth, when the upper lip swells out a bit over the lower one, as if it were superimposed on it, indicate a great-hearted and brave man. According to Plato, these lips recall the lion." ${ }^{453}$ In other words, Albertus gives us the physical sign (thin lips on a large mouth) and the reading (great-hearted and brave) before he mentions their relationship to the physical traits and character of a lion. This pattern continues with negative readings of other kinds of lips. Albertus writes that a mouth that is far too wide indicates voracity, harshness, impiety, and aggressiveness." ${ }^{, 454}$ It is only afterwards that he tells his reader, "The opening of such a mouth is attributed by Plato to beasts and

${ }^{453}$ Albertus, De animalibus. Kitchell, 133. Stadler, 83. Labia autem tenuia in ore maiori si superius labium aliquantulum exuberet super inferius, tamquam sit superpositum ei, magnanimum indicant et fortem. Secundurn enim Platonern haec ad leonem referuntur.

${ }^{454}$ Albertus, De animalibus. Kitchell, 133. Stadler, 83. Cum autem ultra modum dilatator, tamquam sit recisum et deductum, voracem indicat et immitem et impium et bellicosum. 
monsters of the sea."455 Similarly, the claim that that thick, rounded, turned-back lips mean a "foul, stupid, voracious person" is followed by the observation that "Plato attributes these traits to the pig." ${ }^{456}$ The only exception to the pattern is when Albertus notes that Plato calls "lips that protrude over the teeth and hang down a bit" a "canine mouth" before he gives the character reading of a "slanderer, wrathful, vociferous, and ready to inflict injury." ${ }^{, 457}$ Despite the change in order, the animal portion is actually less emphasized, only noting the physical similarity and not that of the characters.

The other chapter with a number of animal comparisons is on the posterior members. If the sides of the body are "hard and filled with flesh," they "indicate an unteachable person and, according to Plato, are comparable to those of a frog." ${ }^{458}$ In a similar manner Albertus notes that the lion relates to firm, hard hips and that a widowspeak hairline is equine. ${ }^{459}$ The final connection between animals and physiognomy is in the same chapter, but deals with the gait. Albertus writes,

${ }^{455}$ Albertus, De animalibus. Kitchell, 133. Stadler, 83. Talis enim oris rictus a Platone marinis datur beluis et monstris.

${ }^{456}$ Albertus, De animalibus. Kitchell, 133. Stadler, 83. Quando autem os longe prominet et est rotundurn cum spissitudine labiorum et aliquantulum retortum, ac si sit repandum in labii exiremitate, immundum, stuitum, voracem et forte futurum epilenticum ostendit. Haec enim porco Plato attribuit.

${ }^{457}$ Albertus, De animalibus. Kitchell, 133. Stadler, 83. Quando vero eminent labia super dentes aliquantulum dependentia, quod os caninum Plato vocat, maledicum, iracundum, clamosum et ad inferendam iniuriam promptum declarat.

${ }^{458}$ Albertus, De animalibus. Kitchell, 239. Stadler, 181. Quae autem referta sunt carnibus et dura, indocilem hominem ostendunt: haec enim ad ranas secundum Platonem referuntur.

${ }^{459}$ Albertus, De animalibus. Kitchell, 239. 
But when movements of the feet and hands agree well with those of the body as a whole, and when they make their way with a slight, becoming tilt of the head and neck, this indicates a great-hearted, brave person, this being the gait of the lion, according to Plato. ${ }^{460}$

While there are many other mentions of animals in following books, they are either focused on animals specifically, which takes up the majority of the rest of the books, or are occasionally offered as subjects for comparative anatomy with humans. This comparison begins in Book I itself. For instance, in discussing the spleen and liver, Albertus writes, "A human spleen is long and narrow, like that of a pig. The human liver is round, like the bull's in shape, but is not as large." $" 461$

A third additional form of physiognomy in De animalibus is geographical. Specifically, Albertus ties together climes and physiognomy overtly. In the chapter on the skin, Albertus cites Polemon (Phylemon) and then introduces the climes. He writes, The physiognomy of the skin is assigned by the wise man Phylemon, who says that a soft, dark color indicates a clever, timid person and refers to those who live in the first four climata. A fair, ruby-red color, however, indicates brave, spirited people, and this is especially a trait of those living in Germany and of inhabitants of the sixth and seventh climata. An

\footnotetext{
${ }^{460}$ Albertus, De animalibus. Kitchell, 241. Stadler, 183. Cum autem pedum et manuum motus cum totius corporis motibus consentiunt, et cum bene et moderate ac tranquille inferuntur cum inclinatione aliqua capitis decenti et cervicis, indicat hominem magnanimum et fortem; tails enim est incessus leonis, ut dicit Plato.

${ }^{461}$ Albertus, De animalibus. Kitchell, 279. Stadler, 218. Splen autem hominis est strictus et longus et similis in exterioribus spleni porci. Epar autem hominis est rotundum simile in figura epati tauri, licet non sit tantum in quantitate.
} 
exceptionally fair color, along with pallor, indicates a defect in power from excessive prevalence of phlegm. A red color whose redness is not clear but is dense announces a person forever planning deceits. If the color is deformed with pallor, it signifies one who is weakened by the love of women or is timid. This is provided that the cause of the color is not due to an illness, but is natural. ${ }^{462}$

This passage is long enough to make it clear that Albertus is linking climes to physical traits, i.e. the lower climes yield darker skin and the upper climes lighter skin. As in his geographical work, Albertus makes evident that those living in the very far north, those of "exceptionally fair color" are less healthy. Nevertheless, the physiognomic readings only come from a few specifics of coloring and are not assigned to a clime specifically, i.e. dense redness reveals deceitful planning.

Given Albertus's interest in geography and his authorship of De natura locorum, his exploration of the links between climes and physiognomy is not surprising. A bit more unusual, however, is his inclusion in De animalibus of some of Polemon's style of geographical case studies. These were largely ignored after the Islamic medicalization of

${ }^{462}$ Albertus, De animalibus. Kitchell, 284-285. Albertus locates the first four climes between the 0 and 36 degrees of latitude. The sixth and seventh climes he places from 41 to 48 degrees latitude. See chapter 3 of this work for more details. Stadler, 222. Physonomia autem huius assigntur a Phylernone sapiente. qui dicit, quod color niger lenis versitum indicat et imbecillem et ao refertur ad habitatores qui habitant quatuor prima climata. Color autem albus rubeus, fortes et aninosos ostendit: et hie est habitantium in Germania praecipue et habitatorum sexti et septimi climatum. Color autem vehementer dbus cum pallore defectum significat virtutis ex nimia victoria flamatis. Color autem rubicundus non clarae rubedinis sed spissae, omni tempore dolis studentem hominem declarat. Color autem pallore deformatus, effeminatum amore feminarum aut imbecilem eltimi dum significat, si non ab aegritudine sit causa coloris, sed a natura. 
physiognomy, but Albertus does not follow those medicalized examples. Instead he refers to a few of what he calls Polemon's examples, but with the geographical information removed.

The first is in his discussion of the eyes and droplets (guttulae) of color in the iris. Here Albertus mentions a detailed, specific physical description:

When, however, the droplets are violently red, and are not at all round, but some of them may tend to be squarish, some pale and others bright, and there are circles surrounding the outside of the pupils, and if the eyes be bloody and large, and the black of the pupil moves as the eyelid moves, they indicate a character that goes beyond every habit of the beast's.

Whatever sort of unspeakable acts may be imagined can be performed by those with eyes such as these. They will stop at neither domestic blood nor at any other impiety. Thus Palemon made note of such a man in his own day who, he said, was most wicked. ${ }^{463}$

In this way, Albertus includes both the depth of physical detail in Polemon and the elaborate reading based upon the signs, but without stating where that man is from. Also, while in the style and some of the basic sign elements of Polemon's geographic

${ }^{463}$ Albertus, De animalibus. Kitchell, 101-102. Stadler, 53-54. Ubi autem guttulae vehementer rubent, et non omnino rotundae, sed aliquae earum tendant ad quadraturam, et quaedam sint etiam pallidae et quaedam glaucae, et circuli qui forinsecus ambiunt pupillas, sint sanguinolenti, et sint magni occuli, et nitor pupillae moveatur, ut movetur palpebra, significabunt huiusmodi occuli animum qui omnem excedit morem ferarum: quidquid enim infandorum cogitari potest, huiusmodi occulis perpetrabile est: nec a domestico sanguine neque ab aliqua cessabunt impietate. Unde Palemon talem sui temporis hominem notavit, quern sceleratissimum esse dixit. 
examples, this description does not match any particular case study in Polemon's work, at least in those versions still extant. However, a few of the phrases, including domestico sanguine, can be found in the Physiognomia of the Anonymous Latinus. ${ }^{464}$ Another possible translation of this phrase is domestic murder, or, in todays terms, domestic violence.

The same chapter contains a second example of Albertus's retelling of a specific physiognomic reading or case study and then attributing it to Polemon. It reads, Palemon, however, described one particularly harmful example of such eyes. He did not assign it a name, but he did add to it many indications from the body, and he is understood to have spoken about a certain Favorinus. For he said that this man had a taut forehead, soft cheeks, a slack mouth, thin neck, thick legs, flat feet with thick flesh, a feminine voice and diction, lacked energy in every limb and joint, was voluptuous and dissolute, and, out of an inability to endure his desires, he is said to have both performed and to have endured at the hands of others all things, even those against nature. He says, moreover, that he was a slanderer, and was rash, eager for evil deeds. He was said to sell deadly poison in private. $^{465}$

${ }^{464}$ Anonymous Latinus, Physignomia, 574. Latin: Nam quicquid infandum cogitari vel non cogitari potest, huiusmodi oculis perpetrabile est: non a domestico sanguine, non ab impietate ulla, non ab iniuria hominum vel deorum hi oculi abstinebunt.

${ }^{465}$ Albertus, De animalibus. Kitchell, 105-106. Kitchell and Resnick point out in a footnote that Flavorinus was an intellectual who prospered under Hadrian until Polemon took his place. Stadler, 57. Palernon tamen quemdam talium occulorum multum noxium 
This example is similar to the first in its elimination of geographical details and failure to match with a single extant Polemon example, but it, like the first example, matches Polemon's style in its effusive list of both physical characteristics and negative readings of Flavorinus's character.

\section{Albertus and Physiognomic Authorities}

It is in the theoretical physiognomy of the second chapter of the second tract that Albertus tells the famous story with which I began the first chapter of this work, the story of Polemon's physiognomic reading of Hippocrates, though he calls Polemon "Phylemon" and attributes the story to Aristotle. It is a story that Albertus tells in order to illustrate the idea that physiognomy deals with inclinations and not necessity, inclinations that, at least in Christianity, stem from original sin. This sin can be largely, if not entirely, resisted by the supervision of the soul over the body through will and with the grace of God. However, the sources that Albertus must grapple with are almost without exception, not Christian, at least in origin. In his evaluation of physiognomy, Albertus cites a number of expected and important authors other than Polemon, a list that includes Aristotle, Avicenna, Constantine the African, and Loxus. ${ }^{466}$

descripsit: sed ei nomen non posuit, sed multa corporis sui indicia adiunxit, ita quod de quodam Favorino intelligitur dixisse. Dixit enim hunc habuisse tensam frontem, genas molles, os lapsum, cervicem tenuem, crassa crura, pedes planos tamquam congestis pulpis, vocem femineam, verba muliebria, membra et omnes artus sine vigore, luxuriosum et dissolutum: impatientia libidinum turpia fecisse omnia et passum esse ab aliis etiam contra naturam. Praeterea dicit eum fuisse maledicum, temerarium et maleficiis studentem. Dicebatur enim venenum letiferum clanculo vendere.

${ }^{466}$ Albertus, De animalibus. Kitchell, 94. Stadler, 46. Sequentes auctores magnos huius artis, Aristotelem videlicet et Avicennam, Constantinum et ipsum, quem commendat 
Albertus's use of Polemon as an authority is a bit uneven, as is attested to by his rather loose citations of his case studies and the many different alternate spellings within the same work, namely Palemon, Phylemon, and Plato. However Albertus appears to be rather impressed by Loxus, the physiognomer of whom we only get glimpses from the Anonymus Latinus. ${ }^{467}$ Indeed, from Loxus's prominence in De animalibus Albertus makes it appear as if he had the physiognomic work of Loxus either at his fingertips or in his memory.

These frequent mentions of Loxus appear almost every time Albertus sees the need to cite a physiognomic authority. It is unsurprising that he cites Loxus for the theory specifically mentioned and attributed to him in the Physiognomia of the Anonymus Latinus, the assertion that the blood is the seat of the soul. In order to explain this idea without insulting any of his most important conflicting authorities, Albertus takes a conciliatory tack, saying that Loxus's assertion is not without merit because the blood is where the spirits are distilled into pneuma. ${ }^{468}$ After dealing with the major idea of Loxus's attested to by Anonyous Latinus, Albertus continues to cite him, but in unusual ways not traceable to Anonymous Latinus, such as on the physiognomy of the ears, saying, "When the ear lobes stick out and are very large, it is, according to Loxus, a

Aristoteles, Phylemonem, Loxum quoque et Palemonem declamatorern, qui de physonornya perfeetius ceteris tradiderunt.

${ }^{467}$ See chapter 2 of this dissertation.

${ }^{468}$ Albertus, De animalibus. Kitchell, 94. Stadler, 47. Spiritus enim qui vehicula sunt virtutum eius, ex sanguinis generantur humore. 
sign of dullness, talkativeness, and imprudence. ${ }^{\$ 469}$ Loxus appears again as an authority on the physiognomy of the lips. Albertus tell us, "Loxus says that if a person's lips give rise to violent expressions, they indicate insanity and stupidity." ${ }^{470}$ The trend only continues, with Loxus cited again on the lower legs. Albertus writes, "Moreover, lower legs that are bristling with dense hair are, according to Loxus, indications of an ignorant and fierce person."${ }^{.471}$

This array of citations of Loxus alone is buttressed by Albertus's tendency to cite him with Polemon as a pair in agreement, thus elevating him as an authority for a great number of the physiognomic assertions in De animalibus. For instance, when Albertus repeats the familiar argument that the eyes provide the most important signs for physiognomers, he cites both "Palemon" and Loxus when he writes, "The entire perfection of physiognomy exists in the eyes." ${ }^{472}$ Loxus is mentioned with "Philemon" or "Palemon" again as a corroborating authority on the physiognomy of the nostrils, ${ }^{473}$ the physiognomy of the breath, ${ }^{474}$ and the physiognomy of the members in general in a

${ }^{469}$ Albertus, De animalibus. Kitchell, 113. Stadler, 64. Cum autem fuerint auriculae prominentes et valde magnae, significatur stoliditas, et garrulitas, et imprudentia, ut dicit Loxus.

${ }^{470}$ Albertus, De animalibus. Kitchell, 133. Stadler, 83. Dicit enim Loxus: Si cui labia truces vultus exagitant, insaniam et stultitiam indicabunt.

${ }^{471}$ Albertus, De animalibus. Kitchell, 241. Stadler, 182. Amplius autem crura densis capillis obsita secundum Loxum indocilem et ferum hominem indicabunt.

${ }^{472}$ Albertus, De animalibus. Kitchell, 99. Stadler, 51. In occulis autem principaliter consistit omnis perfectio physonomiae.

${ }^{473}$ Albertus, De animalibus. Kitchell, 130.

${ }^{474}$ Albertus, De animalibus. Kitchell, 256. 
chapter on the posterior members. ${ }^{475}$ In the last example on the general physiognomy of visible members, Albertus notes that Loxus and Polemon "have explored the matter more thoroughly than the others.. ${ }^{476}$ To speculate on whether Albertus had a manuscript of a no-longer-extant work by Loxus or a Polemon manuscript misattributed to Loxus is not likely to bear fruit, but it is clear from Albertus's writing which authors he thinks are the most important physiognomic authorities and that Loxus is one of them.

Although he tends to pair Loxus and Polemon, Albertus does once mention Loxus and "Aristotle writing to Alexander" as the authorities on the bodily members. ${ }^{477}$ This occurs in Albertus's discussion of the breasts. While it is a brief mention, it does point to a likelihood that Albertus was drawing upon the Pseudo-Aristotelian Secretum Secretorum. However, Albertus only refers to Loxus and Aristotle as authorities on the physiognomy of the breasts and offers no signs or readings, only the breasts's anatomy and physiology.

\section{Albertus's Physiognomy and Theology}

Albertus, then, accepted a largely medicalized form of physiognomy, though not without frequent snippets of animal, masculine-feminine binary, or geographical physiognomy. He also clearly relied upon Polemon and Loxus most frequently as his

${ }^{475}$ Albertus, De animalibus. Kitchell, 238.

${ }^{476}$ Albertus, De animalibus. Kitchell, 238. Stadler, 180. Horum autem membrorum physonomya accipitur a Palemone et Loxo Philosopbis, qui subtilius eam quam alii sunt rimati.

${ }^{477}$ Albertus, De animalibus. Kitchell, 214. Stadler, 158. Horum autern membrorum physonomya a Loxo tradita est philosopbo et ab Aristotele ad Alexandrum scribente. 
authoritative sources. What, though, does he have to say about the ways in which physiognomy fits into his medieval world view, a view constructed within the milieu of Parisian university life and his role as a Dominican administrator and leader?

Like most high medieval thinkers, Albertus was convinced that the world makes sense. The natural world was a second book written by God and legible to those who knew how to read it. Given this underlying assumption, physiognomy made sense because it fit into an intellectual structure based upon the contemporary knowledge of man and his natural world. It was accepted because the connection of the soul and the body also made sense. Many explanations of this connection came from the medicalization of physiognomy and its integration with ancient Greek humoral medicine. However, the ways in which it fit with theology and related ideas were equally important for Albertus.

Albertus had to make it clear that the scientia of physiognomy is one of reading signs of inclinations and was not determinism in order to underscore that Christianity allowed, or even encouraged it. This is seen in the previously mentioned statement at the beginning of the second tract of the first book, just as he introduces the importance of and justifications for physiognomy. Albertus states, "The natural inclinations of human dispositions and their lifestyles can be described based on indications arising from their natural members."478 However, Albertus leaves the assurance there for his reader without further explanation. In part, this is because it is work of commentary on Aristotle's zoology. Nevertheless, Albertus cannot help the very occasional religious reference,

${ }^{478}$ Albertus, De animalibus. Kitchell, 93. Stadler, 46. Oportet etiam de moribus hominum mentionem facere, secundum quod a naturalium membrorum signis declarari possunt naturales hominum inclinationes affectuum et regimina vitae. 
noting that "we must marvel at the wisdom" of the maker, before listing the details and intricacies of the human spine that show this wisdom. ${ }^{479}$ This wise maker or creator is much more clearly Christian than, for instance, the comparison of the heart in the body to the prime mover in the universe mentioned earlier in the chapter.

Less ostensible than the mentions of inclination and the creator to theology are the implications of passivity, activity, and receptivity in the human body and soul.

Nevertheless, they are of equal or perhaps even more theological importance to physiognomy. In Aristotelian physics the most perfect is also immutable, with the ultimate example being the Unmoved Mover, or the Christian God who is not effected by anything but affects everything. Man, however, like all animals, has mutable, receptive senses. Touch is the sense that all animals share, along with some moist member for receiving it, a uniform member that is "passive and receptive." 480 Other members of the human body can "only receive sensation via the passions" of the moist sensory members. $^{481}$

The theological importance of this comes from the implications of passivity, activity, and receptivity vis-à-vis the soul and original sin, which corrupts man, both in the moral sense and in the sense of change. The relationship between these concepts and

${ }^{479}$ Albertus, De animalibus. Kitchell, 147. Ammiranda autem est sapientia conditoris, qui naturae opus fecit esse opus intelligentiae, et ideo dorsum ad rotunditatem formavit, eo quod haec figura minus suscipit nocumenta.

${ }^{480}$ Albertus, De animalibus. Kitchell, 70. Stadler, 25. Passivum autem et receptivum in animalibus est membrum simile.

${ }^{481}$ Albertus, De animalibus. Kitchell, 70. Stadler, 25. Et dissimilia non patiuntur nisi per passiones similium. 
physiognomy is illustrated in the role of emotions. Indeed, emotions are key to this discussion. Whether as a sign that is read or a tendency discovered by a reading, emotions clearly manifest the actual connection between body and soul. These are specifically natural emotions, those innate emotions associated with the sensitive soul. The sensitive soul is in the middle of the tripartite hierarchy, between the vegetative and intellective souls, and is shared by humans and animals. Also shared with animals are natural emotions like wrath and fear, which stem from the sensitive soul.

Other terms for these emotions are accidents of the soul or passions. The term accidents is worth emphasizing because it implies that, although the natural emotions have no effect on the soul's essence, they can change certain of its "superficial" characteristics. It is also important to note that passio in Latin has both an emotional meaning and a passive use. ${ }^{482}$ Passions are often inflicted upon some part of the body or soul of a person. Because they are passively suffered or undergone, the nature of these emotions is generally harmful. The connection between soul and body wrought by natural emotions can be seen in Albertus's physiognomic discussion.

Emotions are also largely negative. The church fathers added to the negative connotation and made a number of emotions sins. This leads to the idea of the seven cardinal sins as epitomized in such emotional states as wrath, lust, and envy. The idea of wrath (ira) as a sin further emphasizes the desirability of controlling the passions of the sensitive, or natural soul, which is associated more with the bodily emotions and the physical world than with the intellectual soul that provides a connection to the divine. The emotions that tie us to our bodies are thus to be avoided or at least repressed because

${ }^{482}$ The root for passio is patior. 
they can prevent our attaining the highest good, in contemplating God. Barbara Rosenwein points out that sin was "tied to the flesh. When emotions became sins, they ceased to be cognitive appraisals ... and became, instead, part of man's corrupt and fallible nature. .... In like fashion, virtue was now sometimes conceptualized as contrary to emotion. ${ }^{483}$ Albertus is the product of this tradition, and it is reflected in his views of natural emotions, the passions of the sensible soul, as will be seen with ira (wrath) in De animalibus. However, De animalibus is not an overtly theological condemnation of emotions or a sermon against sin. Instead it uses emotions and emotional language in concert with humoral theory.

The importance of emotions is made clear in Albertus's discussion of complexions. In a chapter on the heart he notes,

Again, bodily strength also signifies a balanced complexion and weakness signifies badness of the same complexion. The reason for this is that the substance of natural heat, spirit, and blood is most often in the heart, neither heated up nor full of vapors, but rather pure and shining. But violent, heated anger and a quarrelsome soul indicate that heat of an accidental nature is in it, to the extent that it sometimes causes some harm to the breathing.

When the thoughts tend to joy, as faithfulness and good hope do, it signifies strength of the heart and a balanced complexion. When, however, they tend to solitude and separation from others, they signify an

${ }^{483}$ Barbara Rosenwein, Emotional Communities in the Early Middle Ages (Ithaca, NY: Cornell University Press, 2006), 49. 
excess of heat. Those that tend to fear and sadness signify an excess of coldness in it. ${ }^{484}$

Despite the mechanical nature of this evaluation, it is possible to see in this passage the relationship between the humors and emotions. Anger is symptomatic of too much accidental heat, fear means too little, while joy, faithfulness, and hope are signs of the correct amount. The same passage also hints at Albertus's discussions of the relationship between soul and body: a soul can be made "quarrelsome" by accidental heat.

Taking the example of anger, the emotion appears again and again in Albertus's physiognomy. For instance, if eyes are small, trembling, not bright, and dark, they "bespeak ... anger." 485 If eyes are watery it can mean the owner is "wrathful and prone to lust." ${ }^{486}$ If eyes "do not move and are, in addition, pale or reddish, with dryness, it is

${ }^{484}$ Albertus Magnus, De animalibus, 270. Stadler, 209-210. Aut etiam fortitudo corporis cordis significat aequalitatem complexionis, et debilitas significat malitiam complexionis eiusdem: et huius causa est, quia substantia caloris naturalis et spiritus et sanguinis plurima est in corde nec inflammata nec fumosa, sed potius splendida et pura: sed accidentalem calorem in ipso significant vehementia inflammationis in ira et rixa animae, ita quodquandoque perducit usque ad nocumentum aliquod anhelitus.

Meditationes vero, quoniam quae declinant ad gaudium, sicut fiducia et bona spes, significant cordis fortitudinem et aequalitatem complexionis. Meditationes autem quae declinant ad solitudinem et seiunctiones ah aliis, significant excessum in calore. Quae autem declinant ad timorem et tristitiam, significant excessum in frigiditate ipsius.

${ }^{485}$ Albertus Magnus, De animalibus, 101. Stadler, 53. Si autem nigri sunt cum hoc, magis sunt iracundi, quam insaniam dicant.

${ }^{486}$ Albertus Magnus, 102. Stadler, 54. Iracundiores tamen et iuxta venerem proniores sunt. 
certain that daily rages and furies (iras et furias) threaten such ones. ${ }^{247}$ Of all the wrathful eyes, the worst are those from his Polemon example, "which possess varied coloration so that the variegation is discrete, and which have present a small number of red droplets. ... [If] the droplets are violently red, and are not at all round, but some of them may tend to be squarish, some pale and others bright, and there are circles surrounding the outside of the pupils." ${ }^{, 48}$ These eyes are carefully described because they indicate a natural character of the worst sort, one that "goes beyond every habit of the beasts." ${ }^{489}$ The redder the droplets are, "the more they signify wrath, harmfulness, and adultery." ${ }^{490}$

Wrath can also be part of a natural character that is less overtly negative and more nuanced. Such is the case with eyes that "are medium-sized, moist, and crystal clear."491 While such eyes signify "a wrathful one, given to wine, a boaster who is desirous of glory

${ }^{487}$ Albertus Magnus, De animalibus, 106. Stadler, 58. Si autem immobiles sunt occuli, et cum hoc pallidi vel rubicundi sint cum siccitate, certum est hiis iras et furias imminere diuturuas.

${ }^{488}$ Albertus Magnus, De animalibus, 101-102. Stadler, 53. Varietatem autem in se habentes, ita quod ipsa varietas discreta est, et quando guttulae rubentes sunt aliquantulum. . . guttulae veheinenter rubent, et non omnino rotundae, sed aliquae earum tendant ad quadraturam, et quaedam sint etiam pallidae et quaedam glaucae, et circuli qui forinsecus ambiunt pupillas.

${ }^{489}$ Albertus Magnus, De animalibus ,102. Stadler, 53. Significabunt huiusmodi occuli animum qui omnem excedit morem ferarum.

${ }^{490}$ Albertus Magnus, De animalibus, 103. Stadler, 55. Si autem sint rnoderatae magnitudinis et humidi atque perlucidi.

${ }^{491}$ Albertus Magnus, De animalibus, 103. Stadler, 55. Aliquando etiam indicant iracundum et vino deditum et iactantem sui et cupidum gloriae ultra condicionem humanam. 
beyond the human condition" the opposite side of the coin is that he is also a man capable of superior things, such as Alexander the Great. ${ }^{492}$

While the eyes are the most important diagnostic tool for physiognomers, Albertus's physiognomy supports a diagnosis of a wrathful natural inclination from other parts of the head and face, which are closer to the eyes than the rest of the body. If the back of the head is "valleyed, almost as if it is concave" its owner is "given to anger (iracudiae) and contrivance." ${ }^{493}$ A round forehead denotes wrath, even more so if it "has a crease in the middle, as if it were bound." forehead" the person is not just wrathful, but spirited and stupid as well. ${ }^{495}$ Albertus does acknowledge gradations of anger, such that the less the better. He writes that a "fairly long" chin signifies a "less wrathful and troubled character," at least when it does not "announce piety." ${ }^{496}$ Other wrathful signs near the eyes include a too-long, pig-like neck, ${ }^{497}$ and a "dusky or ashen color" that accompanies paleness. ${ }^{498}$ Even worse, if the

${ }^{492}$ Albertus Magnus, De animalibus, 103. Stadler, 55. Et tarium occulorum putatur Alexander Magnus fuisse.

${ }^{493}$ My translation from Stadler's Latin edition, 49. Caput autem quod in posteriori parte est vallicosum, quasi sit concavum, dolis et iracundiae est deditum.

${ }^{494}$ Albertus Magnus, De animalibus, 97. Stadler, 49. Quibus autem contrabitur in medio, tamquam sit obstricta, sunt iracundi.

${ }^{495}$ Albertus Magnus, De animalibus, 97. Stadler, 50. Pili autem superciliorum si sunt refracti versus frontem, dicunt animosum, stultum et iracundum.

${ }^{496}$ Albertus Magnus, De animalibus, 140. Stadler, 89. Mentum enim cum prolixius fuerit, minus iracundum et minus perturbaturn demonstrat animum. Aliquando etiam pietatem declarat.

${ }^{497}$ Albertus Magnus, De animalibus. Kitchell, 210. 
"veins of the temples and neck are ruby red" along with bloodshot eyes, it indicates "one so wrathful as to be insane." ${ }^{499}$

Understood in this way, as largely negative physiognomic signs and readings, emotions become a path to a version of solving the mind/body problem for Albertus, the problem of how physical body parts can make an impression on the incorporeal soul and vice versa. Emotions become the glue that keeps the underlying necessities of physiognomy, the connections between body and soul, in place. In this way, the only thing that is occult in Albertus's physiognomy in the sense of being hidden is that he leaves his reader to tease out this vital role that emotions play rather than bluntly stating it.

Emotions are also a symptom of the theological necessity of not allowing physiognomy to be capable of determinism. If physiognomy detects tendencies, it becomes theologically safe. Indeed, if the readings show the tendencies toward which kind of sin a man holds, then it could even be a positive tool for shepherding souls, for helping prepare them for resisting specific temptations. For, if the natural passions are allowed to change the soul, if a human gives into natural inclinations, the consequences are dire. In choosing to make himself "subordinate to the world, discarding, as it were, the honor of his humanity," a person will take on the characteristics of the animal that

${ }^{498}$ Albertus Magnus, De animalibus. Kitchell, 285. Stadler, 222-223. Si autem fuscus color et cinereus pallorem occupat, loquacem significat et intemperatum et iracundum.

${ }^{499}$ Albertus Magnus, De animalibus, 285. Stadler, 223. Si autem venae tymporum et cervicis rubeae sunt et occuli sanguinei, ostendunt adeo iratum ac si sit insanus. 
most similarly mirrors the ruling emotion. ${ }^{500}$ For instance, someone who allows himself to be ruled by anger becomes like a dog, both in character and in form. Albertus's makes his acceptance of this point evident in one of his lengthy discussions that he attributes to "Plato" or Polemon. In this discussion he argues that unlike mastering the natural emotions, giving up power to them of your own free will is clearly visible in the body. If a man does this, "he takes on the characteristics of corruption and the soul does not restrain the body and, broken and bent to the body, it passes quickly through mental images (imaginationes) and passions and hastens the corruption of the body." ${ }^{, 501}$ At the most extreme the natural passions can destroy the body. This again emphasizes that the body is meant to be subordinate to the intellective soul.

In this way Albertus underlines how the natural emotions need to be constrained in order to prevent them from overrunning the intellect. Thus physiognomy can assist Albertus and his brethren in their efforts to identify and guide other souls in need of help in order to control their natures and return to contemplating God. In this way, Albertus Magnus's physiognomy fits nicely into the assumption that the natural world and man's place in it are subject to reason and therefore understandable. It also makes sense theologically because of its ability to provide a tool to those seeking to overcome the flesh through grace and will.

\footnotetext{
${ }^{500}$ Albertus Magnus, De animalibus. Kitchell, 1445. Stadler, 1353. Si aliquando aliquis hominum per electionem se mundo inferiorem fecerit, iam quasi honore humanitatis exutus,

${ }^{501}$ Albertus Magnus, De animalibus. Kitchell, 1445. Stadler, 1353. Si autem per electionem se corpori supposuerit cum accidentia corporis animam transmutent, tune accipit corruptionis proprietates, et tune etiam corpus non continet, et sic inflexa et fracta ad corpus festinat per ymaginationes et passiones et accelerat corporis corruptiones.
} 


\section{Physiognomy After Albertus and the Thirteenth Century}

European interest in physiognomy did not end with Albertus Magnus or in the thirteenth century. Instead, once Albertus, Michael Scotus, and other scholastic thinkers of great renown had integrated it into their works, it only grew in popularity, albeit the scientia was not best known through Albertus's De animalibus. At first, this popularity continued in the intellectual and university millieu. Within only a few years of Albertus's death, we see a phisiognomia Aristotelis on a Parisian book list composed between 1275 and $1286 .^{502}$ By 1405 we have evidence that physiognomy was taught in extraordinary lectures in Bologna. ${ }^{503}$ Physiognomy had reached a level of true acceptance as a scientia by the end of the thirteenth century that continued for centuries afterwards. The continuing popularity of physiognomy as scientia is shown in its acceptance by the likes of William of Spain and Jean Buridan. ${ }^{504}$ For such men, as for Albertus and his contemporaries, physiognomy was a demonstrative science, one that "was expected to provide rational explanation for every bodily sign." ${ }^{, 505}$

502 Joseph Ziegler, "Philosophy and Physicians on the Scientific Validity of Latin Physiognomy, 1200-1500," Early Science and Medicine 12 (2007): 292. Ziegler notes that it was "bound together with a commentum Alexandri super librum Metheororum. It encompasses 19 pecias and is valued at nine pence."

${ }^{503}$ Ziegler, "Philosophy and Physicians," 292. By 1463 the University of Freiburg also required lectures on Aristotle's Physiognomy to continue from bachelors to masters of art.

${ }^{504}$ Ziegler, "Philosophy and Physicians," 285. He also lists William of Mirica and academic physicians (Rolandus Scriptor, Michele Savonarola, Bartolomeo della Rocca [Cocles]).

${ }^{505}$ Ziegler, "Philosophy and Physicians," 285. 
However, just as scholasticism began to be questioned in earnest, so did physiognomy. Scholarship has shown that in medieval intellectual circles, one of the problems of physiognmy may perhpas be simply distilled into one of logic. ${ }^{506}$ Indeed, the demonstrability of physiognomy is questioned by the likes of Buridan, despite his acceptance of it in general. Instead, fourteenth-century intellectuals began to prefer terms like "probabilitas." 507 This shift towards probability is part of showing that physiognomy, like medicine, is both a science and an art. Therefore, it is not a true $a$ posterori science, but "one that relies not on necessary premises but on ones which are plausible or true for the most part, and which depends on effects and not causes." ${ }^{\circ 08}$ This characterization of the kind of science which physiognomy is did almost nothing, however, to change the trajectory of its growing popularity beyond the intellectual world of the highest echelons of the universities. It is also worth noting that in one way this denial of logical certainty is nothing new, because Albertus and others were so careful to make it clear that they were talking about inclinations and not certainties. Nevertheless, the logic used to come to these conclusions by fourteenth-century and later thinkers was in some ways new and different.

Physiognomy had thoroughly permeated the late medieval intellectual world, despite debates about the nature of what kind of scientia it was. However, it also remained important in religious life beyond scholasticism. An example of this religious

\footnotetext{
${ }^{506}$ Ian Maclean, "The Logic of Physiognomy in the Late Renaissance," Early Science and Medicine 16 (2011): 275-295.

${ }^{507}$ Maclean, "Logic of Physiognomy," 276-277.

${ }^{508}$ Maclean, "Logic of Physiognomy,” 277.
} 
use of physiognomy is revealed in scholarship on Nikolaus Of Flüe (1417-1487). Taking the name Waldebruder, Nikolaus became a hermit at the age of 50 and settled at Ranfttal near his home of Flueili, where he became famous for fasting for twenty years. ${ }^{509}$ His life has three vitae and an unusual number of other written sources that take great pains to describe the "authentic face" of Nikolaus. ${ }^{510}$ In this case, the physical details of the saint are used in a form of physiognomy that "corresponds less with what one sees and more with what one expects to see." 511 In other words, physiognomic readings have the ability to be held up as sort of measuring stick by which to judge whether or not a saint was truly saintly, instead of "reading" a person and then seeing what the signs refer to in that person's nature. In many ways this is a continuation of, or at least a close parallel to, the physiognomic consciousness present in the Roman and early medieval world, though the resurgence of interest in physiognomy as a specific subject certainly may have played a role.

Instead of religious use, the bridge between physiognomy as a subject for university masters and students to one that permeated European culture as whole through at least the nineteenth century, seems to have been in large part the work of Giambattista Della Porta. A scholar renowned for his many scientific works, Della Porta published his

\footnotetext{
${ }^{509}$ Gabriela Signori, "Nikolaus Of Flüe ( $†$ 1487): Physiognomies Of A Late Medieval Ascetic," Church History and Religious Culture 86 (2006), 229-255.

${ }^{510}$ Signori, "Nikolaus Of Flüe,” 242.

${ }^{511}$ Signori, "Nikolaus Of Flüe," 254. Signori notes that this measuring ability of physiognomy was of particular value when the saintly deeds were ones of inaction (not eating) instead of ones of more active words and actions.
} 
De humana physiognomonia (1586), a work of physiognomy in four books. ${ }^{512}$ The first book includes a theoretical basis of physiognomy and preface that introduces the great physiognomers of antiquity, namely Polemon, Adamantius, and Aristotle. The second book introduces body parts and their signs, in the usual medicalized head-to-toe format. The first main point of interest is that classical animal comparisons have returned in a powerful way, including a number of illustrations showing different men's similitude to specific animals, such as donkeys, monkeys, and dogs. These animal-based physiognomic signs also include references to the traditional physiognomic masculine/feminine binary in, for example, the reference to the leopard or panther as the perfect example of feminine signs. The second main point of interest in the second book is that the eyes do not appear. This is because they are reserved for their own book, Book III, which contains 24 chapters on subjects like the pupil, color of the eyes, their movement, and more. The fourth book is a long list of the different sorts of men and the physical figures that they present to the world. These chapters begin with the physical characteristics of men who are just and unjust, good, bad, faithful and unfaithful, prudent and imprudent, clever, confused, good at remembering and forgetful, hearty, timid, immodest, strong, prideful and then continues on with almost thirty more chapters of more examples and signs.

Though Della Porta mentions "ancients" like Polemon, Aristotle, Plato, and Adamantius often, there are very few mentions of any medieval physiognomy, whether Islamic or Latin. Nevertheless, he is clearly the heir of their traditions. His De humana

${ }^{512}$ Giambattista Della Porta. De humana physiognomonia. Vico Equense: Giuseppe Cacchi, 1586. 
physiognomonia is the culmination of what Albertus, Michael Scotus, and other medieval thinkers began with their integration of physiognomy into Latin Christian thought. ${ }^{513}$ However, it is not just the content of Della Porta's treatise that is important, but also its widespread influence. This can be seen in the many editions that followed the original, including a Latin edition in Hanover in 1593 and a French version with a second edition printed in Paris by Jean and David Berthelin in 1660. This popularity of physiognomy is important because its spread into print culture and translation into the vernaculars allowed a much larger and very interested audience to access physiognomic texts and ideas. These included the ideas attributed to Albertus, even when not actually by Albertus, which circulated as the De secretis mulierum. This work appeared, for instance, in a Dutch pocket sized edition between 1640 and $1670 .^{514}$ By one estimation, by 1800 there were almost a half million copies of various physiognomic works published in Italy and 200,000 in France, many of these in the genre of books of secrets and many of those attributed to Albertus Magnus. ${ }^{515}$

This entry into popular print culture explains the proliferation of the use of physiognomy in other subjects. For instance, judges showed a great interest in physiognomy because of its possible uses in serious cases. Judging guilt in early modern Europe depended on a defendant's visible characteristics, i.e. features, complexion, and

${ }^{513}$ Maclean also points out that Della Porta is highly logical in his physiognomy: "Under these conditions, the predicate 'courageous' is a correct demonstrative inference from the sign 'having large extremities'." "Logic of Physiognomy," 282, footnote 16.

${ }^{514}$ Porter, Windows of the Soul, 12.

${ }^{515}$ Porter, Windows of the Soul, 97. 
gestures, as much as his or her verbal testimony. ${ }^{516}$ For example, Francesco Casoni (1500-1564) expressed some unusual caution about physiognomy, noting that only "general presumptions — and not specific ones—can be made." $" 17$ However, Casoni expressed a belief in the importance of a defendant's complexion, especially pallor. ${ }^{518}$ Most important, for Casoni, is what physiognomy could tell him about the intention of someone who committed a crime. In his De arte ac ratione (1561), he wrote, If someone were seen to have grown pale or to tremble or do things comparable to these and, after a short interval, kill someone, he is presumed to have done so intentionally. On the other hand, if after the crime, he is seen to grow pale or to flee, or to do similar things, these signs of this type indicate that something has happened but not intention, unless there are further signs, as has been stated in my De indiciis. ${ }^{519}$

This use of physiognomy is notable for both its new legal context and the fact that Casoni is not focused on permanent physiognomic signs, but on those more fleeting ones.

Vernacular literature is a second area where we see the influence of physiognomy in many examples by the end of the seventeenth century. For instance, the entremeses, or Spanish lyrical poetry, by Francisco de Quevedo (1580-1645) show the importance of

\footnotetext{
${ }^{516}$ John Jeffries Martin, "Francesco Casoni and the Rhetorical Forensics of the Body," Journal of Medieval and Early Modern Studies 45:1 (2015): 105.

${ }^{517}$ Martin, "Francesco Casoni," 106.

${ }^{518}$ Martin, "Francesco Casoni," 107.

519 Translation in Martin, "Francesco Casoni," 118. From the De arte ac ratione in criminum causis disserendi dialogus (Brescia, 1561), 21.
} 
physiognomy in his descriptions of viejas, or old women who cast spells. ${ }^{520}$ Not only is the negative physical representation of the viejas humorous, but also provides proof of their guilt and deserving punishment because of the reflection of their soul that physiognomy offers. ${ }^{521}$ Quevado was likely influenced by the work of Della Porta, as a description of the eyes of the viejas matches a description in De humana physiognomonia of crossed eyes that denote a deceptive, avaricious, irate, liar who is malicious in many things. $^{522}$

In the modern period, the proliferation of the influence of physiognomy on literature and physiognomic texts only continued to grow. This growth was particularly strong in the nineteenth century in response to the influential later works, particularly Physiognomische Fragmente zur Beförderung der Menschenkenntnis und Menschenliebe (1775-1778) by the Swiss author Johann Kaspar Lavater (1741-1801).

\section{Conclusion}

The physiognomy of Albertus Magnus represents the nexus between the physiognomy of the classical Mediterranean and that of early modern and modern Europe. It also represents a point at which physiognomy's milieu was almost entirely intellectual, largely because of language and the lack of translation into Latin or European vernaculars prior to the twelfth century. In this way, the thirteenth-century

\footnotetext{
${ }^{520}$ Jaime Hernandez Vargas, "Dos viejas celestinas y hechiceras en la lírica quevediana: fisonomía y retratos sociales como instrumentos punitivos," La Perinola 19 (2015): 161180.

${ }^{521}$ Hernandez Vargas, “Dos viejas,” 162.

${ }^{522}$ Hernandez Vargas, "Dos viejas,” 173.
} 
physiognomic sources taken as a whole are the key to connecting two Western historical periods that are saturated with physiognomy or at least physiognomic consciousness, among a wide swath of the literate or educated populations. A comparative study of physiognomy in the classical Mediterranean and the seventeenth through nineteenth centuries could prove fruitful in understanding both the similarities of physiognomy's appeal and in how modern ideas transformed the discipline at a popular level.

However, Albertus Magnus's physiognomy also provides us with a method of illuminating the ways in which medieval thinkers understood their world in the thirteenth century. The physiognomy that seems so ridiculous at first glance from a twenty-firstcentury point of view fit amazingly well with the underlying ideas of that earlier century. This fit, the fact that physiognomy made such sense to those thinkers we hold above others, serves as an important reminder not to read too much of our present modern or post-modern thinking into the Middle Ages. The saturation of physiognomy into Western culture as late as the early twentieth century may also remind us that we are not as progressive or "scientific," at least in the ways that those terms are popularly described, as we like to think. ${ }^{523}$

${ }^{523}$ An example that drove home for me that level of saturation was finding physiognomy in a work by the favorite author of my childhood, L.M. Montgomery, author of Anne of Green Gables. She wrote in chapter 3 of Kilmeny of the Orchard, "The other occupant of the wagon was a man between sixty-five and seventy, with iron-gray hair, a long, full, gray beard, a harsh-featured face, and deep-set hazel eyes under bushy, bristling brows. He was evidently tall, with a spare, ungainly figure, and stooping shoulders. His mouth was close-lipped and relentless, and did not look as if it had ever smiled. Indeed, the idea of smiling could not be connected with this man-it was utterly incongruous. Yet there was nothing repellent about his face; and there was something in it that compelled Eric's attention. 
He rather prided himself on being a student of physiognomy, and he felt quite sure that this man was no ordinary Lindsay farmer of the genial, garrulous type with which he was familiar." (London: LC Page and Co., 1910), 39-40. 


\section{BIBLIOGRAPHY}

\section{Primary:}

Adamantius, Physiognomy. See Swain.

Albertus Magnus. D. Alberti Magni, Ratisbonensis Episcopi, Ordinis Praedicatorum:

Opera Omnia. 9 vol. Ed. A. Borgnet. 1890-99.

----------. Albertus Magnus On Animals: A Medieval Summa Zoologica Kitchell, Kenneth F. Jr, and Irven Michael Resnick, trans and eds. 2 vols. Baltimore: The Johns Hopkins University Press, 1999.

---------. De animalibus. Hermann Stadler, ed. Münster: Aschendorfsche Verlagsbuchhandlung, 1916-1920.

---------. De natura locorum. See Tilmann.

Albertus and Thomas: Selected Writings. Trans. Ed. Intro. Simon Tugwell, O.P. and preface Leonard E. Boyle, O.P. New York: Paulist Press, 1988.

"The Almohad Creed." Trans. Madeleine Fletcher, in Medieval Iberia: Readings from Christian, Muslim, and Jewish Sources, ed. Olivia Remie Constable. Philadelphia: University of Pennsylvania Press, 1997.

André, Jaques, ed. Traité de Physiognomie: texte établi, traduit et commenté. Paris: Belles Lettres, 1991.

Anonymous Latinus. Physiognomy. See Swain.

Anselm of Canturbury. Complete Philosophical and Theological Treatises of Anselm of Canturbury. Trans. Jasper Hopkins and Herbert Richardson. Minneapolis: Arthur J. Banning Press, 2000.

Aristotle. De anima. See Barnes.

---------.. On the Parts of Animals. See Barnes.

History of Animals, In Ten Books. Trans. Richard Cresswell. London: Henry G. Bohn, 1862.

Athanasius. Vita Antonii. See Gregg.

Augustine of Hippo. On the Soul and its Origin, eds. Philip Schaff and Benjamin Breckinridge Warfield. Trans. Robert Ernest Wallis and Peter Holmes. 1887. 
Avicenna (Ibn Sina). De universalibus Medicae scientiae praeceptis (Book 1 of the Canon). Trans. Andrea Gratiolo. Venice, 1580.

. The Canon of Medicine of Avicenna, First Book. Trans. O. Cameron Gruner. New York: Augustus M. Kelly, 1970.

al-Shifa', Metaphysics II, ed. Anawati, Ibrahim Madkour, and Sa'id Zayed. Cairo: al-hay'a al-'amma lil-kitab, 1975.

Constantine the African. Constantini Africani Post Hippocratem Et Galenvm, Qvorum, Graec[a]e linguae doctus, posthabendi opera. Basil: Petrus, 1536.

Della Porta, Giambattista. De humana physiognomonia. Vico Equense: Giuseppe Cacchi, 1586.

Egeria, Travel Journal. See Maraval.

Einhard. Life of Charlemagne. See Grant.

Eriugena, Periphyseon (The Division of Nature), trans. I.P. Sheldon-Williams, revised by John J. O’Meara. Montreal: Éditions Bellarmin, 1987.

The Fihrist of al-Nadim, ed. trans. Bayard Dodge, 2 vols. New York: Columbia U Press, 1970.

Foerster, Richard, ed. Scriptores physiognomoici graeci et latini. 2 vols. New York: B.G. Press, 1893.

Galen. On the usefulness of the parts of the body: De usu partium. Trans. and intro Margaret Tallmadge May. 2 vol. Ithaca: Cornell University Press, 1968.

Gregory the Great. Regula Pastoralis. See John Leinenweber.

Hippocrates. Aphorisms. trans. Francis Adams. University of Adelaide, 2005.

---------. On Generation, On the Nature of the Child, and On the Nature of Women. In Hippocrates, vol. X, trans. Paul Potter, Harvard University Press, 2012.

Ibn ‘Arabī. Futūbāt. See Viguera Molíns.

Ibn Butlan. "Risala jami'a li-funun nafia fi shira' al-raqiq" [A Comprehensive Discourse on Knowledge Useful for the Purchase of Slaves], in Nawadir al-makhtufat ed. A. Harun, iv. Cairo, 1951.

Isidore of Seville. Etymologies. See Barney. 
John of Salisbury. Policraticus. Trans. and ed. Cary J. Nederman. Cambridge University Press, 1990.

Kraye, Jill, W.F. Ryan, and C.B. Schmitt, eds. Pseudo-Aristotle in the Middle Ages: The Theology and other texts. London: The Warburg Institute, 1986.

Lactantius. The Deaths of the Persecutors. See Ehrman.

Manzalaoui, M.A., ed. Secretum Secretorum: Nine English Versions. Vol. 1. Oxford: Oxford University Press/Early English Text Society, 1977.

Michael Scotus. Liber Phisionomie. Michael Wenssler: Basil, 1485.

-----Aristotle's De animalibus: Michael Scot's Arabic-Latin Translation, Part Three. Aafke M.I van Oppenraaij. Leiden: Brill, 1992.

Peter Lombard. The Sentences. See Silano.

Peter of Spain (later John XXI), Questiones super libro 'De Animalibus' Aristotelis: Critical Edition with Introduction. Ed. Francisca Navarro Sánchez. Ashgate, 2015.

Philip Chancellor. Philippi Cancellarii Parisiensis Summa de Bono. Nicolai Wicki, ed. Bern: Francke, 1985.

Plato. Timaeus. See Hamilton.

Pliny. Natural History, Volume I: Books 1-2. Trans. H. Rackham. Loeb Classical Library 330. Cambridge, MA: Harvard University Press, 1938.

Polemon, Physiognomy. See Swain.

Policratus. Quae pertineant ad religionem Preconsulum, prafidu, \& ordinariorum iudicunt; \& quatenus Xenia protendi liceat; \& de Cicerone, Bernardo, Martino, Gaudfrido Carnotensi. 1595.

Ptolemy. Geography. See Berggren.

Rhazes (al-Rāzī). Spiritual Physick. Trans. Arthur J. Arburry. London: John Murray, 1950.

Roger Bacon. Opus Tertium. In Opera Quaedam Hactenus Inedita, vol. 1, ed. J.S. Brewer. London: Longman, Green Longman and Roberts, 1859. 
The Secret of Secrets (Secreta Secretorum): A Modern Translation, with Introduction of The Governance of Princes. Lin Kerns, trans. Lewiston, NY: Edwin Mellen Press, 2008.

Suger of St. Denis, Abbot Suger: On the Abbey Church of St.-Denis and Its Art Treasures, trans. and intro. Erwin Panofsky. Princeton, NJ: Princeton University Press, 1979.

Sulpicius, The Life of Saint Martin. See Stouck

Vicent of Beauvais. Speculi Maioris. Venice, 1591.

William of Conches. A Dialogue on Natural Philosophy (Dragmaticon Philosophiae), Italo Ronca and Matthew Curr trans., University Notre Dame Press, 1997.

\section{Secondary:}

Agrimi, Jole. Ingeniosa Scientia Nature: Studi sulla fisiognomica medievale. Firenze: Sismel Edizioni del Galluzzo, 2002.

Alvar Nuño, Antón. "Ocular Pathologies and the Evil Eye in the Early Roman Principate." Numen, vol. 59 (2012): 295-321.

de Asua, Miguel. "Peter of Spain, Albert the Great and the Questiones de Animalibus." Physis, Volume 34, Issue 1-2, (1997): 1-30.

Al-Azmeh, Aziz. "Barbarians in Arab Eyes," Past \& Present, 134 (Feb., 1992): 3-18.

Bacci, Michelle. The Many Faces of Christ: Portraying the Holy in the East and West, 300 to 1300. London: Reaktion Books, 2014.

J. Lennart Berggren and Alexander Jones, eds. Ptolemy's Geography: An Annotated Translation of the Theoretical Chapters. Princeton, NJ: Princeton University Press, 2000.

Barney, Stephen A., W. J. Lewis, J. A. Bach, and Oliver Berghof, trans. and intro. Etymologies. Cambridge University Press, 2006.

Barns, Jonathan. The Complete Works of Aristotle, vol. I, ed. Jonathan Barnes. Princeton University Press, 1984.

Bertolacci, Amos. “Avicenna's and Averroes's Interpretations and their Influence in Albertus Magnus. In A Companion to the Latin Medieval Commentaries on 
Aristotle's Metaphysics, Companions to the Christian Tradition vol 43, Gabriele Galluzzo and Fabrizio Amerini, eds. Leiden: Brill, 2013.

Bieniak, Magdalena. The Soul-Body Problem at Paris, ca. 1200-1250. Leuven University Press, 2010.

Bos, A.P. The Soul and Its Instrumental Body: A Reinterpretation of Aristotle's Philosophy of Living Nature. Leiden: Brill, 2003.

Bossy, Michel-André. "Medieval Debates of Body and Soul," Comparative Literature, vol 28,no 2 (Spring 1976), 144-163.

Brink, Laurie. "Picturing Paul: The Good General Addressing His Troops," in Bible Today (2007).

Bullough, Vern L. Universities, Medicine and Science in the Medieval West. Aldershot, England: Ashgate Variorum, 2004.

Burckhardt, Jacob. The Civilization of the Renaissance in Italy. S.G.C. Middlemore, trans. London: S. Sonnenschein, 1904.

Burnett, Charles F. Arabic into Latin in the Middle Ages: the Translators and Their Intellectual and Social Context. Farnham, England: Ashgate, 2009.

Burns, E. Jane and Peggy McCracken, eds. From Beasts to Souls: Gender and Embodiment in Medieval Europe. Notre Dame, IN: University of Notre Dame Press, 2013.

Caston, Victor. “Aristotle's Two Intellects: A Modest Proposal," Phronesis, 44, no. 3 (Aug., 1999): 199-227.

Charles Burnett and Danielle Jacquart, Constantine the African and 'Ali Ibn al-'Abbas alMagusi: The Pantegni and Related Texts. Leiden: Brill, 1994.

Colish, Marcia L. Peter Lombard, 2 vols. Leiden: E.J. Brill, 1994.

Collins, David J. "Albertus Magnus or Magus? Natural Philosophy, and Religious Reform in the Late Middle Ages." Renaissance Quarterly 2010 (1): 1-44.

Corner, George W. Anatomical Texts of the Earlier Middle Ages: A Study in the Transmission of Culture, With a Revised Latin Text of Anatomia Cophonis and Translations of Four Texts. Washington D.C.: Carnegie Institution, 1927.

Davidson, Herbert A. Alfarabi, Avicenna, and Averroes on Intellect : Their Cosmologies, Theories of the Active Intellect, and Theories of Human Intellect. Oxford: Oxford University Press, 1992. 
Davies, Brian and Brian Leftow. The Cambridge Companion to Anselm. Cambridge University Press, 2004.

Druart, Thérèse-Anne. "Al-Razi's Conception of the Soul: Psychological Background to his Ethics." Medieval Philosophy and Theology 5 (1996): 245-263.

Dyck, Andrew R. A Commentary on Cicero: De Officiis. University of Michigan Press, 1996.

Ehrman, Bart D. and Andrew S. Jacobs. Christianity in Late Antiquity: 300-450 C.E. Oxford University Press, 2004.

El-Bizri, Nader. “Avicenna and Essentialism.” The Review of Metaphysics, 54, no. 4 (Jun., 2001): 753-778.

Evans, Elizabeth C. "Physiognomics in the Roman Empire." The Classical Journal 45, no. 6 (1950): 277-282.

Feldman, Louis H. "Philo's View of Moses' Birth and Upbringing." Catholic Biblical Quarterly 64 (2002).

Fletcher, Madeleine.“The Almohad Tawhīd: Theology Which Relies on Logic.”

Numen 38 (1991), 110-127.

Fontaine, Resianne. "Between Scorching Heat and Freezing Cold: Medieval Jewish Authors on the Inhabited and Uninhabited Parts of the Earth." Arabic Sciences and Philosophy, vol. 10 (2000), 101-137.

Frank, Georgia. The Memory of the Eyes: Pilgrims to Living Saints in Christian Late Antiquity. Berkeley: University of California Press, 2000.

Furdell, Elizabeth Lane. Textual Healing: Essays on Medieval and Early Modern Medicine. Leiden: Brill, 2005.

Gertz, Sebastian and Ramon Philipp. Death and Immortality in Late Neoplatonism: Studies on the Ancient Commentaries on Plato's Phaedo. Leiden: Brill, 2011.

González Manjarrés, Miguel Ángel. "La Ris en la Fisiognomía Antigua y Medieval." Traditio 67 (2012): 305-339.

Grant, A.J. trans. Life of Charlemagne. Cambridge, Ontario: Parentheses Publications, 1999.

Grant, Edward. The Foundations of Modern Science in the Middle Ages: Their Religious, Institutional, and Intellectual Contexts. Cambridge University Press, 1996. 
ed. A Sourcebook in Medieval Science. Cambridge, MA: Harvard University Press, 1974.

Gregg, Robert C., trans. Athanasius: The Life of Saint Anthony. New York: Paulist, 1980.

Gutas, Dimitri. Greek thought, Arabic culture: the Graeco-Arabic translation movement in Baghdad and early 'Abbasid society $\left(8^{\text {th }}-10^{\text {th }}\right.$ centuries). London: Routledge, 1998.

Hamilton, Edith and Huntington Cairns, eds. The Collected Dialogues of Plato. Bollingen Series vol. 71. Princeton University Press, 1961.

Hasse, Dag Nikolaus. Avicenna's De anima in the Latin West: The Formation of a Peripatetic Philosophy of the Soul, 1160-1300. London: Warburg Institute, 2000.

Hernandez Vargas, Jaime. "Dos viejas celestinas y hechiceras en la lírica quevediana: fisonomía y retratos sociales como instrumentos punitivos." La Perinola 19 (2015): 161-180.

Jacquart, Danielle. “La Physiognomie à l'Époque de Frédéric II: Le Traité de Michel Scot.” In M. R. McVaugh and Véronique Pasche, eds., Le scienze alla corte di Federico II. Turnhout: Brepols, 1994.

--------- “Du genre des $<<$ secretes $>>$ dans la médecine médiéval” Micrologus, 14 (2006), 345-357.

King, Peter. "Aquinas On Passions," in Aquinas's Moral Theory: Essays in Honor of Norman Kretzmann. Ed. Scott MacDonald and Eleonore Stump. Ithaca: Cornell University Press, 1999.

Kilbansky, Raymond, Erwin Panofsky, and Fritz Saxl. Saturn and Melancholy: Studies in the History of Natural Philosophy, Religion, and Art. New York: Basic Books, 1964.

Knuuttila, Simo. Emotions in Ancient and Medieval Philosophy. Oxford University Press, 2004.

Konstan, David. "Aristotle on anger and the emotions: the strategies of status" in Yale Classical Studies Volume XXXII: Ancient Anger, Perspectives from Homer to Galen, ed. Susanna Braund and Glenn W. Most. Cambridge: Cambridge University Press, 2003.

Koyré, Alexandre. From the Closed World to the Infinite Universe. Baltimore: Johns Hopkins University Press, 1957. 
Lageriund, Henrik, and Mikko Yrjönsuuri, eds. Emotions and Choice from Boethius to Descartes. Dordrecht: Kluwer Academic Publishers, 2002.

Larrington, Carolyne. "The psychology of emotion and study of the medieval period." Early Medieval Europe 2010 (2): 251-256.

Leighton, Stephen R. "Aristotle and the Emotions" in Essays on Aristotle's Rhetoric ed. Amélie Oksenberg Rorty (Berkeley: University of California Press, 1996).

Leinenweber, John, trans. Pastoral Practice: Books 3 and 4 of the Regula Pastoralis by Saint Gregory the Great. Harrisburg, PA: Trinity Press International, 1998.

Lemay, Richard. Abu Ma'shar and Latin Aristotelianism in the twelfth century: The recovery of Aristotle's natural philosophy through Arabic astrology. Beirut: Catholic Press, 1962.

Lincicum, David. "Philo and the Physiognomic Tradition." Journal for the Study of Judaism, 44 (2013): 57-86.

Lindberg, David C. The Beginnings of Western Science: The European Scientific Tradition in Philosophical, Religious, and Institutional Context, 600 B.C. to A.D. 1450. Chicago: University of Chicago Press, 1992 and 2007.

Lindberg, David C. and Robert S. Westman, eds. Reappraisals of the Scientific Revolution. Cambridge University Press, 1990.

Maclean, Ian. "The Logic of Physiognomy in the Late Renaissance." Early Science and Medince 16, 2011, 275-295.

Maier, Harry O. Picturing Paul in Empire: Imperial Image, Text and Persuasion in Colossians, Ephesians and the Pastoral Epistles. A\&C Black, 2013.

Manzalaoui, Mahmoud. "The Pseudo-Aristotelian "Kitāb Sirr al-asrār". Facts and Problems.” Oriens, 23/24 (1974), 147-257.

Maraval, Pierre, ed. Égérie: Journal de voyage (Itinéraire) et Lettre sur la Béatissime Égérie, trans. Andrew S. Jacobs. Paris: Cerf, 1982.

Mason, Hugh J. “The Metamorphoses of Apuleius and its Greek Sources.” In Latin Fiction, ed. Heinz Hofmann. Routledge, 2004.

Marenbon, John. The Philosophy of Peter Abelard. Cambridge: Cambridge University Press, 1997.

Martin, John Jeffries. "Francesco Casoni and the Rhetorical Forensics of the Body." Journal of Medieval and Early Modern Studies 45:1 (2015): 103-130. 
McGinn, Bernard, ed. Three Treatises on Man: a Cistercian Anthropology. Spencer, MA: Cistercian Publications, 1974.

McGinnis, Jon. Avicenna. Oxford: Oxford University Press, 2010.

Miller, William Ian. Humiliation: And other Essays on Honor, Social Discomfort, and Violence. Ithaca: Cornell University Press, 1993. Chapter 3 used particularly

Mourad, Youssef. La Physiognomie Arabe et le Kitāb al-Firāsa de Fakhr al-Dīn al-Rāzi. Paris: Librarie Orientaliste Paul Geuthner, 1939.

O’Daly, Gerard. Augustine's Philosophy of Mind. London: Duckworth, 1987.

Olsson, J.T. "The world in Arab eyes: A reassessment of the climes in medieval Islamic scholarship," Bulletin of SOAS, 77, 3 (2014): 487-508.

Parsons, Mikeal Carl. Body and Character in Luke and Acts: the Subversion of Physiognomy in Early Christianity. Grand Rapids, MI: Baker Academic, 2006.

Pick, Lucy K. Conflict and coexistence : archbishop Rodrigo and the Muslims and Jews of Medieval Spain. Ann Arbor : University of Michigan, 2004.

Pormann, Peter E. and Emilie Savage-Smith. Medieval Islamic Medicine. Edinburgh University Press, 2007.

Porter, Martin. Windows of the Soul: Physiognomy in European Culture 1470-1780. Oxford: Clarendon Press, 2005.

Porter, Roy, ed. The Cambridge Illustrated History of Medicine. Cambridge University Press, 1996.

Preus, Anthony. "Galen's Criticism of Aristotle's Conception Theory." Journal of the History of Biology, vol. 10, no1 (Apring 1977): 65-85.

Resnick, Irven M., ed. A Companion to Albert the Great: Theology, Philosophy, and the Sciences. Leiden: Brill, 2012.

Ronca, Italo, "The Influence of the Pantegni on William of Conches's Dragmaticaon," in Constantine the African and 'Ali ibn al- 'Abbas al-Magûsî: The Pantegni and realted texts, Charles Burnett and Danielle Jacquart, eds. Leiden: Brill, 1994.

Rosemann, Philipp W. The Story of a Great Medieval Book: Peter Lombard's Sentences. Ontario, Canada: Broadview, 2007.

Rosenwein, Barbara H. Emotional Communities in the Early Middle Ages. Ithaca, NY: Cornell University Press, 2006. 
Schmitt, Charles and Dilwyn Knox. Pseudo-Aristoteles Latinus: a guide to Latin works falsely attributed to Aristotle before 1500. London: The Warburg Institute, 1985.

Schmitt, Charles and W.F. Ryan. Pseudo-Aristotle The Secret of Secrets: Sources and Influences. London: The Warburg Institute, 1982

Senner, Walter, ed. Albertus Magnus : zum Gedenken nach 800 Jahren : neue Zugänge, Aspekte und Perspektiven. Berlin: Akademie Verlag, 2001.

Signori, Gabriela. "Nikolaus Of Flüe († 1487): Physiognomies Of A Late Medieval Ascetic." Church History and Religious Culture 86 (2006), 229-255.

Silano, Giulio, trans. The Sentences. Book 2: On Creation. Toronto: Pontifical Institute of Medieval Studies, 2008.

Siraisi, Nancy G. Medicine and the Italian Universities, 1250-1600. Leiden: Brill, 2001.

-----------. Medieval and Early Renaissance Medicine: An Introduction to Knowledge and Practice. University of Chicago Press, 1990.

-Taddeo Alderotti And His Pupils: Two Generations Of Italian Medical Learning. Princeton University Press, 1981.

Smith, A. Mark. From Sight to Light: The Passage From Ancient To Modern Optics. University of Chicago Press, 2014.

Strickland, Debra Higgs. Saracens, Demons, and Jews: Making Monsters in Medieval Art. Princeton University Press, 2003.

Stouck, Mary-Ann. Medieval Saints. Broadview, 1999.

Swain, Simon, and G.R. Boys-Stones, eds. Seeing the Face, Seeing the Soul: Polemon's Physiognomy From Classical Antiquity to Medieval Islam. Oxford University Press, 2007.

Takahashi, Adam. "Nature, Formative Power and Intellect in the Natural Philosophy of Albert the Great." Early Science and Medicine, 13, no 5, (2008): 451-481.

Thorndike, Lynn. A History of Magic and Experimental Science. New York: Macmillan, 1958.

Tilmann, Sister Jean Paul OP. An Appraisal of the Geographical Works of Albertus Magnus and His Contributions to Geographical Thought. Department of Geography, University of Michigan, Ann Arbor: 1971. 
van der Lugt, Maaike. "The Learned Physician as a Charismatic Healer: Urso of Salerno (Flourished End of Twelfth Century) on Incantations in Medicine, Magic, and Religion." Bulletin of the History of Medicine, 87, no 3 (Fall 2013): 307-346.

Viguera Molíns, María Jesús. Dos cartillas de Fisiognómica. Madrid: Editoria Nacional, 1977.

Wack, Mary Frances. Lovesickness in the Middle Ages: the Viaticum and its Commentaries. Philadelphia: University of Pennsylvania Press, 1990.

Weispheipl, James A, ed. Albertus Magnus and the Sciences: Commemorative Essays 1980. Toronto: Pontifical Institute of Medieval Studies, 1980.

Weiss, Roberto. The Dawn of Humanism in Italy. London: H. K. Lewis, 1947.

Willis, Faith, ed. Medieval Medicine: A Reader, series ed. Paul Edward Dutton, University of Toronto Press, 2010.

Williams, Steven J. Secret of Secrets: The Scholarly Career of a Pseudo-Aristotelian Text in the Latin Middle Ages. Ann Arbor: University of Michigan Press, 2003.

Wopke de Boer, Sander. The Science of the Soul: The Commentary Tradition on Aristotle's De Anima, c. 1260-c. 1360, in Ancient and Medieval Philosophy Series. Leuven: Leuven University Press, 2013.

Ziegler, Joseph. "Philosophy and Physicians on the Scientific Validity of Latin Physiognomy, 1200-1500," Early Science and Medicine 12 (2007): 285-312. 


\section{VITA}

Heather Thornton McRae was born in Denton, Texas. Before attending the University of Missouri, Columbia, she attended Furman University in Greenville, South Carolina, where she earned a Bachelor of Arts in Art in 1998. From 2004-2006 she also attended the University of Hawai'i at Manoa, where she earned a Master of Arts in History. 